\title{
INTERACTION BETWEEN ORAL DISEASES AND OTHER HEALTH-RELATED FACTORS
}

\author{
Ph.D. Thesis \\ Krisztina Kárpáti, DMD
}

\author{
Supervisor: \\ Márta Radnai, DMD, Ph.D., Prof. \\ Zoltán Rakonczay, Ph.D, DSc, Prof. emeritus
}

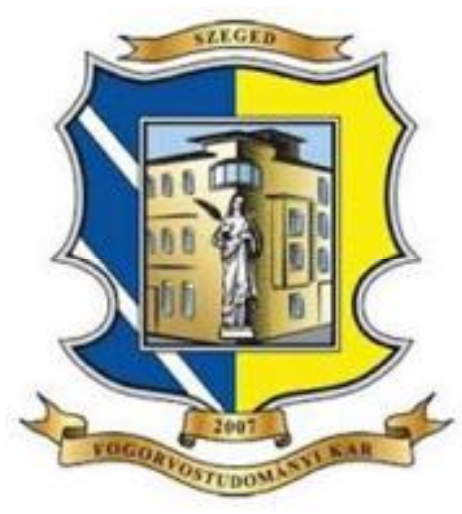

Department of Orthodontics and Pediatric Dentistry

Faculty of Dentistry

University of Szeged

Szeged

2020 
PDF created with pdfFactory Pro trial version www.pdffactory.com 


\section{CONTENTS}

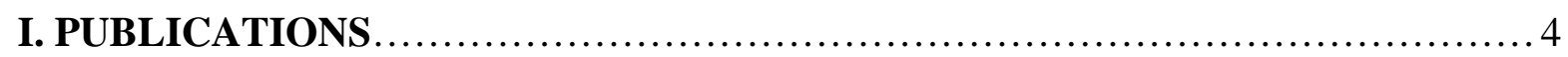

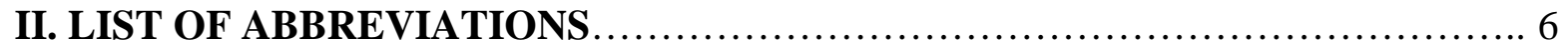

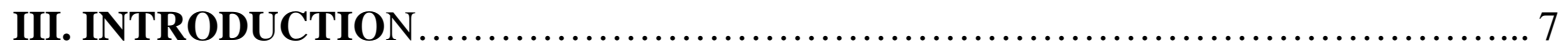

A. The importance of oral health, oral diseases..................................

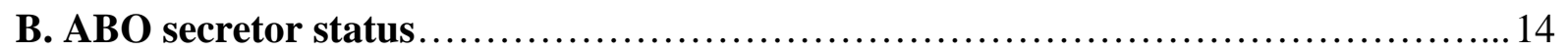

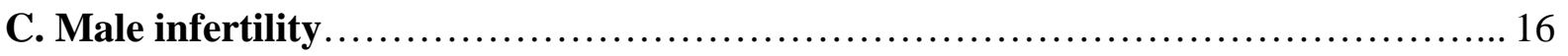

IV. AIMS OF THE STUDY ............................................... 18

V. MATERIALS AND METHODS........................................... 19

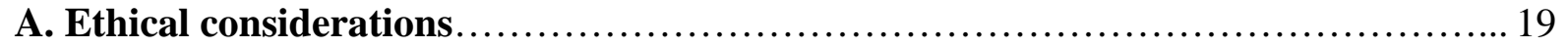

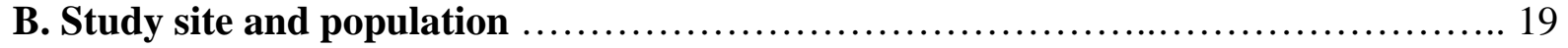

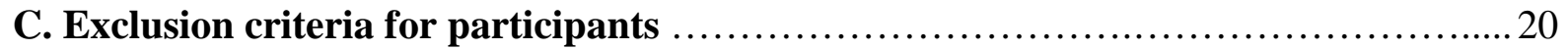

D. Assessment of caries prevalence and oral hygiene .................................. 21

E. Assessment of periodontal status among adult male patients .................... 21

F. Determination of ABO blood groups and secretor status $\ldots \ldots \ldots \ldots \ldots \ldots \ldots \ldots \ldots \ldots \ldots \ldots \ldots \ldots \ldots \ldots$

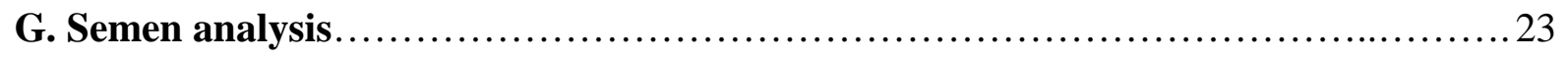

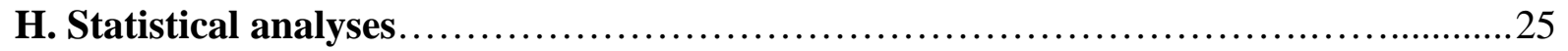

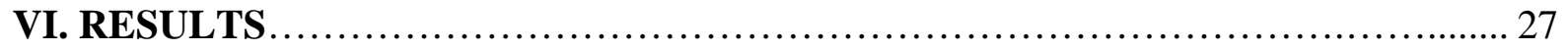

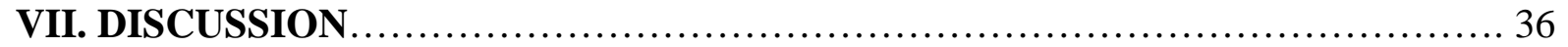

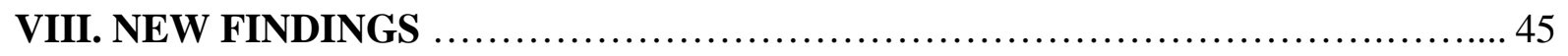

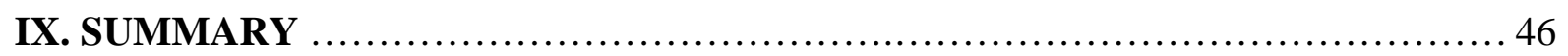

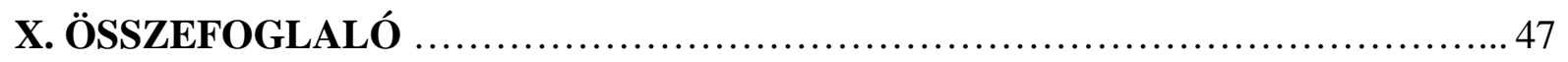

XI. ACKNOWLEDGEMENTS, FINANCIAL SUPPORT ...................... 49

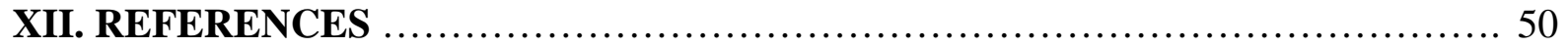

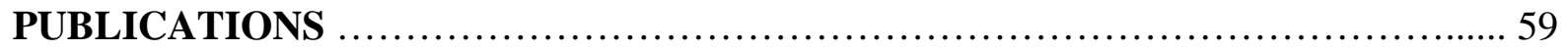




\section{PUBLiCATIONS}

\section{Publications related to the subject of the thesis:}

I. Pásztor N, Kárpáti K, Szöllősi J, Keresztúri M, Kozinszky Z, Gorzó I, Radnai M: Association between periodontal status and idiopathic male infertility. Journal of Oral Science 58(2): 247-253, 2016.

IF $_{2017}: 0.853$, Citations: 2 (Independent citations: 1)

II. Kárpáti K, Braunitzer G, Toldi J, Turzó K, Virág K, Reiche WT, Rakonczay Z, Nagy K: Caries and ABO Secretor Status in a Hungarian Population of Children and Adolescents: An Exploratory Study. Caries Research 48(3): 179-185, 2014.

IF $_{2017}:$ 2.281, Citations: 3 (Independent citations: 3)

$\Sigma$ IF: 3.134

\section{Publications not related to the subject of the thesis:}

I. Reiche W, Párkányi L, Braunitzer G, Nagy K, Kárpáti K: Oligodontia in a Teenager with Down Syndrome - A Case Study. Klinische Padiatrie 227(1): 35-37, 2015.

IF 2015: 0.91, Citations: -

II. Gorzó I, Novák A, Pál E, Battancs E, Kókai E, Kárpáti K, Radnai M. Attitude to oral health habits and awareness of caries prevention methods of expecting mothers in Hungary. Medicine in Evolution 17(3): 269-276, 2011.

IF 2011: -, Citations: -

Cumulative IF: 4.044

Citations: 5 


\section{Presentations related to the subject of the thesis:}

I. Kárpáti K: Vércsoportok és az orális egészség összefüggései. A Magyar Tudomány Ünnepe: Fogorvostudományi Szimpózium "Értékteremtő tudomány". Szeged, Hungary, $21^{\text {th }}$ of October 2019.

II. Kárpáti K: $\mathrm{Az} A B O$ vércsoport antigének nyálba történő expresszálásának hatása a fogszuvasodásra. A Magyar Tudomány Ünnepe: A klinikum és a kutatás összekapcsolása a fogorvoslásban. Szeged, Hungary, $25^{\text {th }}$ of November 2013.

III. Pásztor N, Kárpáti K, Kozinszky Z, Szöllősi J, Radnai M, Pál A: A férfimeddőség és a fogínybetegségek összefüggésének vizsgálata. A Magyar Andrológus Társaság VIII. Kongresszusa. Velence, Hungary, 13-15 ${ }^{\text {th }}$ of November 2014.

IV. Kárpáti K: A vércsoportunktól is függhet, hogy hány szuvas fogunk lesz? SZTE Science Café. Szeged, Hungary, $17^{\text {th }}$ of October 2013.

V. Kárpáti K, Pásztor N, Virág K, Gorzó I, Szöllősi J, Pál A, Radnai M. Oral health status of a Hungarian infertile male population. IADR's $10^{\text {th }}$ World Congress on Preventive Dentistry. Budapest, Hungary, 9-12 ${ }^{\text {th }}$ of October 2013.

VI. Kárpáti K, Toldi J, Turzó K, Rakonczay Z, Nagy K: A szekretor státusz hatása a fogszuvasodásra. Magyar Fogorvosok Egyesülete Árkövi Vándorgyülése. Pécs, Hungary, $20-22^{\text {nd }}$ of September 2012.

VII. Kárpáti K, Toldi J, Turzó K, Rakonczay Z, Nagy K: Az ABO antigének nyálba történő expresszálásának hatása a fogszuvasodásra. MFE Magyar Gyermekfogászati és Fogszabályozási Társaság XXI. Sympozion: V. Tóth Pál Vándorgyülés. Szeged, Hungary, $7-8^{\text {th }}$ of October 2011.

VIII. Kárpáti K, Toldi J, Turzó K, Rakonczay Z, Nagy K: Effect of ABO antigens' expression into saliva on childhood caries. 45th Meeting of the Continental European Division of the International Association for Dental Research (CED-IADR) with the Scandinavian Division. Budapest, Hungary, $31^{\text {st }}$ of August 2011.

Number of presentations related to the subject of the thesis: 8 


\section{LIST OF ABBREVIATIONS}

$\begin{array}{ll}\text { ABGAs: } & \text { ABO group antigens } \\ \text { BOP: } & \text { bleeding on probing } \\ \text { BGI: } & \text { beta-glucuronidase inhibitor } \\ \text { BMI: } & \text { body mass index } \\ \text { CAL: } & \text { clinical attachment loss } \\ \text { CI: } & \text { confidence interval } \\ \text { dmf-t/DMF-T: } & \text { decayed, missing, and filled teeth index } \\ \text { FET: } & \text { Fisher's exact test } \\ \text { EGF: } & \text { epidermal growth factor } \\ \text { GBD: } & \text { Global Burden of Disease } \\ \text { HIV: } & \text { human immunodeficiency virus } \\ \text { ICC: } & \text { intra-class correlation co-efficient } \\ \text { IgA: } & \text { immunoglobulin A } \\ \text { IL: } & \text { interleukin } \\ \text { Le: } & \text { Lewis-antigen } \\ \text { MFI: } & \text { male factors of infertility } \\ \text { MNS: } & \text { mixed, non-secretor } \\ \text { MS: } & \text { mixed, secretor } \\ \text { OHI-S: } & \text { simplified oral health hygiene index } \\ \text { QoL: } & \text { quality of life } \\ \text { PD: } & \text { probing depth } \\ \text { PS: } & \text { permanent, secretor } \\ \text { PNS: } & \text { permanent, non-secretor } \\ \text { Se: } & \text { phenotypic secretor antigen } \\ \text { SPSS: } & \text { Statistical Package for Social Sciences } \\ \text { TNF- } \alpha: & \text { tumor necrosis factor-alpha } \\ \text { TGF- } \boldsymbol{\beta}: & \text { tissue growth factor-beta } \\ \text { WHO: } & \text { World Health Organization } \\ \text { YLD: } & \text { Years Lived with Disability } \\ & \end{array}$




\section{INTRODUCTION}

\section{A. The importance of oral health, oral diseases}

The oral cavity is a complex region of the human body, made up of different types of tissue components, resulting in a complex architecture. By anatomical definition, the oral cavity (rima oris) is the space from the lips till the end of the hard palate [1]. It contains the teeth (dentes), the buccal and gingival mucosa, the mandible (mandibula) and hard palate (palatum durum), the floor of the mouth, and the anterior part of the tongue to the circumvallate papillae [2]. The oral cavity is a multifunctional environment, with important roles in digestion (as a part of the gastro-intestinal tract) and communication [3]. This anatomical region contains the salivary glands; the main product of these glands in the saliva, which is an extracellular fluid, containing $>99 \%$ water, electrolytes, mucin, white blood cells, enzymes relevant in digestion (amylase, lipase) and antimicrobial defense (lysozyme) and other proteins (e.g., secretory IgA, epidermal growth factor [EGF]) [4]. Two general types of salivary glands may be distinguished: serous glands predominantly secrete a watery fluid; while mucous glands secrete a more viscous saliva that contains mucin [4,5]. Changes in the flow rate, chemical composition (e.g., $\mathrm{pH}$, protein content) and viscosity of the saliva are subject to the dynamically changing processes in the human body; it is influenced by age, hydration status, dietary factors, psychological conditions (e.g., anxiety) and various illnesses (e.g., Sjörgen-syndrome) [6,7]. In addition, several pharmacological agents may cause the

lack (i.e. xerostomia, typical examples include tricyclic antidepressants, antipsychotics, atropines, $\beta$-blockers and antihistamines) or excess production (i.e. sialorrhea, the typical example is clozapine) of saliva [6-9].

Oral health is considered as an important indicatior of well-being, quality of life (QoL) and overall health status of persons [10]. The World Health Organization (WHO) defines oral 
health as the following: "a state of being free from chronic mouth and facial pain, oral and throat cancer, oral infection and sores, periodontal (gum) disease, tooth decay, tooth loss, and other diseases and disorders that limit an individual's capacity in biting, chewing, smiling, speaking, and psychosocial wellbeing [11]. The Global Burden of Disease (GBD) Study in 2016 has estimated that diseases affecting the oral cavity impact at least 3.5 billion people worldwide [12,13]. The GBD 2016 Study has identified seven oral diseases and conditions to be accountable for majority of the oral disease burden, these diseases are: dental caries (i.e. tooth decay), periodontal diseases, oral malignancies, oral manifestations of HIV, oro-dental trauma cleft lip and palate, and noma (a rapidly progressive often gangrenous infection of the mouth and face) [12]. A characteristic of all the above mentioned conditions is that there are effective preventive measures against their emergence or that they can be treated effectively in the early stages of the disease [11-13]. In the following subsection, the most prevalent oral diseases and various contributing factors are discussed:

\section{Dental caries (tooth decay)}

Dental caries is a consequence of microbial biofilm (i.e. plaque) formation of the surface of the teeth, converting free sugars from intake food and drink into acidic substances, resulting in the dissolution of the tooth enamel and dentine over a long period. Risk factors for the development of caries include low intake of fluoride, a sugary diet and inappropriate dental hygiene. Caries of the permanent teeth has been shown to be the most prevalent condition (affecting 2.4 billion people), while 486 million children suffer from caries of primary teeth. The consequences of caries include painful cavities, decreased QoL, loss of teeth and systemic infection and inflammation [11-15]. 


\section{Periodontal diseases}

Periodontal diseases are defined by conditions that affect tissues surrounding and supporting the teeth. The clinical presentation of periodontal diseases includes bleeding or swollen gums (gingivitis), pain in the tissue and bad breath (halitosis). Gingivitis is a nondestructive type of periodontal disease; however, untreated gingivitis can progress to periodontitis. Periodontitis is a more severe form of the disease, characterized by the loss of gum attachment to the tooth and supporting bones, causing the formation of "pockets" and loosening of teeth. In severe cases, gingivitis and periodontitis may also lead to tooth loss $[11-13,16,17]$.

In the last several decades, it has been extensively studied that poor dental health can adversely affect a number of systemic conditions and diseases [18,19]. Namely, significant correlation has been found between the emergence of gingivitis and periodontitis and other systemic conditions and diseases, such as cardiovascular diseases [20], diabetes type II [21], respiratory diseases [22], inflammatory bowel diseases [23], and can even lead to preterm delivery $[24,25]$ and other systemic inflammatory diseases [26,27].

\section{Tooth loss}

Previously mentioned dental disorders (caries and periodontal disease) are the principal causes of tooth loss [11-17]. Loss of teeth and edentulism are characteristically seen among older people (over 50 years of age) [28]. Loss of teeth and edentulism is one of the leading causes of Years Lived with Disability (YLD), especially in the ageing population of developed countries [29]. 


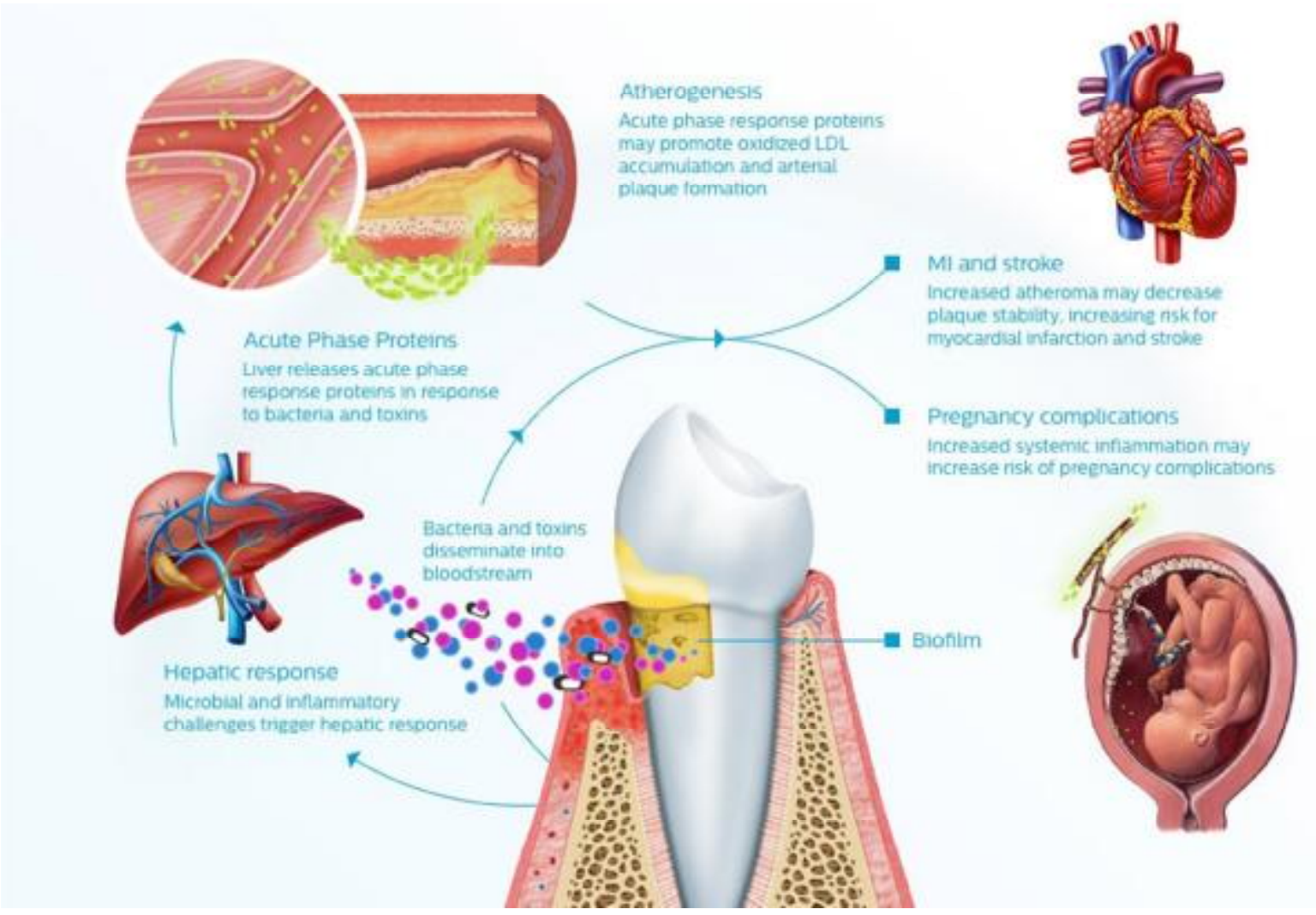

Figure 1. Association between periodontal diseases and systemic health [30]

\section{The oral microbiome}

The oral cavity hosts on the most prominent microbial communities in the human body [31]. The oral microbiome is a complex ecological system, consisting of around 700 different microorganisms (bacteria, viruses, fungi and protozoa), however, it has been suggested that more than $50 \%$ of microorganisms present in the mouth has not yet been cultivated or identified [32]. Typically, there are around 70 types of bacteria that may be consistently found in the mouth, and these bacteria are considered saprophytes, therefore they are not harmful to the host [30,31]. Nevertheless, there are bacteria that have been identified in pathological processes, e.g., Streptococcus mutans in the development of tooth decay [33,34], or various anaerobes, such as Aggregatibacter actinomycentemcomitans, Prevotella intermedia, Porphyromonas ginigvalis, Tannerela forsythia and Treponema denticola in the pathogenesis 
of periodontitis [35]. In general, the disturbance of the qualitative and quantitative composition of the oral microbiota will generally lead to some pathological process in the oral cavity [36-38]. Futhermore, even small changes in this characteristically delicate microflora (i.e. dysbiosis) may affect other organ systems of the body, leading to disease development (Figure 2.) [39], e.g., various types of cancers, autoimmune disorders, psychiatric disorders and some reports even suggested a correlation with the development of autism spectrum disorder and oral dysbiosis [35,40-43].

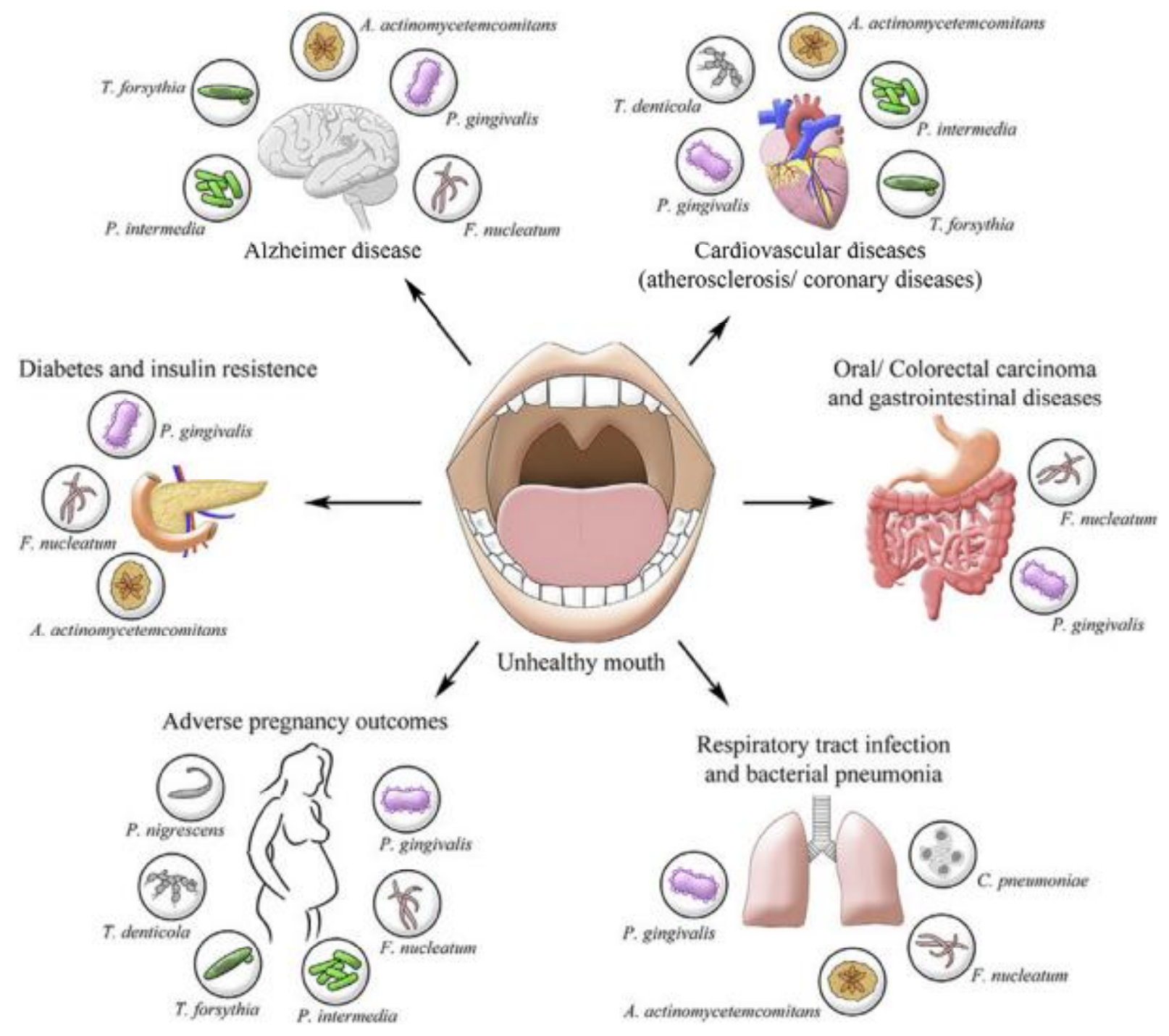

Figure 2. Association between oral dysbiosis (with emphasis on the microorganisms of interest) and various systemic diseases [38] 


\section{Risk factors for oral diseases}

The majority of oral diseases and conditions have similar risk factors; most of these risk factors are modifiable, i.e. they may be managed with appropriate public health interventions $[11-13,44]$. These risk factors include tobacco use, extensive alcohol consumption, diet rich in free sugar, carbohydrates and other unhealthy products, inappropriate fluoride intake, poor access to primary oral healthcare services and poor knowledge and attitudes towards oral selfcare and other social determinants of health $[11-13,44]$. Inequalities in oral health are especially prevalent of low- or middle-income countries (Figures 3-4.) [44]. Possible public health interventions include the promotion of a well-balanced diet (low in free sugars), with an appropriate intake of fruits and vegetables, cessation of smoking and alcohol-consumption, and patient education, e.g., to encourage the use of protective headgear when doing sports and travelling in motor vehicles, as an attempt to reduce the risk of facial injuries $[11-13,44]$.

Nevertheless, it must be noted that some risk factors are biologically/genetically determined (i.e. non-modifiable risk factors) [45], such as advanced age, genetic predisposition (mostly for impaired immune/inflammatory responses), pancreatic diseases and polycystic ovary syndrome [46]. The research activity pertaining to the identification and characterization of these non-modifiable risk factors is a field of extensive research activity in dental science. 


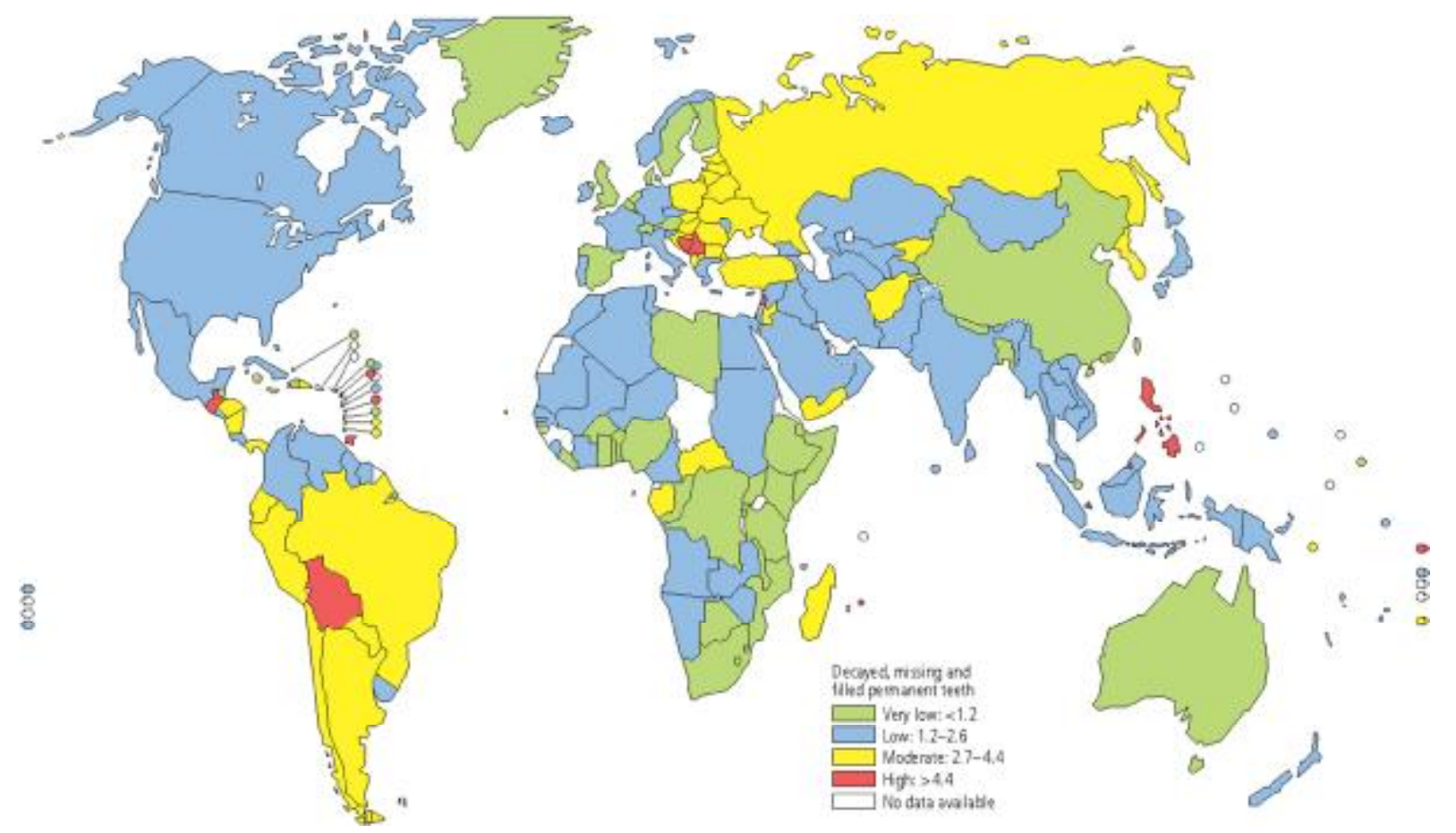

Figure 3. Dental caries levels (based on decayed, missing, and filled teeth [DMF] scores) among 12-year-olds worldwide, December 2004 [44]

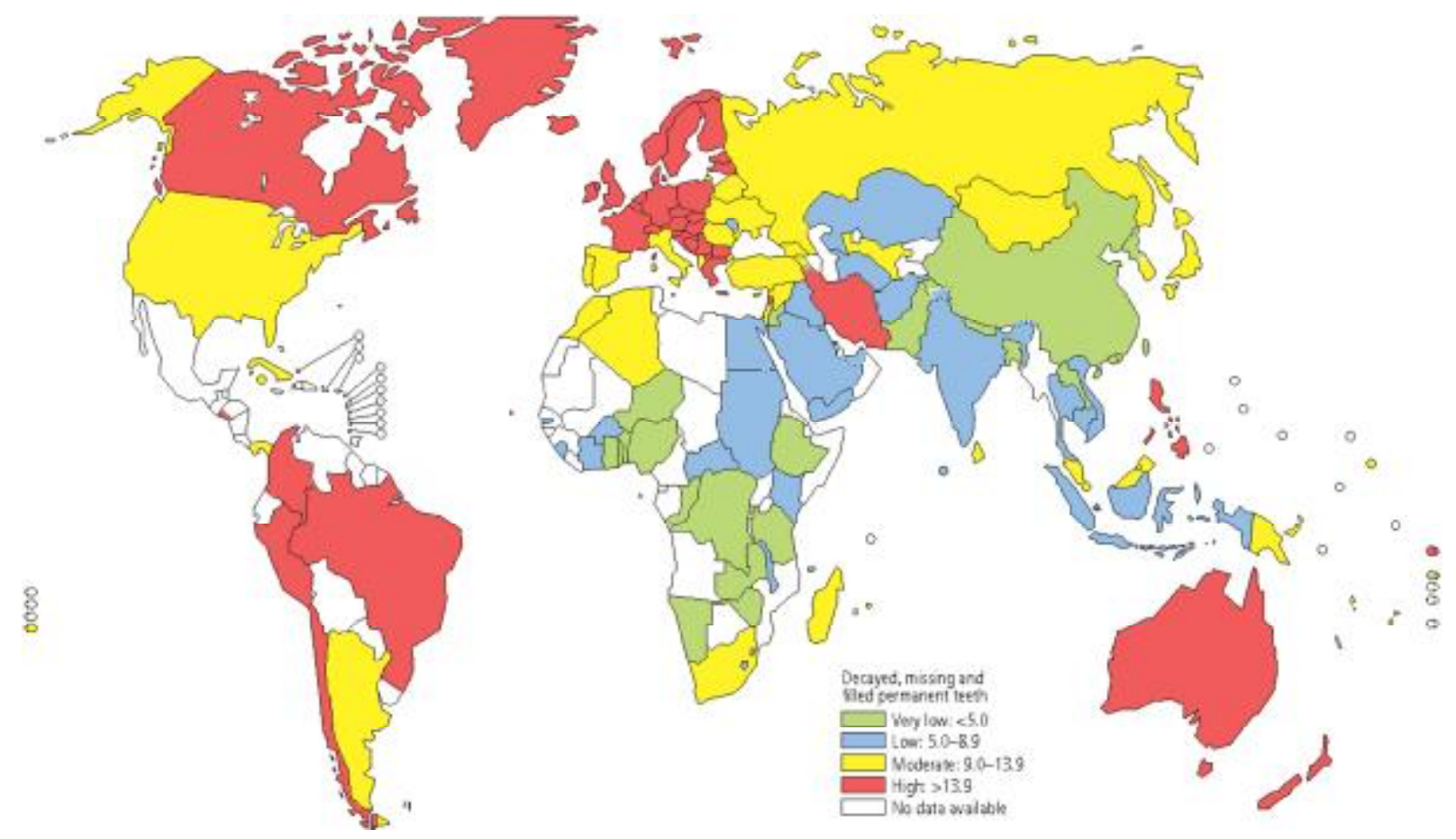

Figure 4. Dental caries levels (based on decayed, missing, and filled teeth [DMF] scores) among 35-44-year-olds worldwide,December 2004 [44] 


\section{B. ABO secretor status}

ABO blood group antigens (ABGAs) are an integral part of the red cell membrane and these antigens are expressed into the body fluids. The classification for these blood group antigens (i.e. the ABO system) was discovered by Landsteiner in 1901 [47]. This classification is based on the modifications of the $\mathrm{H}$-antigen, a carbohydrate sequence, which, when present on the surface of erythrocytes in its unmodified form, codes the O-type. The A, B and AB types are coded by addition of $\alpha-\mathrm{N}$-acetylgalactosamine and $\alpha$-D-galactose to the $\mathrm{H}$-chain (see Figure 5.). About $70-80 \%$ of the population secretes ABGAs in the saliva and other body fluids (e.g., tears, gastric mucosa) where these antigens are bound primarily to mucins $[45,48,49]$. Based on whether an individual secretes ABGAs into body fluids, they may be characterized by socalled "secretor status", between non-secretors and secretors. The secretor status depends on which alleles for the Lewis antigen system the individual carries, that is, an individual carrying the dominant Le and Se alleles will be a secretor [50,51]. The percentage of secretors in Caucasian populations has been estimated to be around 70-80\% [49,52].

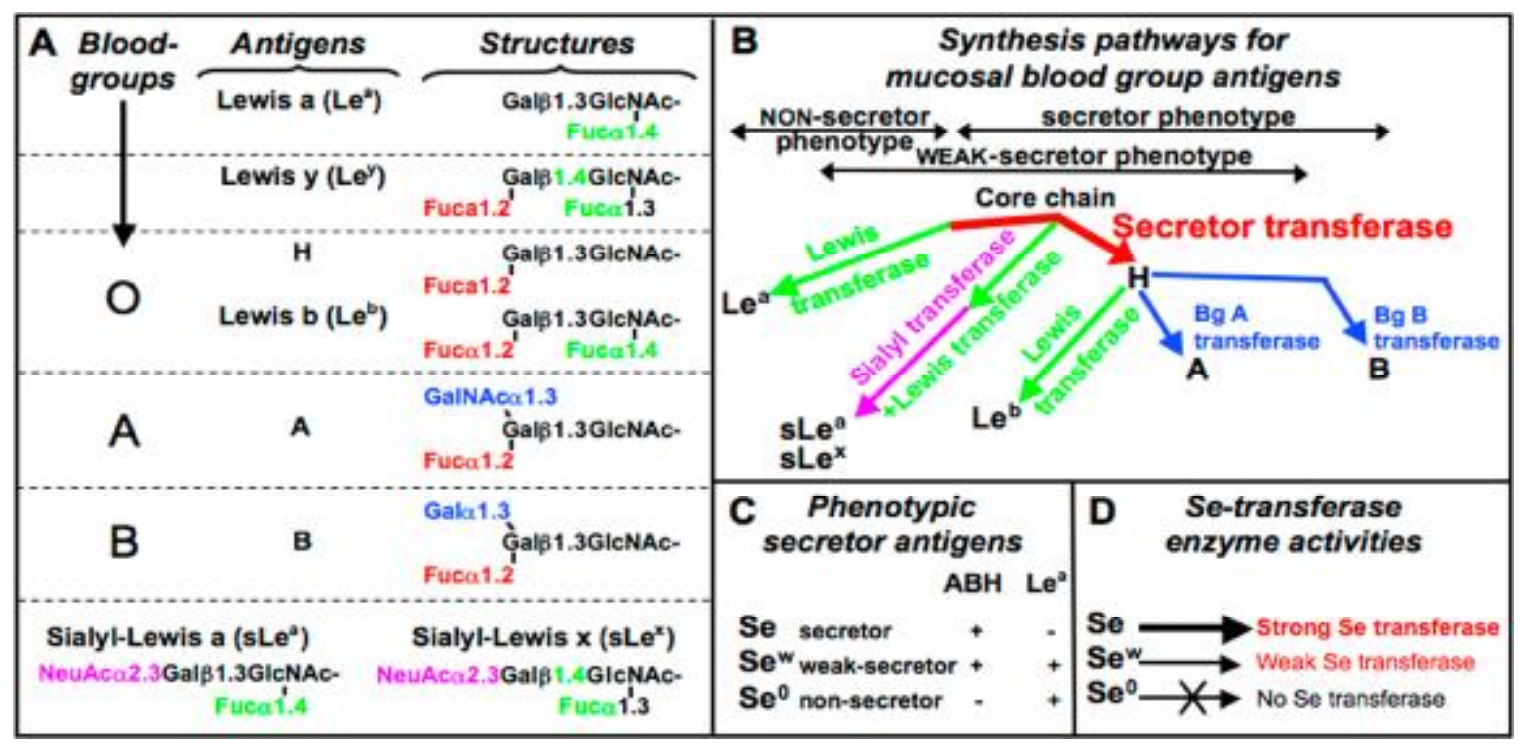

Figure 5. Characterization of fucosylated and sialylated blood group antigens and associated secretor phenotypes [52] 
It has been demonstrated by a number of studies, that the $\mathrm{ABO}$-sector status of a patient may be a possible factor in the etiology and pathogenesis of certain diseases and possibly be an important determinant in oral health [53]. As pointed out by Vidas et al. [45] (which was further explored by various authors in the following years [54-56]), the sector status of a patient may possibly be a factor influencing the development of systemic oral disease. According to Demir et al., the ABO blood groups and the Rh factor may constitute a risk factor in the development of periodontal diseases [57]. The authors found a relatively higher percentage of Group A patients in their gingivitis group and a relatively higher percentage of O group patients in their periodontitis group. However, other studies conducted in different countries, different healthcare settings and in the context of various other illnesses, reached divergent conclusions [54-56]. For instance, it was found that the prevalence of vaginal candidiasis was significantly higher in non-secretors [58]. McGovern et al. found that fucosyltransferase-2 non-secretor status was associated with the development of Crohn's disease [59]. Similarly, Parmar et al. showed association between fucosyltransferase-2 nonsecretor status and celiac disease in the Finnish population [60]. In contrast, Sakamoto et al. found no association between decayed, missing, and filled teeth (DMF) scores and either BGI (beta-glucuronidase inhibitor) activity or secretor status [61]. A seminal Icelandic study suggested that blood group antigens may interfere with the adherence of $S$. mutans to teeth, thereby having a preventive effect against the development of caries [62]. Additionally, a significant positive correlation was observed between DMF scores and BGI-activity in nonsecretors. Nevertheless, other studies revealed a connection between certain other diseases and secretor status, including myocardial infarction [63], neuroses [64], depression [65], retinoblastoma [66], transitional cell carcinoma of the bladder [67], pancreatic cancer [68], gastric cancer [69] and various oral malignancies [70]. 


\section{Male infertility}

Based on the estimation of Kellesarian et al. [71], infertility affects more, than 45 million couples worldwide, which corresponds to a prevalence of $15 \%$ of couples of reproductive age [72]. A considerable societal pressure has been placed on the female population, regarding the burden of subfertility and infertility [73]; however, recent estimates showed that in around $40 \%-50 \%$ of the cases, male factors of infertility (MFI) are (also) responsible for the failure to conceive [74]. Diagnosis of male infertility remains a challenge, as in around one-third of cases, the cause of infertility remains unexplained despite thorough investigation [71,75]. MFI is a multifactorial pathology, associated with many possible risk factors, such as bacteriospermia, urogenital infections, elevated level of reactive oxygen intermediates, endocrine disorders, immunological disorders and genetic determinants [76].

As previously described, periodontal diseases have a significant role in the development of systemic diseases [18,19]. Consequently, the circulation of periodontal pathogens or their metabolic end-products is linked to the development of a widespread inflammatory response in the body, which has been associated with adverse pregnancy outcomes like low birth weight and premature birth [77]. It has also been hypothesized that periodontal disease affects the physiological function of the reproductive system, similar to the way it affects the rest of the body [78]; e.g., the presence of increased levels of IL-6 in the seminal fluid and systemic circulation (as seen in studies of female patients) may be associated with infertility [79]. It has been proposed that periodontal disease may have a possible contributing role to idiopathic pathospermia, reduced sperm quality, subfertility and infertility $[76,80]$. A direct causal relationship was established between bacterial colonies in dental foci and therapy-resistant bacteriospermia (bacteriospermia may be initiated by an infection in the oral cavity that has spread through the blood) [81], in addition, positive 
correlations between deep periodontal pockets and sperm sub-motility have also been demonstrated $[72,76]$. 


\section{AIMS OF THE STUDY}

The aim of my research was to investigate the association of various health-related factors and dental health, specifically corresponding to factors that have not been previously determined in Hungary. During our studies, the association between ABO-secretor status and dental health of younger patients was assessed, to enhance our understanding of this phenomenon with data from with a local context. Similarly, the potential association between the periodontal diseases and pathospermias was scarcely investigated worldwide. In addition, no previous studies have focused on the subgroup of patients with idiopathic male infertility in correlation with periodontal status, hence, the investigation to reveal the potential relationship between periodontal status and spermiogram parameters of men with unexplained infertility was chosen as a second hallmark of this thesis.

The specific goals of the study were the following:

1. Determination of the caries experience and oral hygiene among children and adolescents in Southern Region of Hungary

2. Assessment of potential effects of ABGA expression (i.e. secretor status) into saliva on caries experience among the tested population

3. Seminal analysis of samples from adult male patients with idiopathic male infertility

4. Examination of the potential connection between sperm abnormalities and periodontal status of men with idiopathic male infertility 


\section{MATERIALS AND METHODS}

\section{A. Ethical considerations}

Both study protocols were approved by the Regional and Institutional Human Medical and Biological Research Ethics Committee of the University of Szeged, Hungary (Protocol number: $0420 / 2009$ for the study for children/adolescents and 97/2010 for the examination of adult male patients) and followed the Declaration of Helsinki Ethical Principles for Medical Research (2013). Participants (and the parents in case of children and adolescents) were provided information regarding the goals, risks and the procedures involved in the study in both oral and written form. Upon receiving this information, participants (in case of adult male patients) or the parents of the participants (in case of children and adolescents) were asked to give their consent to the participation by signing voluntarily an informed consent form.

\section{B. Study site and population}

\section{Children and adolescents}

A sample of healthy schoolchildren (including children and adolescents aged between 6-18 years) participated in this study, who presented for an annually organized dental screening. The sample size of this study was determined by the turn-up rate (as annual screening is mandatory in Hungary), willingness to participate and the compliance with the exclusion criteria [82]. The study was carried out at the Department of Pediatric Dentistry and Orthodontics of the Faculty of Dentistry, University of Szeged (Hungary), between $1^{\text {st }}$ of January and $31^{\text {st }}$ of December 2011. 


\section{Adult male patients}

Adult male patients ( $>18$ years of age) seeking infertility evaluation were recruited between $1^{\text {st }}$ of October 2010 and $30^{\text {th }}$ of July 2013. The study site was the Andrology Outpatient Clinic of the Department of Obstetrics and Gynecology, University of Szeged (Hungary). Socio-demographic data (age, place of residence, highest level of education and current profession) and information pertaining to lifestyle factors (body mass index, smoking, alcohol consumption and substance abuse) were collected via a self-administered questionnaire, followed by andrological and periodontal examinations $[83,84]$.

\section{Exclusion criteria for participants}

\section{Children and adolescents}

During the enrollment for this study, only healthy subjects with no existing oral or systemic diseases were eligible for the study. In addition, taking any kind of medications per os at the time of saliva sampling (due to fears of distorting the results) was also a criterion for exclusion from the study [104].

\section{Adult male patients}

Only adult males with idiopathic infertility were enrolled into the study. The following exclusion criteria were defined: varicocele or testicular microlithiasis (confirmed by ultrasound examination); hypogonadism (verified by hormonal measurements); genetic disorders (determined by chromosome analysis or molecular genetic investigations) or symptoms of urogenital infection. Patients with azoospermia (no spermatozoa in the ejaculate) were also excluded due to the possibility of seminal duct obstruction or serious testicular abnormality [84]. 


\section{Assessment of caries prevalence and oral hygiene among children and adolescents}

Data for the calculation of decayed/missing/filled teeth indices (dmf-t/DMF-T) were collected as part of a routine dental status assessment [85]. Caries experience was assessed by calculating the dmf-t/DMF-T scores according to the WHO criteria $[86,87]$. A tooth with more than one carious lesion was scored as one decayed tooth; a tooth with a filling and a separate carious lesion was scored as one filled tooth $[86,87]$. White spot caries lesions were not included, unless probed [88]. The simplified oral health hygiene index (OHI-S) was also calculated, based on the guidelines of Greene and Vermillion [89]. Calculations of OHI-S were carried out, using an operation lamp, mouth mirrors and explorers by the same examiner, prior to the determination of secretor status, therefore, the dentists performing the assessment was blind to subjects' secretor status [90]; thus, a significant potential confounding factor was eliminated.

\section{E. Assessment of periodontal status among adult male patients}

The amount of plaque was recorded on a 0 to 3 scale on the "Ramfjord teeth" $(\# / 16,21,24$, $36,41,44 /)$ at four surfaces per tooth [91], according to the criteria defined by Silness and Löe [92]. If a Ramfjord tooth was missing, the adjacent molar, premolar or central incisor was examined. Probing depth (PD) was measured at six sites of each tooth (mesiobuccal, midbuccal, distobuccal, mesiolingual, midlingual, and distolingual) with the help of a millimeter scale Michigan periodontal probe (Hu-Friedy, Chicago, IL, USA). PD values were recorded in millimeters and were rounded down to the nearest whole millimeter. Sulcus bleeding on probing (BOP) was classified as positive, if bleeding occurred within 15 seconds after probing at any site of the tooth. Dental calculus was recorded dichotomously as present 
or absent. The number of missing teeth was also registered. Poor periodontal status was defined as a probing depth of $\geq 4 \mathrm{~mm}$ at least at one site and BOP at $\geq 50 \%$ of teeth [24]. Repeated periodontal examination was performed in $n=10$ patients and repeated after an interval of 30 minutes, to determine the intra-class correlation co-efficient (ICC), the reliability of measurements for the male patients $[93,94]$. Based on the results of these ten patients, an intra-class correlation co-efficient value of 0.90 was calculated, which indicated good reliability $[93,94]$. Wisdom teeth and radices, where it was impossible to carry out the measurements of the probing depth (PD) were excluded from the periodontal charting. The dental examinations were performed by dentists who were experienced in periodontal charting.

\section{F. Determination of ABO blood groups and secretor status}

ABO secretor status was determined based on the protocol described by Vidas et al. [45]. Unstimulated whole saliva (3-4 mL) was collected from each child/adolescent subject, saliva was collected in test tubes. A glass funnel with a piece of absorbent paper inside was inserted into the test tube and participants were asked to spit into the funnel 1 or 2 times per minute. Using this procedure, it was possible to collect the required amount of saliva. The absorbent paper inside the funnel served to filter contaminants [85,95]. Saliva collection took place either in the morning hours or early in the afternoon, with at least 2 hours passing after the last meal or tooth brushing.

Saliva samples collected were sealed and placed in boiling water for 10-20 minutes to inactivate enzymes. Samples were then centrifuged at $3000 \mathrm{rpm}$ for 5 minutes and the supernatant was separated and analyzed for $\mathrm{ABO}$ blood group antigens (the saliva samples were either processed immediately or stored at $-80^{\circ} \mathrm{C}$ until use) by a hemagglutination inhibition test with appropriate antisera (Blood Grouping Test Reagents Anti-A, Anti-B, Anti- 
H, Sifin ${ }^{\circledR}$ Berlin, Germany; ALBA clone Anti-A, Anti-B, Anti-H Blood Grouping Reagents, Alba Bioscience®, Edinburgh, United Kingdom) [45,96,97].

A plate hemagglutination-inhibition test was employed in the following manner: the saliva samples were diluted in a ratio of $1: 2$, while A-, B-, and $\mathrm{H}$-antisera were diluted in a ratio of 1:8. Sterile distilled water was used for the dilution of saliva and the reagents. The diluted saliva samples and antisera were then mixed in test tubes and stored in a wet chamber for 10 minutes. After the incubation period, 1-2 drops of 2-3\% erythrocyte solution were added to each sample and the result was recorded. The hemagglutination reaction indicated a lack of $\mathrm{ABO}$ antigen production, and a reaction not taking place revealed the presence of antigens in the saliva samples, as in the latter case, the antigen-antibody complexes were already formed when the proper antiserum was added to the saliva sample. In the case of non-secretors, no reaction was seen [98].

The study population was divided into two groups on the basis of dentition (i.e. mixed or permanent, described previously), determined within the secretor and non-secretor subgroups. The mixed dentition group had both deciduous and permanent teeth, the permanent dentition group had permanent teeth only. Data analysis was conducted based on this grouping.

\section{G. Semen analysis}

Semen collected from adult male patients was analyzed and classified according to the criteria of the World Health Organization laboratory manual for the examination and processing of human semen [99]. After 3-5 days of abstinence, semen samples were obtained by masturbation and ejaculation into glass containers in a private room close to the laboratory. The samples were handled at room temperature $\left(22-25^{\circ} \mathrm{C}\right)$. The investigation of the semen began within 1 hour following ejaculation [100]. Sperm concentration, total sperm count, total sperm motility, progressive and non-progressive motility were assessed with phase-contrast 
optics at 200X magnification in a Makler® counting chamber (FertiCAD Kft., Budapest, Hungary) as described in the WHO laboratory manual [99]. Sperm morphology was determined at 1000X magnification with oil immersion after Diff-Quik staining (Diff-Quik Staining Set, Medion Diagnostics AG, Düdingen, Switzerland). Progressive motility was specified as the proportion of actively moving spermatozoa. Non-progressive motility was defined as the percent of moving spermatozoa with an absence of progression. Total motility was defined as the sum of progressive and non-progressive motility [99]. Normozoospermia was attributed to normal ejaculation as defined by the WHO reference values; sperm cell concentration $15 \times 10^{6} / \mathrm{ml}$ or greater; total sperm count $39 \times 10^{6} /$ ejaculate or greater; total motility at least $40 \%$; progressive motility $32 \%$ or greater [99]. Cryptozoospermia was diagnosed when spermatozoa were absent from a fresh preparation, but they could be observed in a centrifuged pellet. Criterion for teratozoospermia was the proportion of sperm cells with normal morphology below 4\%. In case of oligozoospermia (sperm concentration $<15 \times 10^{6} / \mathrm{ml}$ ) or asthenozoospermia (progressive motility $<32 \%$ ), blood samples were taken for measurement of hormone levels and ultrasound examination of the testis was also carried out [75]. In case of sperm concentration of $<1 \times 10^{6} / \mathrm{ml}$, karyotyping and azoospermia factor microdeletion of Y chromosome (AZFa /sY84,86/, AZFb /sY127,134/, AZFc /sY254,255/ regions) screening was also performed.

The dental and parodontal parameters of oligozoospermia, asthenozoospermia, cryptozoospermia and of the sperm pathology group (men with any sperm abnormality) were compared to men with normozoospermia (control group). Patients with oligoasthenozoospermia were considered in both the oligozoospermic and asthenozoospermic groups [84]. No information about the andrological status of the patient was available for the dentist at the time of the dental examination. 


\section{H. Statistical analyses}

1. Correlation between secretor status and parameters of dental health (dmf-t/DMF-T and OHI-S)

The normality of variables was tested using Kolmogorov-Smirnov tests. As our data did not fulfill the criteria of normal distribution, nonparametric Mann-Whitney U tests were used for between-groups comparisons [101]. To determine the degree of association between dmft/DMF-T and OHI-S, the $\chi^{2}$ test was used. Wherever our dataset violated the assumption of the $\chi^{2}$ test (i.e. expected frequencies of at least five), we used Fisher's exact test (FET). The level of statistical significance was set at $p<0.05$. Statistical analyses were performed using the Statistical Package for Social Sciences (SPSS) Software (IBM SPSS Statistics for Windows 17.0, IBM Corp., Armonk, NY, USA). In addition, to assure that the resulting sample size yielded statistically meaningful results, a post-hoc power analysis was also conducted [102]. Post-hoc power analysis for the dmf/DMF comparisons was conducted in G*Power (Universität Kiel, Kiel, Germany).

\section{Correlation between semen health and parameters of dental health}

The normality of variables was tested using Kolmogorov-Smirnov tests, demonstrating that the study samples for our database were not normally distributed [101]. Continuous variables were expressed as mean \pm standard deviation. Univariate comparisons for categorical variables were assessed by $\chi^{2}$ tests. The correlation between sperm parameters and total number of teeth of the participants were determined by Spearman's rank correlations. MannWhitney U tests were used for comparison of continuous variables depending on the casecontrol status (pathospermia vs. normal cases and poor periodontal status vs. healthy 
periodontium). Statistical significance was defined at the two-sided $p=0.05$ level. Odds ratios for continuous variables were evaluated by univariate logistic regression. Odds ratios were adjusted for confounding factors (age, smoking status and body mass index) in multiple logistic regression analyses [103]. Statistical analyses were performed using the Statistical Package for Social Sciences (SPSS) Software (IBM SPSS Statistics for Windows 15.0, IBM Corp., Armonk, NY, USA). 


\section{RESULTS}

\section{A. Study population, demographic characteristics}

\section{Children and adolescents}

Overall, $\mathrm{n}=130$ healthy schoolchildren (including $\mathrm{n}_{\text {male }}=60, \mathrm{n}_{\text {female }}=70$ participants) were enrolled in the study. The participants were all Caucasian from a homogenous socioeconomic background.

\section{Adult male patients}

During the study period, $\mathrm{n}=95$ men were recruited consecutively into the study. The sociodemographic characteristics are summarized in Table 1. The average age of the participants was 35.1 years (range: $23-51$ years). $n=26$ men $(27.4 \%)$ were smokers and $16.8 \%$ of the men were obese $(\mathrm{BMI}>30)$.

\section{B. Reproductive (sperm) health of adult male patients}

Out of the ninety-five participants, $n=36$ (37.9\%) men were considered to have oligozoospermia, $n=27(28.4 \%)$ of patients had asthenozoospermia (including $n=15$ patients, who had both disorders). Cryptozoospermia was diagnosed in $n=15(15.8 \%)$ of cases and $\mathrm{n}=32(33.7 \%)$ of men were normozoospermic. $\mathrm{n}=63(66.3 \%)$ of the patients had at least one type of sperm parameter disorder. In five cases (5.2\%) teratozoospermia was found. 
Table 1. Characteristics of the men with idiopathic male infertility at the Department of Obstetrics and Gynecology, University of Szeged

\begin{tabular}{|c|c|}
\hline Age & $N=95(100 \%)$ \\
\hline Mean & $35.1 \pm 5.7$ years \\
\hline $\begin{array}{l}\text { Minimum and } \\
\text { maximum }\end{array}$ & 23.9 years-52.1 years \\
\hline Place of residence & $N=95(100 \%)$ \\
\hline City & $74(77.9 \%)$ \\
\hline Village & $21(22.1 \%)$ \\
\hline Educational level & $N=95(100 \%)$ \\
\hline Primary school & $1(1.1 \%)$ \\
\hline Technical school & $28(29.5 \%)$ \\
\hline Grammar school & $33(34.7 \%)$ \\
\hline Higher education & $33(34.7 \%)$ \\
\hline Occupation & $N=95(100 \%)$ \\
\hline Unemployed & $2(2.1 \%)$ \\
\hline Manual worker & $41(43.1 \%)$ \\
\hline Other & $23(24.2 \%)$ \\
\hline Intellectual & $29(30.7 \%)$ \\
\hline Smoking & $N=95(100 \%)$ \\
\hline No & $69(72.6 \%)$ \\
\hline Yes & $26(27.4 \%)$ \\
\hline 5 cigarette/day & $10(10.5 \%)$ \\
\hline 10 cigarette/day & $10(10.5 \%)$ \\
\hline 20 cigarette/day & $6(6.3 \%)$ \\
\hline Past smoking & $44(46.3 \%)$ \\
\hline Quit $>5$ yrs ago & $13(13.7)$ \\
\hline BMI & $N=95(100 \%)$ \\
\hline$>30$ & $16(16.8 \%)$ \\
\hline$\leq 30$ & $79(83.2 \%)$ \\
\hline
\end{tabular}

Data are presented by number (n) and percentage rate (\%) 


\section{Dental health and secretor status among children and adolescents}

Detailed basic statistics of dentition and secretor status are given in Table 2., in the following, data were analyzed by dentition type and secretor status. Out of the $n=130$ subjects, $n=95$ (73.0\%) turned out to be secretors, out of which $\mathrm{n}=54(56.8 \%)$ had permanent dentition (mean age: 15.63 years; range: $14-18$ years) and $n=41(43.2 \%)$ had mixed dentition (mean age: 9.86 years; range: $6-13$ years). Of the $n=35(26.9 \%)$ non-secretors, $n=17(48.6 \%)$ had permanent dentition and $\mathrm{n}=18(51.4 \%)$ had mixed dentition. In both dentition types, around 40 percent of the subjects were caries-free (defined as dmf-t/DMF-T=0), however, the ratios were considerably different if secretor status was considered (see Table 2.). The ABO antigen distribution in secretors was also determined from the $n=130$ samples of saliva. The distribution of the examined secretor population overall was as follows: A: $44.2 \%(n=41)$; B: $16.8 \%(n=16) ; A B: 15.8 \%(n=15) ; O: 23.2 \%(n=22)$.

The association between OHI-S and dmf-t/DMF-T in the mixed dentition group was not statistically significant, while in the group with permanent dentition, significant association was found between the these two factors $\left(\chi^{2}(252, N=71)=346.93, p<0.0001\right)$. Significant differences in oral hygiene between the different sexes were found only in the mixed dentition group $\left(\mathrm{n}_{1}=33, \mathrm{n}_{2}=30, U=322, p=0.017\right.$, in Mann-Whitney $\mathrm{U}$ test). Consequently, girls between 6-12 years generally exhibited better oral hygiene measured by the OHI-S index than boys of the same cohort (mean OHI-S indices were 0.83 vs. 1.21 , respectively). In the permanent dentition group, such difference was not observed $\left(\mathrm{n}_{1}=27, \mathrm{n}_{2}=40, U=393, \mathrm{p}=0.061\right.$, in MannWhitney U test). 
Table 2. Basic statistics of participants' dentition and secretor status

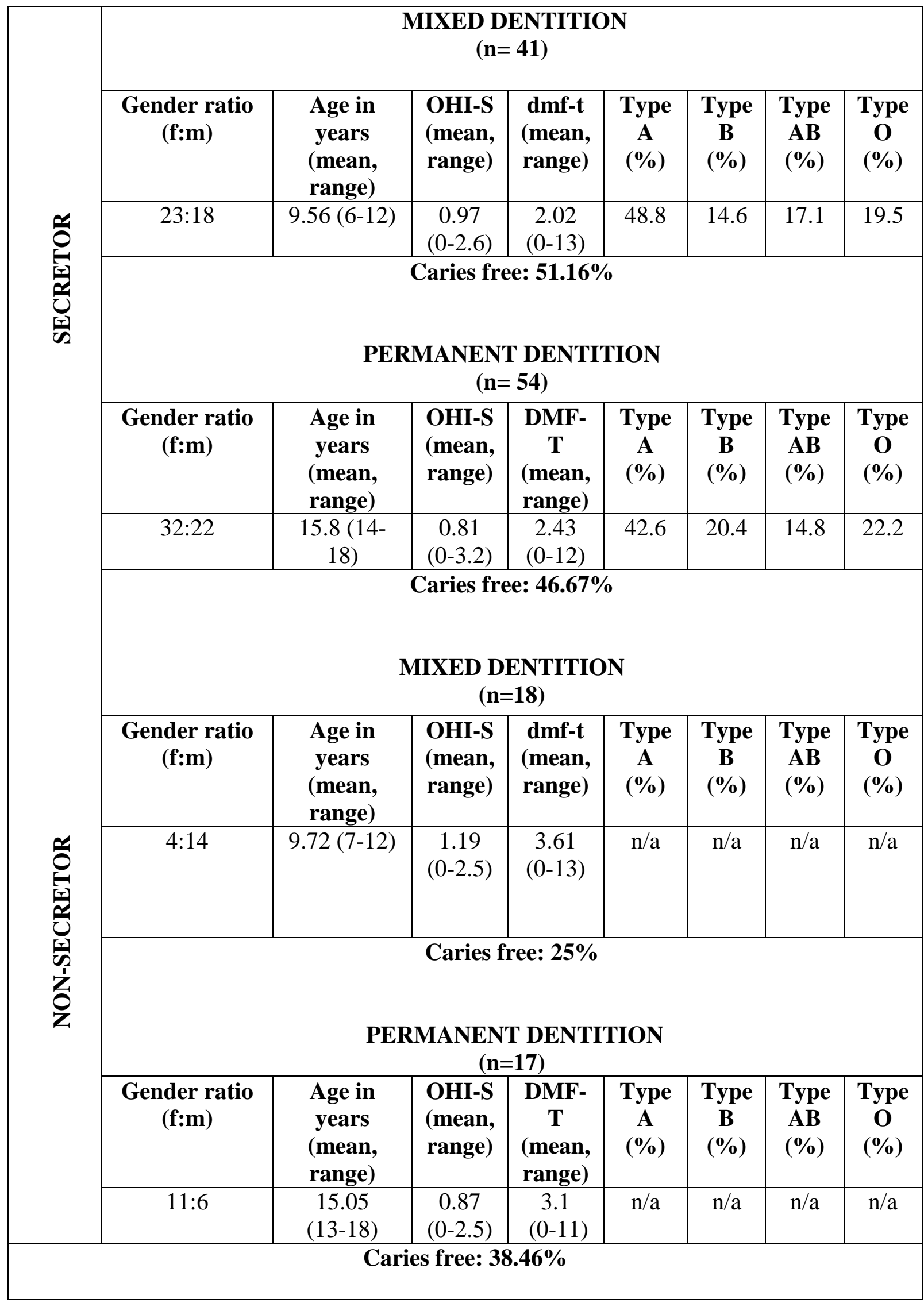


The association between sex and secretor status in mixed dentition was significant $(p<0.0001$, in Fisher's exact test), while in permanent dentition no significant association was found ( $p=0.458$, in Fisher's exact test). To verify that the dmf-t/DMF-T comparisons were not influenced by different oral hygiene as related to sex, OHI-S between the sex subgroups of the secretor/non-secretor groups were also compared. No significant difference was found for either sex (secretors versus non-secretors: [girls: $\mathrm{n}_{1}=54, \mathrm{n}_{2}=15, U=397, p=0.914$, in MannWhitney U test]; [boys: $\mathrm{n}_{1}=39, \mathrm{n}_{2}=20, U=345, p=0.479$, in Mann-Whitney U test].

There were no statistically significant differences in dmf-t/DMF-T status between secretors and non-secretors in permanent dentition $\left(\mathrm{n}_{1}=17, \mathrm{n}_{2}=54, U=454.5, \mathrm{p}=0.952\right.$, in Mann-Whitney U test). However, statistically significant difference was found in dmf-t between secretor and non-secretor statuses in mixed dentition $\left(\mathrm{n}_{1}=18, \mathrm{n}_{2}=41, U=234, \mathrm{p}<0.05\right.$, in Mann-Whitney $\mathrm{U}$ test). To determine whether this effect was linked to any secreted antigen in particular, association between dmf-t/DMF-T status and antigen types was computed, but no significant association was found: $\chi^{2}(30, N=41)=23.16, p=0.809$. A graphical representation of the comparisons is given in Figure 6. In particular, the mean dmf-t/DMF-T values in mixed dentition were significantly lower in the secretor group $(2.1 \pm 3.46)$, compared to the nonsecretor group $(3.8 \pm 3.94)$. When only dentition types were compared without taking secretor status into account, this difference could no longer be observed $(2.60 \pm 3.76,2.59 \pm 3.13$, mixed and permanent, respectively).

Post-hoc power analysis revealed a high statistical power: $1-\beta=0.89(\mathrm{~d}=0.5, \alpha=0.05)$ to our analyses. 


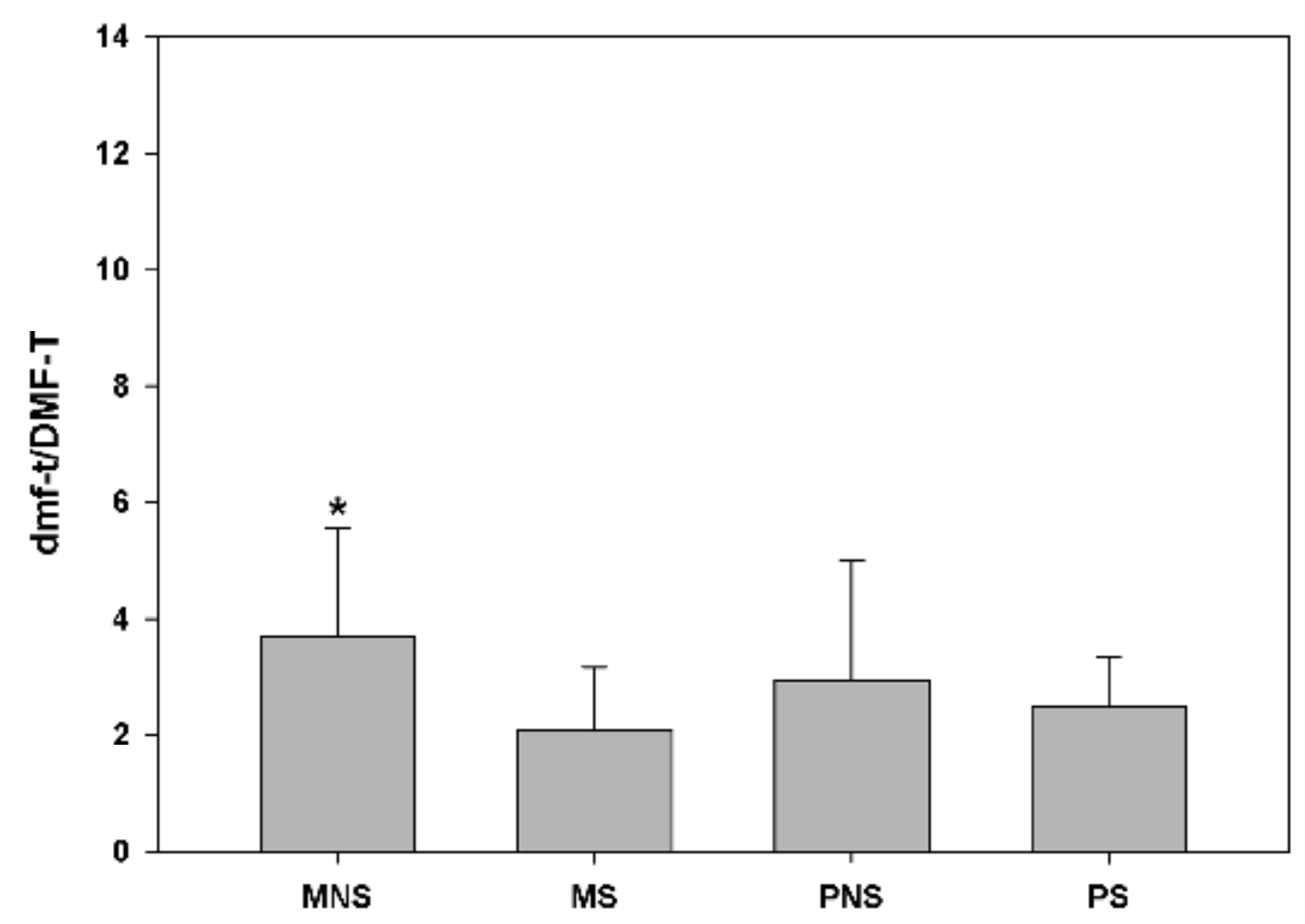

Figure 6. Comparison of dmf-t/DMF-T by dentition type and secretor status. MNS: mixed, non-secretor; MS: mixed, secretor; PNS: permanent, non-secretor; PS: permanent, secretor. Bars denote means, whiskers mark 95\% CI. The asterix denotes significant difference at the level $\mathrm{p}<0.05$.

\section{Periodontal status in the context of spermiograms among adult male patients}

Periodontal examination data of adult male patients were analyzed in the context of the spermiogram groups (based on the laboratory analyses of the collected sperm samples) in Tables 3-4. The mean plaque index was 0.69 in the sperm pathology group, while 0.63 in the control group (defined in the Materials and Methods section). The average PD was $2.19 \mathrm{~mm}$ and BOP occurred at $55.5 \%$ of the teeth among those who had any type of sperm abnormality, whereas these periodontal factors among men with normozoospermia were 1.99 and $53.9 \%$, respectively. Men with spermiogram disorders tended to have a PD $\geq 4 \mathrm{~mm}$ more frequently than the control group, although the difference was not significant $(44 / 69.8 \%$ and $18 / 56.3 \%$, respectively). 62 men had $\geq 4 \mathrm{~mm}$, and $15 \mathrm{men}$ had $\geq 6 \mathrm{~mm}$ probing depths indicating that two- 
thirds of the participants had deep, and almost one-sixth of the patients had very deep periodontal pockets. In addition, the frequency of having poor periodontal status, characterized by having bleeding on probing at $\geq 50 \%$ of the teeth and having at least one $\geq 4 \mathrm{~mm}$ PD at the same time (POB $\geq 50 \%+\mathrm{PD} \geq 4 \mathrm{~mm}$, see Table 3), was practically the same in the sperm pathology group and in the normozoospermia groups $(50.8 \%$ and $50.0 \%$, respectively).

Poor periodontal status (i.e. studied periodontal parameters) did not show any significant association with any of the sperm abnormalities (crypto-, astheno- and oligozoospermia) and did not correlate significantly with any of the sperm parameters, as compared to controls. Teratozoospermia did not exert any significant correlation with the adverse periodontal status (data not shown in tables). Interestingly, men with asthenozoospermia had the lowest BOP per teeth among all subgroups tested. 
Table 3. Dental parameters according to sperm pathologies among men with idiopathic male infertility

\begin{tabular}{|c|c|c|c|c|c|c|c|c|c|c|c|c|c|c|c|c|c|}
\hline & $\begin{array}{c}\text { Crypto- } \\
\text { zoospermia } \\
(n=15)\end{array}$ & $P$ value & $\begin{array}{c}\text { OR } \\
(95 \% \mathrm{CI})\end{array}$ & $\begin{array}{c}\text { AOR } \\
(95 \% \mathrm{CI})\end{array}$ & $\begin{array}{c}\text { Astheno- } \\
\text { zoospermia } \\
(n=27) \\
\end{array}$ & $P$ value & $\begin{array}{c}\text { OR } \\
(95 \% \mathrm{CI})\end{array}$ & $\begin{array}{c}\text { AOR } \\
(95 \% \mathrm{CI})\end{array}$ & $\begin{array}{l}\text { Oligozoo- } \\
\text { spermia } \\
(n=36)\end{array}$ & $P$ value & $\begin{array}{c}\text { OR } \\
(95 \% \mathrm{CI})\end{array}$ & $\begin{array}{c}\text { AOR } \\
(95 \% \mathrm{CI})\end{array}$ & $\begin{array}{l}\text { Any sperm- } \\
\text { pathology } \\
(n=63)\end{array}$ & $P$ value & $\begin{array}{c}\text { OR } \\
(95 \% \mathrm{CI})\end{array}$ & $\begin{array}{c}\text { AOR } \\
(95 \% \mathrm{CI})\end{array}$ & $\begin{array}{c}\text { Normo- } \\
\text { zoospermia } \\
(n=32)\end{array}$ \\
\hline Plaque score & $0.66 \pm 0.40$ & 0.46 & $\begin{array}{c}1.32 \\
(0.39-4.39)\end{array}$ & $\begin{array}{c}2.39 \\
(0.55-10.45)\end{array}$ & $0.59 \pm 0.42$ & 0.79 & $\begin{array}{c}0.85 \\
(0.30-2.46)\end{array}$ & $\begin{array}{c}0.98 \\
(0.31-3.06)\end{array}$ & $0.73 \pm 0.43$ & 0.13 & $\begin{array}{c}1.70 \\
(0.62-4.66)\end{array}$ & $\begin{array}{c}2.03 \\
(0.68-6.12)\end{array}$ & $0.69 \pm 0.42$ & 0.23 & $\begin{array}{c}1.43 \\
(0.56-3.66)\end{array}$ & $\begin{array}{c}1.94 \\
(0.68-5.48)\end{array}$ & $0.59 \pm 0.55$ \\
\hline $\mathrm{PD}(\mathrm{mm})$ & $2.20 \pm 0.63$ & 0.72 & $\begin{array}{c}1.03 \\
(0.37-2.82)\end{array}$ & $\begin{array}{c}1.04 \\
(0.32-3.38)\end{array}$ & $1.96 \pm 0.73$ & 0.11 & $\begin{array}{c}0.58 \\
(0.25-1.32)\end{array}$ & $\begin{array}{c}0.55 \\
(0.23-1.31)\end{array}$ & $1.90 \pm 0.58$ & 0.07 & $\begin{array}{c}0.44 \\
(0.18-1.04)\end{array}$ & $\begin{array}{c}0.39 \\
(0.1-0.98)\end{array}$ & $1.99 \pm 0.68$ & 0.17 & $\begin{array}{c}0.64 \\
(0.33-1.22)\end{array}$ & $\begin{array}{c}0.61 \\
(0.31-1.20)\end{array}$ & $2.19 \pm 0.61$ \\
\hline $\begin{array}{l}\mathrm{PD} \geq 4 \mathrm{~mm} \\
(n(\%))\end{array}$ & $10(66$. & 0.50 & $\begin{array}{c}1.56 \\
(0.43-5.60)\end{array}$ & $\begin{array}{c}2.28 \\
(0.46-11.23)\end{array}$ & (77) & 8 & $\begin{array}{c}2.72 \\
(0.87-8.55)\end{array}$ & $\begin{array}{c}3.07 \\
(0.87-10.91)\end{array}$ & $25(6$ & 26 & $\begin{array}{c}1.77 \\
(0.65-4.78)\end{array}$ & $\begin{array}{c}1.82 \\
(0.64-5.19)\end{array}$ & 44( & 19 & $\begin{array}{c}1.80 \\
(0.75-4.35)\end{array}$ & $\begin{array}{c}1.89 \\
(0.74-4.83)\end{array}$ & 6) \\
\hline $\begin{array}{l}\text { Average number } \\
\text { of } \mathrm{PD} \geq 4 \mathrm{~mm}\end{array}$ & $15.87 \pm 22.41$ & 0.50 & $\begin{array}{c}1.01 \\
(0.98-1.04)\end{array}$ & $\begin{array}{c}1.01 \\
(0.97-1.04)\end{array}$ & $10.56 \pm 21.57$ & 0.98 & $\begin{array}{c}0.99 \\
(0.97-1.02)\end{array}$ & $\begin{array}{c}0.99 \\
(0.96-1.02)\end{array}$ & $7.86 \pm 14.41$ & 0.54 & $\begin{array}{c}0.98 \\
(0.95-1.01)\end{array}$ & $\begin{array}{c}0.97 \\
(0.94-1.01)\end{array}$ & $11.17 \pm$ & 0.66 & $\begin{array}{c}0.99 \\
(0.97-1.01)\end{array}$ & $\begin{array}{c}0.99 \\
(0.97-1.01)\end{array}$ & 13.97 \\
\hline $\begin{array}{l}\text { Frequency of } \\
\text { calculus/teeth }(\%)\end{array}$ & $20.87 \pm 18.71$ & 0.42 & $\begin{array}{c}0.99 \\
(0.96-1.02)\end{array}$ & $\begin{array}{c}0.99 \\
(0.96-1.03)\end{array}$ & $28.87 \pm 26.34$ & 62 & $\begin{array}{c}1.00 \\
(0.98-1.02)\end{array}$ & $\begin{array}{c}1.00 \quad 2 \\
(0.98-1.03)\end{array}$ & $26.29 \pm 20.89$ & 70 & $\begin{array}{c}0.99 \\
(0.98-1.02)\end{array}$ & $\begin{array}{c}1.00 \\
(0.98-1.02)\end{array}$ & $26.85 \pm 22.80$ & .73 & $\begin{array}{c}1.00 \\
(0.98-1.02)\end{array}$ & $\begin{array}{l}1.00 \\
.98-1.02)\end{array}$ & 26.8 \\
\hline $\begin{array}{l}\text { Frequency of } \\
\text { calculus }(n(\%))\end{array}$ & $11(73.3 \%)$ & 0.24 & $\begin{array}{c}0.39 \\
(0.08-1.85)\end{array}$ & $\begin{array}{c}0.49 \\
(0.08-2.98)\end{array}$ & $20(74.1 \%)$ & 0.32 & $\begin{array}{c}0.41 \\
(0.10-1.58)\end{array}$ & $\begin{array}{c}0.49 \\
(0.12-2.04)\end{array}$ & $28(77.8 \%)$ & 0.35 & $\begin{array}{c}0.50 \\
(0.14-1.85)\end{array}$ & $\begin{array}{c}0.61 \\
(0.16-2.36)\end{array}$ & $49(77.8 \%)$ & 0.41 & $\begin{array}{c}0.50 \\
(0.15-1.67)\end{array}$ & $\begin{array}{c}0.61 \\
(0.17-2.13)\end{array}$ & $28(87.5 \%)$ \\
\hline Missing teeth & $3.40 \pm 3.16$ & 0.86 & $\begin{array}{c}1.00 \\
(0.82-1.23)\end{array}$ & $\begin{array}{c}0.90 \\
(0.67-1.22)\end{array}$ & $3.67 \pm 3.04$ & 0.72 & $\begin{array}{c}1.03 \\
(0.87-1.23)\end{array}$ & $\begin{array}{c}0.97 \\
(0.80-1.19)\end{array}$ & $3.78 \pm 3.44$ & 0.76 & $\begin{array}{c}1.04 \\
(0.89-1.21)\end{array}$ & $\begin{array}{c}1.01 \\
(0.84-1.21)\end{array}$ & $3.48 \pm$ & 0.95 & $\begin{array}{c}1.01 \\
(0.88-1.16)\end{array}$ & $\begin{array}{c}0.97 \\
(0.81-1.15)\end{array}$ & 3.38 \\
\hline $\begin{array}{l}\text { Frequency of } \\
\text { BOP/teeth (\%) }\end{array}$ & $17.33 \pm 7.95$ & 0.21 & $\begin{array}{c}1.05 \\
(0.97-1.14)\end{array}$ & $\begin{array}{c}1.04 \\
(0.94-1.14)\end{array}$ & $10.37 \pm 7.73$ & 0.046 & $\begin{array}{c}0.94 \\
(0.88-1.01)\end{array}$ & $\begin{array}{c}0.93 \\
(0.87-1.00)\end{array}$ & $11.69 \pm 7.53$ & 0.14 & $\begin{array}{c}0.96 \\
(0.90-1.02)\end{array}$ & $\begin{array}{c}0.94 \\
(0.88-1.01)\end{array}$ & $13.17 \pm 8.07$ & 0.44 & $\begin{array}{c}0.98 \\
(0.93-1.04)\end{array}$ & 0.97 & $14.22 \pm 8.13$ \\
\hline $\begin{array}{l}\text { Freq } \\
\text { BOP }\end{array}$ & $63.27 \pm 30.89$ & 0.46 & $\begin{array}{r}1.0 \\
(0.99-1\end{array}$ & $\begin{array}{c}1.01 \\
(0.99-1.03)\end{array}$ & $52.04 \pm 29.39$ & 0.57 & $\begin{array}{r}0.9 \\
(0.98-\end{array}$ & $\begin{array}{c}1.00 \\
(0.98-1.01)\end{array}$ & $48.00 \pm 30.43$ & 0.29 & $\begin{array}{r}0 . \\
(0.98\end{array}$ & $\begin{array}{r}0 . \\
(0.98\end{array}$ & $53.90 \pm 30.40$ & 0.74 & $(0.98$ & $\begin{array}{l}1.0 \\
98\end{array}$ & 55.47 \\
\hline $\begin{array}{l}\text { Frequ } \\
>50^{\circ}\end{array}$ & $10(66.7 \%)$ & 1.00 & $\begin{array}{c}1.20 \\
(0.33-4.36)\end{array}$ & $\begin{array}{r}1.1 \\
(0.26-5\end{array}$ & $14(51.9 \%)$ & .44 & $\begin{array}{c}0.65 \\
(0.23-1.83)\end{array}$ & $(0.19)$ & $17(47.2 \%)$ & 23 & $(0.20$ & $(0.1$ & $35(5$ & 0.66 & $(0.3$ & 76) & $5 \%)$ \\
\hline $\begin{array}{l}\text { Frequency of } \\
\text { BOP } \geq 50 \%+\text { PD } \\
\geq 4 \mathrm{~mm}(n(\%))\end{array}$ & $7(46.7 \%)$ & 0.55 & $\begin{array}{c}1.13 \\
(0.33-3.86)\end{array}$ & $\begin{array}{c}1.09 \\
(0.26-4.62)\end{array}$ & $11(40.7 \%)$ & 1.00 & $\begin{array}{c}0.88 \\
(0.31-2.49)\end{array}$ & $\begin{array}{c}0.74 \\
(0.24-2.28)\end{array}$ & $14(38.9 \%)$ & 0.81 & $\begin{array}{c}0.82 \\
(0.31-2.15)\end{array}$ & $\begin{array}{c}0.62 \\
(0.22-1.78)\end{array}$ & $26(41.3 \%)$ & 10.83 & $\begin{array}{c}0.90 \\
(0.38-2.14)\end{array}$ & $\begin{array}{c}0.81 \\
(0.33-2.00)\end{array}$ & $14(43.8 \%)$ \\
\hline
\end{tabular}

All spermpathologies were compared to the normozoospermia group as controls. P-values calculated with Mann-Whitney U probes for continuous variables (expressed as mean \pm standard deviation) and differences between categorical variables (shown by count (n) and percentage rate $(\%))$ were assessed by $\chi^{2}$-tests. Statistical significance was defined at the two-sided $p=0.05$ level. PD: probing depth, BOP: bleeding on probing. 
Table 4. Periodontal status and spermparameters of the patients with idiopathic male infertility at the Department of Obstetrics and Gynecology, University of Szeged

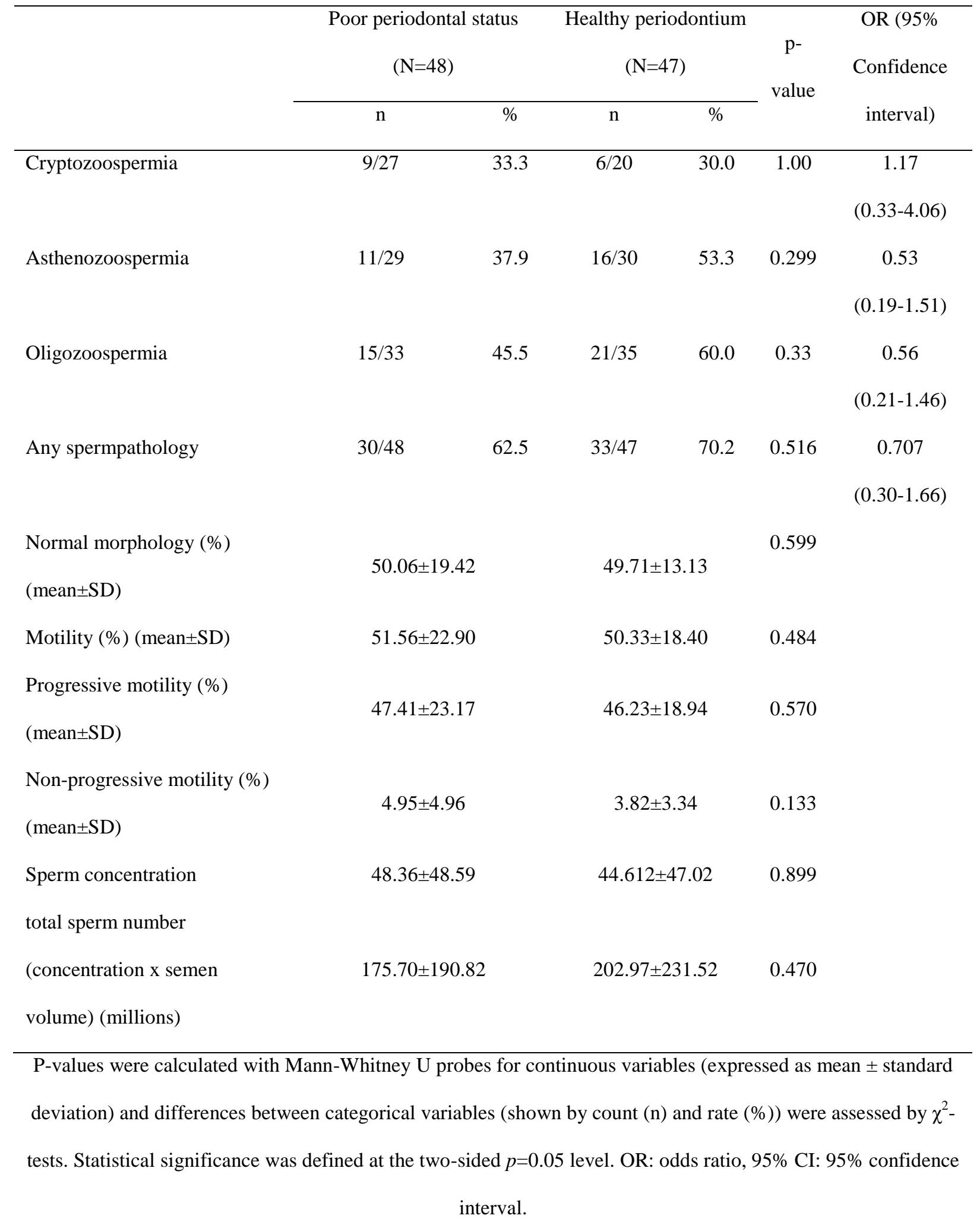




\section{DISCUSSION}

\section{A. Association of dental health and ABO secretor status}

Although association has been suggested with dental health and a number of different diseases, a relatively small number of studies have concerned themselves with the possible association between $\mathrm{ABO}$ secretor status and dental caries in humans, especially in children and adolescents. Mavridis et al. found a higher mean value of DMF-T in secretors, however, the difference was not statistically significant [105]. Barros et al. found no relation between DMF-T and ABO and MN blood groups in a large Chilean population [106], while Arneberg et al. found lower prevalence of caries for secretors, regardless of the blood group, with a more pronounced difference for smooth surfaces (i.e. oral or vestibular tooth surfaces) [48]. In a study corresponding to a young population of Icelanders, Holbrook and Blackwell found significantly lower DMF in secretors than non-secretors [62]. The authors suggested that blood group antigens may interfere with the adherence of $S$. mutans to teeth [62]. It is to be noted that in Iceland, the proportion of non-secretors is among the highest recorded in Europe and the prevalence of caries, especially in childhood, is accordingly high, which seems to be a strong argument for the protective role of ABO secretion against caries [107-109]. Nevertheless, other studies have failed to confirm an association of caries experience and ABO secretion $[62,110,111]$.

In our present study, a sample of 130 children and adolescents were examined in the Southern Region of Hungary, in order to identify if an association exists between caries experience and secretor status. It is important to emphasize that this study-to our knowledge, the first to address this specific issue-was designed as exploratory, and therefore results are to be interpreted as preliminary. Nevertheless, the results of our study may be regarded as an addition to this scientific debate. In terms of the percent-wise distribution of blood types (as 
determined indirectly from antigens secreted into the saliva), our secretor sample was representative of the Hungarian population, as based on previously published reports [112]. The ratio of secretors to non-secretors was also in accordance with previously published data. Caries experience was assessed by the dmf-t/DMF-T scoring system and the simplified oral hygiene index (OHI-S) was also calculated for the study population. The Mann-Whitney U test was used to compare dmf-t/DMF-T and OHI-S between secretors and non-secretors divided into mixed and permanent groups on the basis of dentition. The only significant, secretor status-related difference was found in dmf-t/DMF-T, which was significantly higher in non-secretors, which is one of the main findings of this thesis. Significant difference between sexes was also found in oral hygiene in the mixed dentition group, however, no association was found between dmf-t/DMF-T and OHI-S in either groups. This latter result, counterintuitive as it may seem, is not problematic, because oral hygiene per se is obviously not the only factor influencing caries formation. We assume that OHI-S may be a sensitive predictor of caries status only in poor oral hygiene. Matulaitiene et al. [113] and Milciuviene et al. [114] examined oral health indices of Lithuanian schoolchildren of average to good oral hygiene and reported that while dmf-t/DMF-T decreased significantly in the studied period (1983-2009), OHI-S did not reflect this change [113,114]. The significant difference between different sexes in the younger (mixed dentition) group is also understandable, in light of the superiority of girls over boys in terms of oral hygiene in this cohort [115-117]. As for the significant association between sex and secretor status in mixed dentition, which is lacking in permanent dentition, we have considered this a statistical artifact, possibly stemming from the characteristics of the sample. No publication reporting on such an association has been found in the literature.

The main finding of the abovementioned study, is that $\mathrm{ABO}$ secretors of mixed dentition exhibit lower caries experience, is fairly difficult to explain at the present level of our 
knowledge, especially considering that studies focusing on $\mathrm{ABO}$ secretion and caries in children are limited. Our results, however, show this effect is associated with mixed dentition, that is, the presence of primary teeth. Considering that primary teeth are more caries-prone due to the lower mineral content of their enamel layer $[118,119]$, their morphology $[120,121]$, and narrow interdental spaces [122], it might be hypothesized that secretion of ABO antigens into the saliva may provide some sort of additional protection to primary teeth. In this respect it is important to note that tooth surface was found to be a significant factor in another study dealing with secretor status and caries experience as well [48]. Our findings-especially in view of the Icelandic sample-of course do not necessarily imply that the hypothesised preventive effect is completely missing in adulthood [62,107]. We would argue, rather, that it is more remarkable when the more vulnerable deciduous teeth are still present. The extent of influence of $\mathrm{ABO}$ secretor status on adult dental caries is yet to be determined.

It must be mentioned that both dmf-t/DMF-T and OHI-S scores in the studied population were lower than previously reported in a comparable Hungarian population, and the percentage of caries-free subjects was higher [123-128]. As discussed previously, annual screening is not mandatory in Hungary, therefore, it has been assumed that people attending these screenings (or parents bringing their children) put more emphasis on oral health, which might explain the findings of this study. At the same time, this would suggest that the studied population was not representative of the entire Hungarian population. Nevertheless, this is not necessarily a limitation, as the intent of the study was to describe and assess a biological phenomenon that should be observable regardless of various demographic factors. The exploratory nature of this study, however, raises concerns of whether the observed effect could be due to some uncontrolled background variable, such as dietary or oral hygiene differences between the cohorts. No direct measurements were performed to address such variables, which is obviously a limitation of the study. However, the fact that the significant 
dmf-t/DMFT difference between the dentition types was seen only when secretor status was considered as an influencing factor, allowed for the dismissal of such a scenario. Furthermore, no significant difference in OHI-S (as a measure of oral hygiene) was found between the dentition type-based cohorts (mixed: $2.59 \pm 3.67$ ), permanent: $2.60 \pm 3.13$ ), which makes it quite unlikely that significant changes of oral hygiene habits occurred with age.

As the influence of secretor status on caries experience has been paid surprisingly little attention since the 1970s (when the subject was first mentioned), the exact protective mechanism remains unknown. Based on the literature available, it is possible to set up a reasonable explanatory framework, however, it must be noted that this framework-due to the paucity of research into these mechanisms-can only be speculative in nature. Our proposed explanation focuses on salivary glycoproteins (mucins) and their role in bacterial attachment [129]. We hypothesize that the observed protective effect is due to $A B O$ antigens' interference with the attachment of cariogenic bacteria $S$. mutans to the surface of the teeth. This hypothesis was articulated earlier in connection with $S$. mutans (a major etiological agent of dental caries, whose role is long accepted), however, it must be noted that several other species have been shown to play a role in caries formation and progression $[62,130]$. Williams and Gibbons observed that mucinous glycoproteins could aggregate certain bacterial species and prevent them from attachment to the buccal epithelium [131]. These authors have suggested that this is due to a kind of molecular mimicry, that is, mucinous glycoproteins possessed antigenic determinants in common with a wide range of body cells (including those of the buccal epithelium), and it was these antigenic determinants by which the glycoproteins could aggregate bacteria. More importantly, it was also shown that pre-treatment of epithelial cells from a donor of A blood type with A antiserum prevented the attachment of S. sanguis to these cells. This finding supported the theory that blood group antigens could establish a link between bacteria and the surface on which they are located. However, the study focused on 
the buccal epithelium, not the solid hydroxyapatite surface of teeth, and $S$. mutans was not among the tested species while it was clearly established that the effect was speciesdependent. Furthermore, no testing was performed to establish whether mucin donors were secretors or not, thus the results are best interpreted as characterizing salivary mucins in general. The key finding of their study was the possibly that salivary mucins are able to aggregate bacteria, which, however, is not a really promising finding in terms of caries protection [132]. Mucins are crucial components of the acquired enamel pellicle, without which bacteria could not colonize tooth surfaces and form a complex biofilm, the metabolic processes of which lead to caries, gingivitis and periodontitis $[133,134]$. The acquired pellicle is composed of a variety of salivary glycoproteins and antibodies [135]. This film alters the characteristics of the surface, which in turn increases the efficiency of bacterial adhesion. The aggregation of bacteria by mucins in the enamel pellicle is a pro-carious process, and therefore it cannot account for the protection observed in ABO secretors [136]. ABO antigendeterminants in secretors are located at the terminal part of the carbohydrate side chain in glycoproteins of the mucin type. In other words, the mucins of secretors may be structurally different. We hypothesize that this structural difference might play a key role in the protective effect. Bacteria invade the pellicle-coated enamel surface as primary and secondary colonizers. Primary colonizers (like $S$. mutans) attach directly to the glycoproteins of the acquired pellicle, while secondary colonizers attach to the primary ones. On such premises, two explanations may be suggested. One is that the structural difference of the mucins of secretors deteriorates their ability to aggregate cariogenic bacteria. However, the finding that pre-treatment of mucins with anti-ABO antisera did not influence their ability to aggregate $S$. miteor might be a counterargument here, but by no means an unquestionable one, as the secretor status of mucin donors was not known, and the effect was found to be speciesdependent, even at a very low number of studied species (namely $S$. miteor, $S$. sanguis and $S$. 
salivarius) [131]. This latter finding suggests that the effect of secretor status on mucins shows high inter-species variability [137]. The other explanation may be that structurally altered (secretor) mucins do not adhere so readily and stable to the enamel surface as nonsecretor mucins, therefore, they cannot serve as a firm base for colonization. In any of these two scenarios part of the maximal total bacterial adhesive surface is lost, and S. mutans-based colonization would be less efficient could not take place [138]. This would mean much better but still not perfect caries resistance, as there are several known cariogenic species, and, as mentioned before, the effect appears to be species-dependent [131]. S. mutans is not the only cariogenic species, and possibly not all variants of mucin type glycoproteins exhibit the altered structure described by Marcus et al. [139]. The results of this study and those of other studies suggesting that secretors are better protected but not completely caries-free correspond to such a scenario.

\section{B. Association of dental health and idiopathic male infertility}

In our present study, ninety-five adult males with idiopathic infertility were enrolled to assess any potential interactions between periodontal status and sperm pathologies. Based on our findings, there was no correlation between the poor periodontal status of the participants and any form of idiopathic pathozoospermia in the present study, i.e., poor periodontal status had no significant effect on semen quality. In contrast, previous studies from other authors have demonstrated evidence for a possible connection between periodontal parameters and spermpathologies [76,140]. In the report by Klinger et al. [76], $\mathrm{n}=75$ men were recruited, who were attending an in vitro fertilization clinic. A significant correlation was shown between deep periodontal pockets, clinical attachment loss and sperm submotility. However, there was no difference in periodontal status of men with oligozoospermia and normozoospermia [76]. A similar study was published by Nwhator et al. [140], with the participation of $n=76$ infertile men. In contrast to the results of Klinger et al., Nwhator described a significant association 
between deeper periodontal pockets and suboptimal sperm counts in the 33-38-year-old age group and a correlation between poor oral hygiene and low sperm concentration was also demonstrated [140]. However, in this latter study, no relationship was found between the oral health and sperm motility. Both studies analyzed unselected population regardless of the cause of infertility [76,140], as apparent causes of subfertility were not excluded. Moreover, in these papers, the spermiogram results were categorized by earlier WHO reference values for human semen examination, which has been changed in 2010 [99]. As a consequence, it is difficult to draw relevant conclusions from these conflicting results regarding the connection of chronic periodontitis and male infertility, highlighting the importance of our current study even more.

As the total duration of producing spermatozoa from spermatogonium in humans is around 74 days [141], we did not assess the effects of clinical attachment loss (CAL) in our study. CAL mainly represents previous periodontal processes and can have other, noninfectious causes (e.g., bad tooth brushing technique). On the other hand, not all sites with gingivitis will even develop CAL [142]. Our statistical analyses included the BOP and PD results as main periodontal parameters: this was based on previous studies, because BOP has been proven to be a substantial sign of periodontal inflammation [143-145]. The PD $\geq 4 \mathrm{~mm}$ is considered as a "critical probing depth" size [146], while smaller PD is accepted as normal [147]. Moreover, BOP and PD are considered as significant factors in the risk assessment of recurrence or activity of periodontitis [144]. In our investigation, it seemed to be suitable to record plaque amount on the Ramfjord teeth only, as Löe et al. has shown that plaque is not the solely factor in the progression of chronic periodontitis [148]. In their study, the majority of patients $(81 \%)$ had only moderate progression, despite of poor plaque control and gingival inflammation of each individual member of the study population. Moreover, this partial 
mouth examination is eligible to reduce examination time, which is more convenient for the patients and helps to prevent the fatigue of examiners [149].

Kellesarian et al. proposed two possible mechanisms to explain the association of poor periodontal status and male infertility [71]; the first being that chronic periodontitis can cause an increased bacterial load, resulting in bacteriospermia which could lead to reduced sperm viability and motility. In contrast, the second proposed mechanism implies that the inflammatory cytokines associated with chronic periodontitis cause a chronic systemic inflammatory state, resulting in sperm apoptosis and lower sperm count [71]. Furthermore, in a study performed in 2010, the link between poor oral health in men was found to be associated with sperm count [150]. They have found that oligospermia (low sperm count) and azoopermia (a lack of sperm in the ejaculate) were often present in men with poor oral hygiene. They theorized that TNF- $\alpha$ caused testicular dysfunction, which lead to sperm apoptosis. Overall, further research has to be conducted, in order to confirm the true correlation between periodontal disease and MFI, as well as to establish the extent of the relationship.

There are several lifestyle factors, which may adversely influence periodontal health and andrologic parameters simultaneously, however, smoking is one of the most common harmful habit. It is one of the main risk factors for periodontal diseases and it can also know to have a negative impact of fertility [151]. Tobacco exposure has detrimental effects on sperm production, motility [152,153], and sperm DNA damage as it was demonstrated [154]. In our study population, $27.4 \%$ of patients smoked at the time of enrollment, although there was no significant difference in the proportion of smokers between the study groups. Based on previous results, smoking cessation improves both periodontal health [155] and has beneficial effects on sperm parameters [156], thus patients should be strongly advised to quit smoking. 
Some possible pathomechanisms have emerged as to how periodontal inflammation influences semen quality. In a previous study, correlation was suggested between antibiotic resistant bacteriospermia and the bacterial colonies of dental foci as a result of bacteraemia from the oral cavity [81]. After dental treatment, bacteriospermia was eliminated and the sperm parameters improved compared to the control group. In contrast, later it was demonstrated there was no association between the presence of bacteria in semen and sperm parameters [150]. Hence, in our study plan, bacteriospermia was not investigated. Pathogens can cause remote pathogenic effect not only by direct action via bacteraemia, but also by an elevation in several cytokines in systemic circulation [157]. With the increase in cytokine levels, periodontal disease may trigger C-reactive protein production in the liver $[158,159]$. It is shown that similar inflammatory molecules play an important role in the regulation of blood-testis barrier affecting the function of Sertoli cells, while TNF- $\alpha$, TGF- $\beta$ and IL- 1 can perturb the dynamics of the blood-test barrier [160,161]. In addition, IL-6-levels alternate blood-testis barrier function by inhibiting protein degradation [162]. It is noteworthy, that systemic inflammatory markers are not specific to periodontal disease, as it may reflect inflammation from any and all sources or anatomical regions, it is difficult to determine the contribution of periodontitis. Eberhard et al. [163] found a systemic increase in inflammatory markers, while in contrast, a study by Kinane et al. [164] did not demonstrate a similar correlation between short-term experimentally-induced gingivitis, bacteraemia and systemic cytokine levels. In any case, our results suggest, that gingivitis/periodontitis has no remote effect on sperm production and sperm parameters, as poor oral hygiene showed no relevant relationship with the adverse sperm parameters in idiopathic infertility. The differences between our results and those of previously published [76,140] could vary due to the more strict diagnostic criteria for periodontal conditions and pathospermias observed in our study. 


\section{NEW FINDINGS}

A. Caries experience and oral hygiene among children and adolescents in light of secretor status: In the studied sample, $73.0 \%$ of participants were secretors, around $40 \%$ of participants were caries-free. Girls between 6-12 years exhibited significantly better oral hygiene practices based on the OHI-S measurement in the mixed dentition group. The association between $\mathrm{OHI}-\mathrm{S}$ and dmf-t/DMF-T parameters was only significant in participants with permanent dentition.

B. Assessment of the effects of secretor status on caries experience: There were no statistically significant differences in dmf-t/DMF-T status between secretors and nonsecretors in permanent dentition, a significant protective effect was shown for secretors in mixed dentition. Power analyses releveled a high statistical power for our sample.

C. Seminal analysis of samples from adult male patients with idiopathic male infertility: Out of the ninety-five participants in our sample, $n=63(66.3 \%)$ of the patients had at least one type of sperm parameter disorder detected.

D. Connection between periodontal status and idiopathic male infertility: Poor periodontal status did not show any significant association with any of the sperm abnormalities (crypto-, astheno- and oligozoospermia) and did not correlate significantly with any of the sperm parameters, as compared to controls. Men with asthenozoospermia in our sample had the lowest levels of bleeding on probing ((BOP) among all subgroups. 


\section{SUMMARY}

ABO blood group antigen (ABGA) secretion into the saliva and other body fluids is a well-known phenomenon and there is evidence to suggest a link between secretor status and the appearance of caries. It has been proposed that secretion of these antigens into the saliva might be caries-preventive, however, this proposition is still a matter of debate. $30 \%$ of male infertility cases remain unexplained despite thorough investigation. In previous studies, a positive correlation was found between deep periodontal pockets and sperm sub-motility indicating that periodontitis might have a possible contributing role in idiopathic pathospermia. Our aim was to examine the relationship between caries experience and secretor status in a group of Hungarian children and adolescents, in addition, to evaluate the possible correlation between the periodontal infection parameters and sperm analysis results of men with idiopathic infertility. Altogether 130 children and adolescents participated in the study (aged 6-18 years). Participants were divided into two groups according to dentition (i.e. mixed and permanent). ABGAs were determined from saliva. The DMF-T and dmf-t indices were calculated, as well as OHI-S indices. Association of these indices with secretor status was examined. In mixed dentition, the mean dmf-t values were significantly lower in the secretor group $(2.1 \pm 0.52 \mathrm{SEM})$, as compared to the non-secretor group (3.8 $\pm 0.93 \mathrm{SEM}$; $\mathrm{p}<0.05, \mathrm{MWU})$.

Semen quality and periodontal status of patients were analyzed for 95 otherwise healthy men attended the Andrology Unit for sperm analysis. Half of the patients had poor periodontal status in the sperm pathology and in the normozoospermia groups $(50.8 \%$ and $50 \%$, respectively). $38 \%$ were diagnosed with oligozoospermia, while $28 \%$ had asthenozoospermia, $16 \%$ had cryptozoospermia, while $15 \%$ of cases were classified as normozoospermic. Pathospermia categorization was not a distinguishable factor for the frequency of deep periodontal pockets or calculus. Bleeding on probing tended to be significantly lower in asthenozoospermia compared to normozoospermia. Poor periodontal status did not demonstrate association with any pathospermia categories or with semen pathology parameters.

The finding that children of mixed dentition are apparently better protected against caries suggests that the assumed protective effect might be associated with deciduous teeth; but given the general paucity of knowledge about this topic, further research is indicated. Our findings suggested that pathospermia or poor semen quality was not associated with periodontal infections in men with idiopathic infertility. 


\section{X.ÖSSZEFOGLALÓ}

Az ABO vércsoport-antigén (ABGA) szekréciója a nyálba és más testfolyadékokba közismert jelenség és számos tanulmány utal arra, hogy kapcsolat feltételezhető a szekréciós státusz és a fogszuvasodás prevalenciája között. Egyes tanulmányok szerint antigéneknek nyálba történő kiválasztása protektív lehet a fogszuvasodás kialakulásával szemben, azonban a pontos mechanizmus még mindig vita tárgyát képezi. A férfi meddőség kiváltó oka az esetek kb. 30\%-ában ismeretlen marad az alapos kivizsgálás ellenére. A korábbi vizsgálatokban pozitív korrelációt találtak a fogágybetegségek és a spermiumok motilitása között, jelezvén, hogy a parodontitis esetlegesen hozzájárulhat az idiopátiás patospermiához. Célunk az volt, hogy megvizsgáljuk a caries kialakulása és a szekréciós státusz közötti kapcsolatot gyermek és serdülő populációban, illetve, hogy megvizsgáljuk a parodontitis és az idiopátiás férfi meddőség lehetséges összefüggését sperma analízisen keresztül. Összesen 130 gyermek vagy serdülő (6-18 éves korú) fiatalt vontunk be az első vizsgálatba. A résztvevőket a fogzás szerint két csoportra osztottuk (vegyes és állandó). Az ABGA-státuszt nyálból határoztuk meg. Kiszámítottuk a DMF-T és a dmf-t indexeket, valamint az OHI-S indexet. Megvizsgáltuk ezen indexek caries státusszal való összefüggését. Vegyes fogzásban az átlagos dmf-t értékek szignifikánsan alacsonyabbak voltak a szekréciós csoportban $(2,1 \pm 0,52)$, mint a nem szekretor csoportban $(3,8 \pm 0,93 ; \mathrm{p}<0,05$, MWU). A betegek spermaminőségét és periodontális állapotát $\mathrm{n}=95$ férfi bevonásával elemeztük. A betegek felének rossz parodontális státusza volt a patológiás sperma-paraméterekkel és a normozoospermia csoportban $(50,8 \%$, illetve 50\%). 38\%-nál diagnosztizáltunk oligozoospermiát, 28\%-nál asthenozoospermiát, 16\%-nál kriptozoospermiát, míg az esetek 15\%-a normozoospermiáskéntlett besorolva. A patospermia kategóriák között nem volt megkülönböztethető tényező a parodontális tasakok mélysége vagy a fogkő gyakorisága szempontjából. Az ínyvérzési index szignifikánsan alacsonyabb volt asthenozoospermia esetében, mint a normozoospermiás csoportban. A rossz parodontális állapot nem mutatott összefüggést egyetlen patospermiakategóriával, sem egyetlen patológiás sperma-paraméterrel sem. A vegyes fogzási státuszú gyermekek jelentősen védettnek bizonyultak a szuvasodás ellen, ami arra utal, hogy a feltételezett védőhatás összefüggést mutathat a tejfogakkal; de tekintettel a témával kapcsolatos közlemények általános hiányára, további vizsgálatokra van szükség. Eredményeink arra utaltak, hogy a patospermia vagy az alacsony spermaminőség nem volt 
összefüggésben az idiopáthiás meddőséggel diagnosztizált férfibetegek parodontális státuszával. 


\section{ACKNOWLEDGEMENTS, FINANCIAL SUPPORT}

I would like to thank my supervisor, Prof. Dr. Márta Radnai and Prof. Dr. Zoltán

Rakonczay for the opportunity to work in the research field of my thesis at the Department of Orthodontics and Pediatric Dentistry, Faculty of Dentistry, University of Szeged.

I would like to express my gratitude to Dr. Katalin Nagy and to the head of the faculty, Dr. Zoltán Baráth for the possibility to work in the Faculty of Dentistry, University of Szeged.

The authors would like to express their gratitude to Dr. Krisztina Boda, Dr. Katalin Virág, Dr. Zoltán Kozinszky and to Dr. Gábor Braunitzer for their invaluable contribution concerning the statistical evaluation of the data, and to nurses Zsuzsanna Szél, Krisztina Bella, Mária Kiss Juhászné, Éva Kiss, Lenke Varnyú and Erzsébet Tóth, who assisted with patient management and administration.

I am grateful to Prof. Dr. Michele Shedlin (New York University School of Nursing) and Dr. Márió Gajdács (University of Szeged) for their assistance with the language editing.

This research has been supported by the ETT 248/2009 funded by the Hungarian Ministry of Health. 2009-2011 for 3 year.The effect of ABO blood type antigens and secretor status on dental caries in children.Principal investigator: Prof. Dr. Zoltán Rakonczay. 


\section{E. REFERENCES}

1. Lenz, M.; Greess, H.; Baum, U.; Dobritz, M.; Kersting-Sommerhoff, B. Oropharynx, oral cavity, floor of the mouth: CT and MRI. Eur. J. Radiol. 2000, 33, 203-215.

2. Yousem, D.M.; Chalian, A.A. Oral cavity and pharynx. Radiol. Clin. North Am. 1998, 36, 967-981, vii.

3. van der Bilt, A.; Engelen, L.; Pereira, L.J.; van der Glas, H.W.; Abbink, J.H. Oral physiology and mastication. Physiol. Behav. 2006, 89, 22-27.

4. Dodds, M.W.J.; Johnson, D.A.; Yeh, C.-K. Health benefits of saliva: a review. J. Dent. 2005, 33, 223-233.

5. de Almeida, P.D.V.; Grégio, A.M.T.; Machado, M.A.N.; de Lima, A.A.S.; Azevedo, L.R. Saliva composition and functions: a comprehensive review. J. Contemp. Dent. Pract. 2008, 9, 72-80.

6. Naumova, E.A.; Sandulescu, T.; Bochnig, C.; Khatib, P.A.; Lee, W.-K.; Zimmer, S.; Arnold, W.H. Dynamic changes in saliva after acute mental stress. Sci. Rep. 2014, 4.

7. Xu, F.; Laguna, L.; Sarkar, A. Aging-related changes in quantity and quality of saliva: Where do we stand in our understanding? J. Texture Stud. 2019, 50, 27-35.

8. Wolff, A.; Joshi, R.K.; Ekström, J.; Aframian, D.; Pedersen, A.M.L.; Proctor, G.; Narayana, N.; Villa, A.; Sia, Y.W.; Aliko, A.; et al. A Guide to Medications Inducing Salivary Gland Dysfunction, Xerostomia, and Subjective Sialorrhea: A Systematic Review Sponsored by the World Workshop on Oral Medicine VI. Drugs RD 2017, 17, 128.

9. Gajdács, M. The Concept of an Ideal Antibiotic: Implications for Drug Design. Molecules 2019, 24, 892.

10. Baiju, R.; Peter, E.; Varghese, N.; Sivaram, R. Oral Health and Quality of Life: Current Concepts. J. Clin. Diagn. Res. JCDR 2017, 11, ZE21-ZE26.

11. Oral health Available online: https://www.who.int/news-room/fact-sheets/detail/oralhealth (accessed on Mar 15, 2020).

12. Dye, B.A. The Global Burden of Oral Disease: Research and Public Health Significance. J. Dent. Res. 2017, 96, 361-363.

13. Greenspan, D. Oral health is global health. J. Dent. Res. 2007, 86, 485.

14. Yazdanian, M.; Armoon, B.; Noroozi, A.; Mohammadi, R.; Bayat, A.-H.; Ahounbar, E.; Higgs, P.; Nasab, H.S.; Bayani, A.; Hemmat, M. Dental caries and periodontal disease among people who use drugs: a systematic review and meta-analysis. BMC Oral Health 2020, $20,44$.

15. Selwitz, R.H.; Ismail, A.I.; Pitts, N.B. Dental caries. The Lancet 2007, 369, 51-59.

16. Lang, N.P.; Bartold, P.M. Periodontal health. J. Clin. Periodontol. 2018, 45, S9-S16.

17. Di Benedetto, A.; Gigante, I.; Colucci, S.; Grano, M. Periodontal Disease: Linking the Primary Inflammation to Bone Loss Available online: https://www.hindawi.com/journals/jir/2013/503754/ (accessed on Mar 15, 2020).

18. Eke, P.I.; Dye, B.A.; Wei, L.; Thornton-Evans, G.O.; Genco, R.J.; CDC Periodontal Disease Surveillance workgroup: James Beck (University of North Carolina, Chapel Hill, USA), Gordon Douglass (Past President, American Academy of Periodontology), Roy Page (University of Washin Prevalence of periodontitis in adults in the United States: 2009 and 2010. J. Dent. Res. 2012, 91, 914-920.

19. Albandar, J.M.; Rams, T.E. Global epidemiology of periodontal diseases: an overview. Periodontol. 2000 2002, 29, 7-10.

20. Kebschull, M.; Demmer, R.T.; Papapanou, P.N. "Gum Bug, Leave My Heart Alone!”Epidemiologic and Mechanistic Evidence Linking Periodontal Infections and Atherosclerosis. J. Dent. Res. 2010, 89, 879-902. 
21. Saremi, A.; Nelson, R.G.; Tulloch-Reid, M.; Hanson, R.L.; Sievers, M.L.; Taylor, G.W.; Shlossman, M.; Bennett, P.H.; Genco, R.; Knowler, W.C. Periodontal Disease and Mortality in Type 2 Diabetes. Diabetes Care 2005, 28, 27-32.

22. Azarpazhooh, A.; Leake, J.L. Systematic review of the association between respiratory diseases and oral health. J. Periodontol. 2006, 77, 1465-1482.

23. Vavricka, S.R.; Manser, C.N.; Hediger, S.; Vögelin, M.; Scharl, M.; Biedermann, L.; Rogler, S.; Seibold, F.; Sanderink, R.; Attin, T.; et al. Periodontitis and gingivitis in inflammatory bowel disease: a case-control study. Inflamm. Bowel Dis. 2013, 19, 27682777.

24. Radnai, M.; Gorzó, I.; Urbán, E.; Eller, J.; Novák, T.; Pál, A. Possible association between mother's periodontal status and preterm delivery. J. Clin. Periodontol. 2006, 33, 791-796.

25. Chambrone, L.; Guglielmetti, M.R.; Pannuti, C.M.; Chambrone, L.A. Evidence grade associating periodontitis to preterm birth and/or low birth weight: I. A systematic review of prospective cohort studies. J. Clin. Periodontol. 2011, 38, 795-808.

26. Seymour, G.J.; Ford, P.J.; Cullinan, M.P.; Leishman, S.; Yamazaki, K. Relationship between periodontal infections and systemic disease. Clin. Microbiol. Infect. Off. Publ. Eur. Soc. Clin. Microbiol. Infect. Dis. 2007, 13 Suppl 4, 3-10.

27. Otomo-Corgel, J.; Pucher, J.J.; Rethman, M.P.; Reynolds, M.A. State of the science: chronic periodontitis and systemic health. J. Evid.-Based Dent. Pract. 2012, 12, 20-28.

28. Emami, E.; de Souza, R.F.; Kabawat, M.; Feine, J.S. The Impact of Edentulism on Oral and General Health. Int. J. Dent. 2013, 2013.

29. Peltzer, K.; Hewlett, S.; Yawson, A.E.; Moynihan, P.; Preet, R.; Wu, F.; Guo, G.; Arokiasamy, P.; Snodgrass, J.J.; Chatterji, S.; et al. Prevalence of loss of all teeth (edentulism) and associated factors in older adults in China, Ghana, India, Mexico, Russia and South Africa. Int. J. Environ. Res. Public. Health 2014, 11, 11308-11324.

30. Oral health and the connected body: Periodontal disease. Available online: https://www.usa.philips.com/c-m-pe/dental-professionals/dental_indications/oral-andoverall-health/periodontal-disease [Accessed: 2020.03.29.]

31. Dewhirst, F.E.; Chen, T.; Izard, J.; Paster, B.J.; Tanner, A.C.R.; Yu, W.-H.; Lakshmanan, A.; Wade, W.G. The Human Oral Microbiome. J. Bacteriol. 2010, 192, 5002-5017.

32. Lu, M.; Xuan, S.; Wang, Z. Oral microbiota: A new view of body health. Food Sci. Hum. Wellness 2019, 8, 8-15.

33. Loesche, W.J. Microbiology of Dental Decay and Periodontal Disease. In Medical Microbiology; Baron, S., Ed.; University of Texas Medical Branch at Galveston: Galveston (TX), 1996 ISBN 978-0-9631172-1-2.

34. Loesche, W.J. Role of Streptococcus mutans in human dental decay. Microbiol. Rev. 1986, 50, 353-380.

35. Chen, C.; Hemme, C.; Beleno, J.; Shi, Z.J.; Ning, D.; Qin, Y.; Tu, Q.; Jorgensen, M.; He, Z.; Wu, L.; et al. Oral microbiota of periodontal health and disease and their changes after nonsurgical periodontal therapy. ISME J. 2018, 12, 1210-1224.

36. Gajdács, M.; Urbán, E.; Terhes, G. Microbiological and Clinical Aspects of Cervicofacial Actinomyces Infections: An Overview. Dent. J. 2019, 7.

37. Gajdács, M.; Urbán, E. The relevance of anaerobic bacteria in brain abscesses: a ten-year retrospective analysis (2008-2017). Infect Lond.

38. Bui, F.Q.; Almeida-da-Silva, C.L.C.; Huynh, B.; Trinh, A.; Liu, J.; Woodward, J.; Asadi, H.; Ojcius, D.M. Association between periodontal pathogens and systemic disease. Biomed. J. 2019, 42, 27-35.

39. Sudhakara, P.; Gupta, A.; Bhardwaj, A.; Wilson, A. Oral Dysbiotic Communities and Their Implications in Systemic Diseases. Dent. J. 2018, 6. 
40. Olsen, I.; Hicks, S.D. Oral microbiota and autism spectrum disorder (ASD). J. Oral Microbiol. 2020, 12, 1702806.

41. Minty, M.; Canceil, T.; Serino, M.; Burcelin, R.; Tercé, F.; Blasco-Baque, V. Oral microbiota-induced periodontitis: a new risk factor of metabolic diseases. Rev. Endocr. Metab. Disord. 2019, 20, 449-459.

42. Baker, J.L.; Edlund, A. Exploiting the Oral Microbiome to Prevent Tooth Decay: Has Evolution Already Provided the Best Tools? Front. Microbiol. 2019, 9.

43. Gajdács, M.; Spengler, G.; Urbán, E. Identification and Antimicrobial Susceptibility Testing of Anaerobic Bacteria: Rubik's Cube of Clinical Microbiology? Antibiot. Basel Switz. 2017, 6.

44. Petersen, P.E.; Bourgeois, D.; Ogawa, H.; Estupinan-Day, S.; Ndiaye, C. The global burden of oral diseases and risks to oral health. Bull. World Health Organ. 2005, 83, 661669.

45. Vidas, I.; Delajlija, M.; Temmer-Vuksan, B.; Stipetić-Mravak, M.; Cindrić, N.; Maricíć, D. Examining the secretor status in the saliva of patients with oral pre-cancerous lesions. J. Oral Rehabil. 1999, 26, 177-182.

46. AlJehani, Y.A. Risk Factors of Periodontal Disease: Review of the Literature Available online: https://www.hindawi.com/journals/ijd/2014/182513/ (accessed on Mar 15, 2020).

47. Schwarz, H.P.; Dorner, F. Karl landsteiner and his major contributions to haematology. Br. J. Haematol. 2003, 121, 556-565.

48. Arneberg, P.; Kornstad, L.; Nordbö, H.; Gjermo, P. Less dental caries among secretors than among non-secretors of blood group substance. Scand. J. Dent. Res. 1976, 84, 362366.

49. Wolf, R.O.; Taylor, L.L. THE CONCENTRATION OF BLOOD-GROUP SUBSTANCE IN THE PAROTID, SUBLINGUAL, AND SUBMAXILLARY SALIVAS. J. Dent. Res. 1964, 43, 272-275.

50. Grubb, R. Correlation between Lewis Blood Group and Secretor Character in Man. Nature 1948, 162, 933-933.

51. Simmons, R.T.; Semple, N.M.; Graydon, J.J. The Lewis (Lea) blood group and secretor types. A review; their correlation in the blood and saliva of white Australians. Med. J. Aust. 1951, 1, 105-110.

52. Lindén, S.; Mahdavi, J.; Semino-Mora, C.; Olsen, C.; Carlstedt, I.; Borén, T.; Dubois, A. Role of ABO Secretor Status in Mucosal Innate Immunity and H. pylori Infection. PLOS Pathog. 2008, 4, e2.

53. Vivek, S.; Jain, J.; Simon, S.P.; Battur, H.; Supreetha, S.; Haridas, R. Association of ABO Blood Group and $\mathrm{Rh}$ factor with Periodontal Disease in a Population of Virajpet, Karnataka: A Cross-Sectional Study. J. Int. Oral Health JIOH 2013, 5, 30-34.

54. Pai, G.P.; Dayakar, M.M.; Shaila, M.; Dayakar, A. Correlation between "ABO" blood group phenotypes and periodontal disease: Prevalence in south Kanara district, Karnataka state, India. J. Indian Soc. Periodontol. 2012, 16, 519-523.

55. Koregol, A.C.; Raghavendra, M.; Nainegali, S.; Kalburgi, N.; Varma, S. ABO blood groups and Rhesus factor: An exploring link to periodontal diseases. Indian J. Dent. Res. 2010, 21,364 .

56. Gautam, A.; Mittal, N.; Singh, T.B.; Srivastava, R.; Verma, P.K. Correlation of ABO blood group phenotype and rhesus factor with periodontal disease: An observational study. Contemp. Clin. Dent. 2017, 8, 253.

57. Demir, T.; Tezel, A.; Orbak, R.; Eltas, A.; Kara, C.; Kavrut, F. The Effect of ABO Blood Types on Periodontal Status Eur. J.Dent. 2007,1,139-143

58. Kulkarni, D.G.; Venkatesh, D. Non-secretor status; a predisposing factor for vaginal candidiasis. Indian J. Physiol. Pharmacol. 2004, 48, 225-229. 
59. McGovern, D.P.B.; Jones, M.R.; Taylor, K.D.; Marciante, K.; Yan, X.; Dubinsky, M.; Ippoliti, A.; Vasiliauskas, E.; Berel, D.; Derkowski, C.; et al. Fucosyltransferase 2 (FUT2) non-secretor status is associated with Crohn's disease. Hum. Mol. Genet. 2010, 19, 34683476.

60. Parmar, A.S.; Alakulppi, N.; Paavola-Sakki, P.; Kurppa, K.; Halme, L.; Färkkilä, M.; Turunen, U.; Lappalainen, M.; Kontula, K.; Kaukinen, K.; et al. Association study of FUT2 (rs601338) with celiac disease and inflammatory bowel disease in the Finnish population. Tissue Antigens 2012, 80, 488-493.

61. Sakamoto, W.; Nishikaze, O.; Sugimura, T. beta-Glucuronidase inhibitor-activity in human saliva and its relation to dental caries, secretor status and blood group. Arch. Oral Biol. 1976, 21, 761-763.

62. Holbrook, W.P.; Blackwell, C.C. Secretor status and dental caries in Iceland. FEMS Microbiol. Immunol. 1989, 1, 397-399.

63. Nydegger, U.E.; Wuillemin, W.A.; Julmy, F.; Meyer, B.J.; Carrel, T.P. Association of ABO histo-blood group B allele with myocardial infarction. Eur. J. Immunogenetics Off. J. Br. Soc. Histocompat. Immunogenetics 2003, 30, 201-206.

64. McKeon, J.P.; McColl, D. ABO blood groups in obsessional illness--state and trait. Acta Psychiatr. Scand. 1982, 65, 74-78.

65. Song, C.; Leng, J.; Wang, L.; Li, W.; Zhang, S.; Wang, W.; Liu, P.; Zhang, J.; Xie, B.; Li, $\mathrm{W}$; e et al. ABO blood types and postpartum depression among Chinese women: A prospective cohort study in Tianjin, China. Women Health 2018, 58, 685-698.

66. Matsunaga, E.; Minoda, K. Retinoblastoma and ABO blood groups. Hum. Genet. 1983, $63,87$.

67. Chihara, Y.; Sugano, K.; Kobayashi, A.; Kanai, Y.; Yamamoto, H.; Nakazono, M.; Fujimoto, H.; Kakizoe, T.; Fujimoto, K.; Hirohashi, S.; et al. Loss of blood group A antigen expression in bladder cancer caused by allelic loss and/or methylation of the ABO gene. Lab. Investig. J. Tech. Methods Pathol. 2005, 85, 895-907.

68. Risch, H.A. Pancreatic cancer: Helicobacter pylori colonization, N-nitrosamine exposures, and ABO blood group. Mol. Carcinog. 2012, 51, 109-118.

69. Dabelsteen, E.; Gao, S. ABO blood-group antigens in oral cancer. J. Dent. Res. 2005, 84, 21-28.

70. Sharara, A.I.; Abdul-Baki, H.; ElHajj, I.; Kreidieh, N.; Kfoury Baz, E.M. Association of gastroduodenal disease phenotype with $\mathrm{ABO}$ blood group and Helicobacter pylori virulence-specific serotypes. Dig. Liver Dis. Off. J. Ital. Soc. Gastroenterol. Ital. Assoc. Study Liver 2006, 38, 829-833.

71. Kellesarian, S.V.; Yunker, M.; Malmstrom, H.; Almas, K.; Romanos, G.E.; Javed, F. Male Infertility and Dental Health Status: A Systematic Review. Am. J. Mens Health 2018, 12, 1976-1984.

72. Juul, S.; Karmaus, W.; Olsen, J. Regional differences in waiting time to pregnancy: pregnancy-based surveys from Denmark, France, Germany, Italy and Sweden. Hum. Reprod. 1999, 14, 1250-1254.

73. Rooney, K.L.; Domar, A.D. The relationship between stress and infertility. Dialogues Clin. Neurosci. 2018, 20, 41-47.

74. Andrology: Male Reproductive Health and Dysfunction; Nieschlag, E., Behre, H.M., Nieschlag, S., Eds.; 3rd ed.; Springer-Verlag: Berlin Heidelberg, 2010; ISBN 978-3-54078354-1.

75. Barratt, C.L.R.; Björndahl, L.; De Jonge, C.J.; Lamb, D.J.; Osorio Martini, F.; McLachlan, R.; Oates, R.D.; van der Poel, S.; St John, B.; Sigman, M.; et al. The diagnosis of male infertility: an analysis of the evidence to support the development of 
global WHO guidance-challenges and future research opportunities. Hum. Reprod. Update 2017, 23, 660-680.

76. Klinger, A.; Hain, B.; Yaffe, H.; Schonberger, O. Periodontal status of males attending an in vitro fertilization clinic. J. Clin. Periodontol. 2011, 38, 542-546.

77. Rashidi Maybodi, F.; Amirzade Iranaq, M.H. poor oral health and fertility problems: A narrative mini-review. J. Midwifery Reprod. Health 2017, 5, 849-854.

78. Kaur, G.; Grover, V.; Bhaskar, N.; Kaur, R.K.; Jain, A. Periodontal Infectogenomics. Inflamm. Regen. 2018, 38, 8.

79. Demir, B.; Guven, S.; Guven, E.S.G.; Atamer, Y.; Gul, T. Serum IL-6 level may have role in the pathophysiology of unexplained infertility. Am. J. Reprod. Immunol. N. Y. N 1989 2009, 62, 261-267.

80. Kumar, N.; Singh, A.K. Trends of male factor infertility, an important cause of infertility: A review of literature. J. Hum. Reprod. Sci. 2015, 8, 191-196.

81. Bieniek, K.W.; Riedel, H.H. Bacterial foci in the teeth, oral cavity, and jaw--secondary effects (remote action) of bacterial colonies with respect to bacteriospermia and subfertility in males. Andrologia 1993, 25, 159-162.

82. Al-Subaihi, A.A. Sample size determination. Influencing factors and calculation strategies for survey research. Saudi Med. J. 2003, 24, 323-330.

83. Chen, C.-P.; Peng, Y.-S.; Weng, H.-H.; Fan, J.-Y.; Guo, S.-E.; Yen, H.-Y.; Tseng, Y.-F.; Chen, M.-Y. Development and preliminary testing of a brief screening measure of healthy lifestyle for diabetes patients. Int. J. Nurs. Stud. 2013, 50, 90-99.

84. Pásztor, N.; Kárpáti, K.; Szöllősi, J.; Keresztúri, M.; Kozinszky, Z.; Gorzó, I.; Radnai, M. Association between periodontal status and idiopathic male infertility. J. Oral Sci. 2016, 58, 247-253.

85. Kárpáti, K.; Braunitzer, G.; Toldi, J.; Turzó, K.; Virág, K.; Reiche, W.T.; Rakonczay, Z.; Nagy, K. Caries and ABO secretor status in a Hungarian population of children and adolescents: an exploratory study. Caries Res. 2014, 48, 179-185.

86. Akhter, R.; Hassan, N.M.M.; Martin, E.F.; Muhit, M.; Smithers-sheedy, H.; Badawi, N.; Khandaker, G. Caries experience and oral health-related quality of life (OHRQoL) of children and adolescents with cerebral palsy in a low-resource setting. BMC Oral Health 2019, 19, 15.

87. Vernazza, C.R.; Rolland, S.L.; Chadwick, B.; Pitts, N. Caries experience, the caries burden and associated factors in children in England, Wales and Northern Ireland 2013. Br. Dent. J. 2016, 221, 315-320.

88. Gugnani, N.; Pandit, I.K.; Gupta, M.; Josan, R. Caries infiltration of noncavitated white spot lesions: A novel approach for immediate esthetic improvement. Contemp. Clin. Dent. 2012, 3, S199-S202.

89. Greene, J.C.; Vermillion, J.R. THE SIMPLIFIED ORAL HYGIENE INDEX. J. Am. Dent. Assoc. 1939 1964, 68, 7-13.

90. Greene, J.C. The Oral Hygiene Index--development and uses. J. Periodontol. 1967, 38, Suppl:625-637.

91. Ramfjord, S.P. Indices for Prevalence and Incidence of Periodontal Disease. $J$. Periodontol. 1959, 30, 51-59.

92. Silness, J.; Loe, H. PERIODONTAL DISEASE IN PREGNANCY. II. CORRELATION BETWEEN ORAL HYGIENE AND PERIODONTAL CONDTION. Acta Odontol. Scand. 1964, 22, 121-135.

93. Bobak, C.A.; Barr, P.J.; O’Malley, A.J. Estimation of an inter-rater intra-class correlation coefficient that overcomes common assumption violations in the assessment of health measurement scales. BMC Med. Res. Methodol. 2018, 18, 93. 
94. Gajdács, M.; Paulik, E.; Szabó, A. Knowledge, Attitude and Practice of Community Pharmacists Regarding Antibiotic Use and Infectious Diseases: A Cross-Sectional Survey in Hungary (KAPPhA-HU). Antibiot. Basel Switz. 2020, 9.

95. Bakhtiari, S.; Toosi, P.; Dolati, F.; Bakhshi, M. Evaluation of Salivary Secretor Status of Blood Group Antigens in Patients with Oral Lichen Planus. Med. Princ. Pract. 2016, 25, 266-269.

96. Bukantz, S.C.; Calderon, E.; Lockey, R.F. 510 Assay of $\mathrm{ABO}(\mathrm{H})$ erythrocyte antigen by hemagglutination inhibition of murine monoclonal antiA and antiB antibodies. J. Allergy Clin. Immunol. 1996, 97, 310.

97. Amruthraj, N.J.; Preetam Raj, J.P.; Lebel, A. Capsaicin-capped silver nanoparticles: its kinetics, characterization and biocompatibility assay. Appl. Nanosci. 2015, 5, 403-409.

98. Booth, J.C.; Pay, T.W.; Hedger, R.S.; Barnett, I.T. The use of the haemagglutinationinhibition test for detecting antibodies to type SAT 2 foot-and-mouth disease viruses in cattle sera. J. Hyg. (Lond.) 1975, 74, 115-122.

99. WHO laboratory manual for the examination and processing of human semen; World Health Organization, Ed.; 5th ed.; World Health Organization: Geneva, 2010; ISBN 97892-4-154778-9.

100. Dovere, L. Semen collection, analysis and preparation: a mini review. Curr. Trends Clin. Embriology 2016, 3, 41.

101. Kolmogorov-Smirnov Test. In The Concise Encyclopedia of Statistics; Springer: New York, NY, 2008; pp. 283-287 ISBN 978-0-387-32833-1.

102. Zhang, Y.; Hedo, R.; Rivera, A.; Rull, R.; Richardson, S.; Tu, X.M. Post hoc power analysis: is it an informative and meaningful analysis? Gen. Psychiatry 2019, 32, e100069.

103. Pourhoseingholi, M.A.; Baghestani, A.R.; Vahedi, M. How to control confounding effects by statistical analysis. Gastroenterol. Hepatol. Bed Bench 2012, 5, 79-83.

104. Natto, Z.S.; Aladmawy, M.; Alshaeri, H.K.; Alasqah, M.; Papas, A. Is there a relationship between periodontal conditions and number of medications among the elderly? Ghana Med. J. 2016, 50, 9-15.

105. Mavridis, N.; Achimastos, A. Secretor status and dental caries. J. Dent. Res. 1974, 53, 949.

106. Barros, L.; Witkop, C.J. Oral and genetic study of Chileans 1960. III. Periodontal disease and nutritional factors. Arch. Oral Biol. 1963, 8, 195-206.

107. Holbrook, W.P.; Magnúsdóttir, M.O. Studies on strains of Streptococcus mutans isolated from caries-active and caries-free individuals in Iceland. J. Oral Microbiol. 2012, 4.

108. Agustsdottir, H.; Gudmundsdottir, H.; Eggertsson, H.; Jonsson, S.H.; Gudlaugsson, J.O.; Saemundsson, S.R.; Eliasson, S.T.; Arnadottir, I.B.; Holbrook, W.P. Caries prevalence of permanent teeth: a national survey of children in Iceland using ICDAS. Community Dent. Oral Epidemiol. 2010, 38, 299-309.

109. Eriksson, A.W.; Partanen, K.; Frants, R.R.; Pronk, J.C.; Kostense, P.J. ABH secretion polymorphism in Icelanders, Aland Islanders, Finns, Finnish Lapps, Komi and Greenland Eskimos: a review and new data. Ann. Hum. Biol. 1986, 13, 273-285.

110. Green, G.E.; Wilson, R.M.; Freeman, N.C. Human blood types and dental caries experience. J. Dent. Res. 1966, 45, 1818.

111. Achimastos, A.; Mavridis, N.; Hatjiotis, J. Blood groups and dental caries experience in man. J. Dent. Res. 1974, 53, 1300.

112. Genetics of the Hungarian Population: Ethnic Aspects, Genetic Markers, Ecogenetics and Disease Spectrum; Czeizel, A.E., Benkmann, H.-G., Goedde, H.W., Eds.; Springer-Verlag: Berlin Heidelberg, 1991; ISBN 978-3-540-53580-5. 
113. Matulaitiene, Z.K.; Zemaitiene, M.; Zemgulyte, S.; Milciuviene, S. Changes in dental caries and oral hygiene among 7-8 year-old schoolchildren in different regions of Lithuania 1983-2009. Stomatologija 2012, 14, 53-59.

114. Milciuviene, S.; Bendoraitiene, E.; Andruskeviciene, V.; Narbutaite, J.; Sakalauskiene, J.; Vasiliauskiene, I.; Slabsinskiene, E. Dental caries prevalence among 12-15-year-olds in Lithuania between 1983 and 2005. Med. Kaunas Lith. 2009, 45, 6876.

115. Kolawole, K.A.; Oziegbe, E.O.; Bamise, C.T. Oral hygiene measures and the periodontal status of school children. Int. J. Dent. Hyg. 2011, 9, 143-148.

116. Al-Haddad, K.A.; Ibrahim, Y.T.; Al-Haddad, A.M.; Al-Hebshi, N.N. Assessment of Gingival Health Status among 5- and 12-Year-Old Children in Yemen: A Cross-Sectional Study Available online: https://www.hindawi.com/journals/isrn/2013/352621/ (accessed on Mar 15, 2020).

117. Vani, N.V.; Saleh, S.M.; Tubaigy, F.M.; Idris, A.M. Prevalence of developmental dental anomalies among adult population of Jazan, Saudi Arabia. Saudi J. Dent. Res. 2016, 7, 29-33.

118. Wilson, P.R.; Beynon, A.D. Mineralization differences between human deciduous and permanent enamel measured by quantitative microradiography. Arch. Oral Biol. 1989, 34, 85-88.

119. Ando, M.; van Der Veen, M.H.; Schemehorn, B.R.; Stookey, G.K. Comparative study to quantify demineralized enamel in deciduous and permanent teeth using laser- and light-induced fluorescence techniques. Caries Res. 2001, 35, 464-470.

120. Sabel, N. Enamel of primary teeth--morphological and chemical aspects. Swed. Dent. J. Suppl. 2012, 1-77, 2p preceding i.

121. Cote, S.; Geltman, P.; Nunn, M.; Lituri, K.; Henshaw, M.; Garcia, R.I. Dental caries of refugee children compared with US children. Pediatrics 2004, 114, e733-740.

122. Warren, J.J.; Slayton, R.L.; Yonezu, T.; Kanellis, M.J.; Levy, S.M. Interdental spacing and caries in the primary dentition. Pediatr. Dent. 2003, 25, 109-113.

123. Faragó, I.; Nagy, G.; Márton, S.; Túry, F.; Szabó, E.; Hopcraft, M.; Madléna, M. Dental caries experience in a Hungarian police student population. Caries Res. 2012, 46, 95-101.

124. Madléna, M.; Nagy, G.; Nemes, J.; Keszthelyi, G. [Dietary habits and oral hygiene in school children in the city of Debrecen]. Fogorv. Sz. 1993, 86, 305-313.

125. Szöke, J.; Petersen, P.E. [Oral health of the child population. I. Situation in Hungary based on the epidemiologic study conducted for the WHO Oral Data Bank in 1996]. Fogorv. Sz. 1998, 91, 305-314.

126. Szóke, J.; Petersen, P.E. [Oral health of 18-year-old adolescents in Hungary]. Fogorv. Sz. 2001, 94, 185-190.

127. Honkala, E.; Kannas, L.; Rise, J. Oral health habits of schoolchildren in 11 European countries. Int. Dent. J. 1990, 40, 211-217.

128. Jain, M.; Dogra, V.; Mishra, B.; Thakur, A.; Loomba, P.S.; Bhargava, A. Candiduria in catheterized intensive care unit patients: emerging microbiological trends. Indian $J$. Pathol. Microbiol. 2011, 54, 552-555.

129. Tabak, L.A.; Levine, M.J.; Mandel, I.D.; Ellison, S.A. Role of salivary mucins in the protection of the oral cavity. J. Oral Pathol. 1982, 11, 1-17.

130. Aas, J.A.; Griffen, A.L.; Dardis, S.R.; Lee, A.M.; Olsen, I.; Dewhirst, F.E.; Leys, E.J.; Paster, B.J. Bacteria of Dental Caries in Primary and Permanent Teeth in Children and Young Adults. J. Clin. Microbiol. 2008, 46, 1407-1417. 
131. Williams, R.C.; Gibbons, R.J. Inhibition of streptococcal attachment to receptors on human buccal epithelial cells by antigenically similar salivary glycoproteins. Infect. Immun. 1975, 11, 711-718.

132. Ge, J.; Catt, D.M.; Gregory, R.L. Streptococcus mutans Surface $\alpha$-Enolase Binds Salivary Mucin MG2 and Human Plasminogen. Infect. Immun. 2004, 72, 6748-6752.

133. Frenkel, E.S.; Ribbeck, K. Salivary mucins in host defense and disease prevention. $J$. Oral Microbiol. 2015, 7.

134. Koop, H.M.; Valentijn-Benz, M.; Nieuw Amerongen, A.V.; Roukema, P.A.; de Graaff, J. Involvement of human mucous saliva and salivary mucins in the aggregation of the oral bacteria Streptococcus sanguis, Streptococcus oralis, and Streptococcus rattus. Antonie Van Leeuwenhoek 1990, 57, 245-252.

135. Maddi, A.; Scannapieco, F.A. Oral biofilms, oral and periodontal infections, and systemic disease. Am. J. Dent. 2013, 26, 249-254.

136. Chandki, R.; Banthia, P.; Banthia, R. Biofilms: A microbial home. J. Indian Soc. Periodontol. 2011, 15, 111-114.

137. Davenport, E.R.; Goodrich, J.K.; Bell, J.T.; Spector, T.D.; Ley, R.E.; Clark, A.G. $\mathrm{ABO}$ antigen and secretor statuses are not associated with gut microbiota composition in 1,500 twins. BMC Genomics 2016, 17, 941.

138. Pardoe, G.I.; Uhlenbruck, G. Genetics and immunochemistry of blood group antigens. Med. Lab. Technol. 1971, 28, 1-18.

139. Marcus, D.M. The ABO and Lewis blood-group system. Immunochemistry, genetics and relation to human disease. N. Engl. J. Med. 1969, 280, 994-1006.

140. Nwhator, S.O.; Umeizudike, K.A.; Ayanbadejo, P.O.; Opeodu, O.I.; Olamijulo, J.A.; Sorsa, T. Another reason for impeccable oral hygiene: oral hygiene-sperm count link. $J$. Contemp. Dent. Pract. 2014, 15, 352-358.

141. Amann, R.P. The cycle of the seminiferous epithelium in humans: a need to revisit? J. Androl. 2008, 29, 469-487.

142. Brinig, M.M.; Lepp, P.W.; Ouverney, C.C.; Armitage, G.C.; Relman, D.A. Prevalence of bacteria of division TM7 in human subgingival plaque and their association with disease. Appl. Environ. Microbiol. 2003, 69, 1687-1694.

143. Lang, N.P.; Joss, A.; Orsanic, T.; Gusberti, F.A.; Siegrist, B.E. Bleeding on probing. A predictor for the progression of periodontal disease? J. Clin. Periodontol. 1986, 13, 590-596.

144. Lang, N.P.; Suvan, J.E.; Tonetti, M.S. Risk factor assessment tools for the prevention of periodontitis progression a systematic review. J. Clin. Periodontol. 2015, 42, S59-S70.

145. Radnai, M.; Pál, A.; Novák, T.; Urbán, E.; Eller, J.; Gorzó, I. Benefits of periodontal therapy when preterm birth threatens. J. Dent. Res. 2009, 88, 280-284.

146. Lindhe, J.; Socransky, S.S.; Nyman, S.; Haffajee, A.; Westfelt, E. "Critical probing depths" in periodontal therapy. J. Clin. Periodontol. 1982, 9, 323-336.

147. Clinical Periodontology and Implant Dentistry, 2 Volume Set, 6th Edition | Wiley Available online: https://www.wiley.com/enhu/Clinical+Periodontology+and+Implant+Dentistry\%2C+2+Volume+Set\%2C+6th+Editi on-p-9780470672488 (accessed on Mar 15, 2020).

148. Löe, H.; Anerud, A.; Boysen, H.; Morrison, E. Natural history of periodontal disease in man. Rapid, moderate and no loss of attachment in Sri Lankan laborers 14 to 46 years of age. J. Clin. Periodontol. 1986, 13, 431-445.

149. Mumghamba, E.G.S.; Pitiphat, W.; Matee, M.I.N.; Simon, E.; Merchant, A.T. The usefulness of using Ramfjord teeth in predicting periodontal status of a Tanzanian adult population. J. Clin. Periodontol. 2004, 31, 16-18. 
150. Domes, T.; Lo, K.C.; Grober, E.D.; Mullen, J.B.M.; Mazzulli, T.; Jarvi, K. The incidence and effect of bacteriospermia and elevated seminal leukocytes on semen parameters. Fertil. Steril. 2012, 97, 1050-1055.

151. Chrysanthakopoulos, N.A. Risk factors for the progression of periodontal disease in a Greek adult population. J. Investig. Clin. Dent. 2017, 8, e12199.

152. Bandel, I.; Bungum, M.; Richtoff, J.; Malm, J.; Axelsson, J.; Pedersen, H.S.; Ludwicki, J.K.; Czaja, K.; Hernik, A.; Toft, G.; et al. No association between body mass index and sperm DNA integrity. Hum. Reprod. 2015, 30, 1704-1713.

153. Lingappa, H.A.; Govindashetty, A.M.; Puttaveerachary, A.K.; Manchaiah, S.; Krishnamurthy, A.; Bashir, S.; Doddaiah, N. Evaluation of Effect of Cigarette Smoking on Vital Seminal Parameters which Influence Fertility. J. Clin. Diagn. Res. JCDR 2015, 9, EC13-EC15.

154. Potts, R.J.; Newbury, C.J.; Smith, G.; Notarianni, L.J.; Jefferies, T.M. Sperm chromatin damage associated with male smoking. Mutat. Res. 1999, 423, 103-111.

155. Chambrone, L.; Preshaw, P.M.; Rosa, E.F.; Heasman, P.A.; Romito, G.A.; Pannuti, C.M.; Tu, Y.-K. Effects of smoking cessation on the outcomes of non-surgical periodontal therapy: a systematic review and individual patient data meta-analysis. J. Clin. Periodontol. 2013, 40, 607-615.

156. Prentki Santos, E.; López-Costa, S.; Chenlo, P.; Pugliese, M.N.; Curi, S.; Ariagno, J.; Repetto, H.; Sardi, M.; Palaoro, L.; Mendeluk, G. Impact of spontaneous smoking cessation on sperm quality: case report. Andrologia 2011, 43, 431-435.

157. Cullinan, M.P.; Seymour, G.J. Periodontal disease and systemic illness: will the evidence ever be enough? Periodontol. 2000 2013, 62, 271-286.

158. Noack, B.; Genco, R.J.; Trevisan, M.; Grossi, S.; Zambon, J.J.; De Nardin, E. Periodontal infections contribute to elevated systemic C-reactive protein level. $J$. Periodontol. 2001, 72, 1221-1227.

159. Paraskevas, S.; Huizinga, J.D.; Loos, B.G. A systematic review and meta-analyses on C-reactive protein in relation to periodontitis. J. Clin. Periodontol. 2008, 35, 277-290.

160. Schell, C.; Albrecht, M.; Mayer, C.; Schwarzer, J.U.; Frungieri, M.B.; Mayerhofer, A. Exploring human testicular peritubular cells: identification of secretory products and regulation by tumor necrosis factor-alpha. Endocrinology 2008, 149, 1678-1686.

161. Xia, W.; Wong, E.W.P.; Mruk, D.D.; Cheng, C.Y. TGF-beta3 and TNFalpha perturb blood-testis barrier (BTB) dynamics by accelerating the clathrin-mediated endocytosis of integral membrane proteins: a new concept of BTB regulation during spermatogenesis. Dev. Biol. 2009, 327, 48-61.

162. Zhang, H.; Yin, Y.; Wang, G.; Liu, Z.; Liu, L.; Sun, F. Interleukin-6 disrupts bloodtestis barrier through inhibiting protein degradation or activating phosphorylated ERK in Sertoli cells. Sci. Rep. 2014, 4, 1-7.

163. Eberhard, J.; Grote, K.; Luchtefeld, M.; Heuer, W.; Schuett, H.; Divchev, D.; Scherer, R.; Schmitz-Streit, R.; Langfeldt, D.; Stumpp, N.; et al. Experimental gingivitis induces systemic inflammatory markers in young healthy individuals: a single-subject interventional study. PloS One 2013, 8, e55265.

164. Kinane, D.F.; Zhang, P.; Benakanakere, M.; Singleton, J.; Biesbrock, A.; Nonnenmacher, C.; He, T. Experimental gingivitis, bacteremia and systemic biomarkers: a randomized clinical trial. J. Periodontal Res. 2015, 50, 864-869. 


\section{PUBLICATIONS}




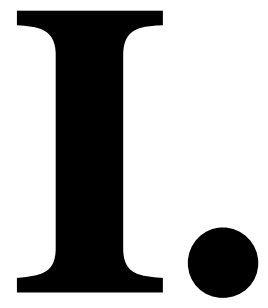


Original

\title{
Association between periodontal status and idiopathic male infertility
}

\author{
Norbert Pásztor ${ }^{1)}$, Krisztina Kárpáti ${ }^{2)}$, János Szöllősi ${ }^{1)}$, Márk Keresztúri ${ }^{3)}$, \\ Zoltan Kozinszky ${ }^{4)}$, István Gorzós), and Márta Radnai')
}
${ }^{1)}$ Department of Obstetrics and Gynecology, Medical Faculty, University of Szeged, Szeged, Hungary
${ }^{2)}$ Department of Prosthodontics, Faculty of Dentistry, University of Szeged, Szeged, Hungary
${ }^{3)}$ Faculty of Dentistry, University of Szeged, Szeged, Hungary
${ }^{4}$ Department of Obstetrics and Gynaecology, Blekinge Hospital, Karlskrona, Sweden
${ }^{5}$ Department of Periodontology, Faculty of Dentistry, University of Szeged, Szeged, Hungary
${ }^{6}$ Department of Prosthodontics, Department of Dentistry, Oral and Maxillofacial Surgery, University of Pécs Medical School, Pécs, Hungary

(Received October 27, 2015; Accepted February 3, 2016)

\begin{abstract}
About 30\% of male infertility cases are idiopathic. Previous studies reported a positive correlation between deep periodontal pockets and sperm sub-motility, which suggests that periodontitis might have a role in idiopathic semen abnormality pathospermia. We evaluated correlations between periodontal infection parameters and the results of sperm analysis of men with idiopathic infertility. In this observational study, semen quality and periodontal status were analyzed for 95 otherwise healthy men attending an andrology unit for sperm analysis. Half the men in the sperm pathology and normozoospermia groups $\mathbf{5 0 . 8 \%}$ and $\mathbf{5 0 \%}$, respectively) had poor periodontal status. Among the 95 participants, $38 \%$ had oligozoospermia, $28 \%$ had asthenozoospermia, $16 \%$ had cryptozoospermia, and $15 \%$ were classified as normozoospermic. Sperm pathology category was not associated with frequency of deep periodontal pockets or calculus. Bleeding on probing was significantly lower among men with asthenozoospermia than among those with normozoospermia. Poor periodontal status was not associated with any sperm pathology category or parameter. In contrast
\end{abstract}

Correspondence to Dr. Norbert Pásztor, 6725 Szeged, Semmelweis u. 1, Hungary

Fax:+36-62-545-711 E-mail: hirt78@gmail.com

doi.org/10.2334/josnusd.15-0586

DN/JST.JSTAGE/josnusd/15-0586 with previous findings, the present results indicate that pathospermia and poor semen quality are not associated with periodontal infection in men with idiopathic infertility. (J Oral Sci 58, 247-253, 2016)

Keywords: idiopathic male infertility; pathospermia; periodontal status; periodontitis.

\section{Introduction}

Gingivitis and chronic periodontitis are common chronic diseases in adults worldwide (1-3). Poor dental health can adversely affect a number of systemic conditions and diseases, such as cardiovascular diseases (4), diabetes (5), respiratory diseases (6), and inflammatory bowel diseases (7), and can even lead to preterm delivery $(8,9)$ and systemic disease (10-12). However, the associations between periodontal disease and sperm abnormalities have not been adequately investigated.

The estimated prevalence of infertility among couples of reproductive age is $15 \%$ (13), and almost half of such cases are attributable to disturbances in male fertility (14). Although the causes of male infertility have been extensively investigated, $25 \%$ of male infertility cases are idiopathic (14). Periodontitis might have a role in subfertility (15). A direct causal relationship was suspected between bacterial colonies in dental foci and therapy-resistant bacteriospermia (15). Furthermore, other studies reported a positive correlation between 
deep periodontal pockets and sperm submotility (16). However, no previous study focused on men with idiopathic infertility. Hence, we investigated the relationship between periodontal status and spermiogram parameters in men with idiopathic infertility.

\section{Materials and Methods}

Male patients seeking infertility evaluation were recruited at the Andrology Outpatient Clinic in the Department of Obstetrics and Gynaecology of the University of Szeged, Hungary, between 1 October 2010 and 30 July 2013. Sociodemographic data (age, place of residence, education level, and profession) and information on lifestyle factors (smoking, alcohol consumption, and drug abuse) were collected via a self-reported questionnaire, followed by andrological and periodontal examinations.

\section{Semen collection and analysis}

Semen was analyzed and classified according to the World Health Organization (WHO) criteria (17). After 3-5 days of abstinence, semen samples were obtained by masturbation and ejaculation into glass containers in a private room close to the laboratory. The samples were handled at room temperature $\left(22-25^{\circ} \mathrm{C}\right)$, and semen analysis began within $1 \mathrm{~h}$ after ejaculation. Sperm concentration, total sperm count, total sperm motility, and progressive and nonprogressive motility were assessed with phase-contrast optics at $\times 200$ magnification in a Makler counting chamber (FertiCAD Kft., Budapest, Hungary), as described in the WHO laboratory manual for the examination of human semen (17). Sperm morphology was determined at $\times 1,000$ magnification with oil immersion after Diff-Quik staining (Diff-Quik Staining Set, Medion Diagnostics AG, Düdingen, Switzerland). Progressive motility was specified as the proportion of actively moving spermatozoa. Nonprogressive motility was defined as the percentage of moving spermatozoa with no evidence of progression. Total motility was the sum of progressive and nonprogressive motility. Normozoospermia was classified as a normal ejaculation, as defined by WHO reference values, namely, a sperm cell concentration of $15 \times 10^{6} / \mathrm{mL}$ or greater, a total sperm count of $39 \times 10^{6}$ per ejaculate or greater, total motility of at least $40 \%$, and progressive motility of $32 \%$ or greater. Cryptozoospermia was diagnosed when spermatozoa were absent from a fresh preparation but were observed in a centrifuged pellet. Teratozoospermia was diagnosed when the proportion of sperm cells with normal morphology was less than $4 \%$. In cases of oligozoospermia (sperm concentration $<15$ $\times 10^{6} / \mathrm{mL}$ ) and asthenozoospermia (progressive motility
$<32 \%$ ), a blood sample was collected for measurement of hormone levels, and an ultrasound examination of the testes was performed. When sperm concentration was less than $1 \times 10^{6} / \mathrm{mL}$, screening for karyotyping and azoospermia factor microdeletion of the $\mathrm{Y}$ chromosome (AZFa /sY84,86/; AZFb /sY127,134/; AZFc/sY254,255/ regions) was also performed.

Only men with idiopathic infertility were enrolled in the study. Men were excluded from the study if they had a varicocele or testicular microlithiasis (confirmed by ultrasound examination), hypogonadism (verified by hormonal measurements), a genetic disorder (determined by chromosome analysis or molecular genetic investigations), or symptoms of genital infection. Patients with azoospermia (no spermatozoa in ejaculate) were also excluded because of the possibility of seminal duct obstruction or serious testicular abnormality.

\section{Periodontal examination}

Where it was impossible to measure probing depth (PD), wisdom teeth and radices were excluded from periodontal charting. The amount of plaque was recorded on a 0 to 3 scale on the "Ramfjord teeth" (\#16, 21, 24, 36, 41 , and 44) (18) at four surfaces per tooth, according to the criteria developed by Silness and Löe (19). If a Ramfjord tooth was missing, the adjacent molar, premolar, or central incisor was examined. PD was measured at six sites on each tooth (mesiobuccal, midbuccal, distobuccal, mesiolingual, midlingual, and distolingual) with a millimeter-scale Michigan periodontal probe (Hu-Friedy, Chicago, IL, USA). PD values were recorded in millimeters and rounded down to the nearest whole millimeter. Sulcus bleeding on probing (BOP) was classified as positive if bleeding occurred within $15 \mathrm{~s}$ after probing at any tooth site. Dental calculus was recorded dichotomously as present or absent. The number of missing teeth was also recorded. Poor periodontal status was defined as a probing depth of $\geq 4 \mathrm{~mm}$ for at least at one tooth site and BOP at $50 \%$ or more of teeth (8). Periodontal examination was repeated for 10 patients after an interval of 30 $\mathrm{min}$, and the intraclass correlation coefficient was 0.90 .

The dental characteristics of the oligozoospermia, asthenozoospermia, cryptozoospermia, and sperm pathology (men with any sperm abnormality) groups were compared with those of normozoospermic men (control group). Patients with oligo-asthenozoospermia were included in both the oligozoospermic and asthenozoospermic groups. The dentist was blinded to the andrological status of patients. All dental examinations were performed by one of two authors (M.R. and K.K.), both of whom are experienced in periodontal charting. 
Table 1 Characteristics of men with idiopathic male infertility treated at the Department of Obstetrics and Gynecology, University of Szeged (1 October 2010 through 30 July 2013)

\begin{tabular}{lcc}
\hline Age & $n=95(100 \%)$ & \\
Mean & & $35.1 \pm 5.7$ years \\
Minimum & 23.9 years \\
Maximum & 52.1 years \\
Place of residence & $n=95(100 \%)$ & \\
$\quad$ City & & $74(77.9 \%)$ \\
Village & $21(22.1 \%)$ \\
Educational level & \\
Primary school & & $1(1.1 \%)$ \\
Technical school & $28(29.5 \%)$ \\
Grammar school General secondary school & & $33(34.7 \%)$ \\
Higher education & $33(34.7 \%)$ \\
Occupation & & \\
Unemployed & & $2(2.1 \%)$ \\
Manual worker & & $41(43.1 \%)$ \\
Other & $23(24.2 \%)$ \\
Intellectual White-collar worker & $29(30.7 \%)$ \\
Smoking & $n=95(100 \%)$ & \\
No & & $69(72.6 \%)$ \\
Yes & & $26(27.4 \%)$ \\
5 cigarettes/day & $10(10.5 \%)$ \\
10 cigarettes/day & $10(10.5 \%)$ \\
20 cigarettes/day & $6(6.3 \%)$ \\
Past smoking & $44(46.3 \%)$ \\
Quit $>5$ years before & $13(13.7 \%)$ \\
BMI & & \\
$>30$ & & $16(16.8 \%)$ \\
$\leq 30$ & $79(83.2 \%)$ \\
\hline Date &
\end{tabular}

Data are presented as number (\%), unless otherwise indicated.

The study protocol was approved by the Regional and Institutional Human Medical Biological Research Ethics Committee of the University of Szeged, Hungary, in 2010 (Protocol No. 97/2010). Informed consent was obtained from all study participants.

\section{Statistical analyses}

Statistical analyses were performed with the SPSS for Windows program, Version 15 (SPSS Inc., Chicago, IL, USA). The Kolmogorov-Smirnov test confirmed that data for our study samples were not normally distributed. Continuous variables were expressed as mean \pm SD. The Mann-Whitney $U$ test was used for comparison of continuous variables, depending on case-control status (pathospermia vs. normal cases; poor periodontal status vs. healthy periodontium). Univariate comparisons of categorical variables were done with the $\chi^{2}$ test. The correlation between the sperm parameters and total number of teeth was determined by using Spearman rank correlations. Statistical significance was defined as a two-sided $P$ value of 0.05 or lower. Repeatability of the periodontal examination was assessed using intraclass correlation coefficients. Odds ratios for continuous variables were evaluated by univariate logistic regression and were adjusted for confounding factors (age, smoking status, and body mass index) in multiple logistic regression analysis.

\section{Results}

During the study period, 95 men were consecutively recruited into the study. Their sociodemographic characteristics are summarized in Table 1 . The average age of the participants was 35.1 years (range: 23-51 years). Overall, 26 men (27.4\%) smoked and $16.8 \%$ were obese, and $36(37.9 \%)$ were oligozoospermic and 27 (28.4\%) were asthenozoospermic (15 patients had both disorders). Cryptozoospermia was diagnosed in $15(15.8 \%)$ of the men, and 32 (33.7\%) men were normozoospermic. Some type of sperm abnormality was noted in $63(66.3 \%)$ men. Teratozoospermia was diagnosed in five men (5.2\%).

Periodontal examination results were analyzed in relation to spermiogram group (Table 2). The mean plaque index was 0.69 in the sperm pathology group and 0.63 in the control group. Among men with any type of sperm abnormality, average PD was $2.19 \mathrm{~mm}$ and BOP was observed at $55.5 \%$ of teeth; in normozoospermic men the respective values were $1.99 \mathrm{~mm}$ and $53.9 \%$. A PD of $\geq 4$ $\mathrm{mm}$ was more frequent in men with a sperm abnormality than in the control group, although the difference was not significant (44 [69.8\%] vs. 18 [56.3\%]). Sixty-two 
Table 2 Dental characteristics of men with idiopathic male infertility, according to sperm pathology, treated at the Department of Obstetrics and Gynecology, University of Szeged (1 October 2010 through 30 July 2013)

\begin{tabular}{|c|c|c|c|c|c|c|c|c|c|c|c|c|c|c|c|c|c|}
\hline & $\begin{array}{c}\text { Crypto- } \\
\text { zoospermia } \\
(n=15)\end{array}$ & $P$ value & $\begin{array}{c}\mathrm{OR} \\
(95 \% \mathrm{CI})\end{array}$ & $\begin{array}{c}\mathrm{AOR} \\
(95 \% \mathrm{Cl})\end{array}$ & $\begin{array}{c}\text { Astheno- } \\
\text { zoospermia } \\
(n=27)\end{array}$ & $P$ value & $\begin{array}{c}\mathrm{OR} \\
(95 \% \mathrm{CI})\end{array}$ & $\begin{array}{c}\mathrm{AOR} \\
(95 \% \mathrm{Cl})\end{array}$ & $\begin{array}{c}\text { Oligozoo- } \\
\text { spermia } \\
(n=36) \\
\end{array}$ & value & $\begin{array}{c}\mathrm{OR} \\
(95 \% \mathrm{Cl})\end{array}$ & $\begin{array}{c}\mathrm{AOR} \\
(95 \% \mathrm{CI})\end{array}$ & $\begin{array}{c}\text { Any sperm- } \\
\text { pathology } \\
(n=63)\end{array}$ & $P$ value & $\begin{array}{c}\mathrm{OR} \\
(95 \% \mathrm{Cl})\end{array}$ & $\begin{array}{l}\mathrm{AOR} \\
95 \% \mathrm{CI})\end{array}$ & $\begin{array}{c}\text { Normo- } \\
\text { zoospermia } \\
(n=32)\end{array}$ \\
\hline Plaqu & $0.66 \pm 0.40$ & 0.46 & $\begin{array}{c}1.32 \\
(0.39-4.39)\end{array}$ & $\begin{array}{c}2.39 \\
(0.55-10.45)\end{array}$ & $0.59 \pm 0.42$ & 0.79 & $\begin{array}{c}0.85 \\
(0.30-2.46)\end{array}$ & $(0.31-3.06)$ & $0.73 \pm 0.43$ & 13 & $\begin{array}{l}1.70 \\
.62-4.66)\end{array}$ & $\begin{array}{c}2.03 \\
(0.68-6.12)\end{array}$ & $0.69 \pm 0.42$ & .23 & $\begin{array}{c}1.43 \\
(0.56-3.66)\end{array}$ & $\begin{array}{c}1.94 \\
(0.68-5.48)\end{array}$ & $0.59 \pm 0.55$ \\
\hline $\mathrm{D}(\mathrm{n}$ & +06 & 0.72 & $\begin{array}{c}1.03 \\
(0.37-2.82)\end{array}$ & $\begin{array}{c}1.04 \\
(0.32-3.38)\end{array}$ & 73 & 0 & $\begin{array}{c}0.58 \\
(0.25-1.32)\end{array}$ & $\begin{array}{c}0.55 \\
(0.23-1.31)\end{array}$ & .58 & 0.07 & $\begin{array}{c}0.44 \\
(0.18-1.04)\end{array}$ & $\begin{array}{c}0.39 \\
(0.1-0.98)\end{array}$ & 68 & 17 & $\begin{array}{c}0.64 \\
(0.33-1.22)\end{array}$ & $\begin{array}{c}0.61 \\
(0.31-1.20)\end{array}$ & .61 \\
\hline & $10(66.7 \%)$ & 0.50 & $\begin{array}{c}1.56 \\
(0.43-5.60)\end{array}$ & $\begin{array}{c}2.28 \\
(0.46-11.23)\end{array}$ & $21(77.8 \%)$ & 0.08 & $\begin{array}{c}2.72 \\
(0.87-8.55)\end{array}$ & $\begin{array}{c}3.07 \\
(0.87-10.91)\end{array}$ & $(69.4 \%)$ & 0.26 & $\begin{array}{c}1.77 \\
(0.65-4.78)\end{array}$ & $\begin{array}{c}1.82 \\
(0.64-5.19)\end{array}$ & $4(69.8 \%)$ & 0.19 & $\begin{array}{c}1.80 \\
(0.75-4.35)\end{array}$ & $\begin{array}{c}1.89 \\
(0.74-4.83)\end{array}$ & $18(56.3 \%)$ \\
\hline $\begin{array}{l}\text { Average number } \\
\text { of } \mathrm{PD} \geq 4 \mathrm{~mm}\end{array}$ & $15.87 \pm 22.41$ & 0.50 & $\begin{array}{c}1.01 \\
(0.98-1.04)\end{array}$ & $\begin{array}{c}1.01 \\
(0.97-1.04)\end{array}$ & 57 & 0.98 & $\begin{array}{c}0.99 \\
(0.97-1.02)\end{array}$ & $\begin{array}{c}0.99 \\
(0.96-1.02)\end{array}$ & 41 & 0.54 & $\begin{array}{c}0.98 \\
(0.95-1.01)\end{array}$ & $\begin{array}{c}0.97 \\
(0.94-1.01)\end{array}$ & 25 & 0.66 & $\begin{array}{c}0.99 \\
(0.97-1.01)\end{array}$ & $\begin{array}{c}0.99 \\
(0.97-1.01)\end{array}$ & 1 \\
\hline & 73,301 & 0.24 & $\begin{array}{c}0.39 \\
(0.08-1.85)\end{array}$ & $\begin{array}{c}0.49 \\
(0.08-2.98)\end{array}$ & $(741 \%)$ & 0.32 & $\begin{array}{c}0.41 \\
(0.10-1.58)\end{array}$ & $\begin{array}{c}0.49 \\
(0.12-2.04)\end{array}$ & $7.8 \%)$ & 0.35 & $\begin{array}{c}0.50 \\
(0.14-1.85)\end{array}$ & $\begin{array}{c}0.61 \\
(0.16-2.36)\end{array}$ & $49(77.8 \%)$ & 0.41 & $\begin{array}{c}0.50 \\
(0.15-1.67)\end{array}$ & $\begin{array}{c}0.61 \\
(0.17-2.13)\end{array}$ & $28(87.5 \%)$ \\
\hline Missing teeth & $3.40 \pm 3.16$ & 0.86 & $\begin{array}{c}1.00 \\
(0.82-1.23)\end{array}$ & $\begin{array}{c}0.90 \\
(0.67-1.22)\end{array}$ & $3.67 \pm 3.04$ & 0.72 & $\begin{array}{c}1.03 \\
(0.87-1.23)\end{array}$ & $\begin{array}{c}0.97 \\
(0.80-1.19)\end{array}$ & $78 \pm 3.44$ & 0.76 & $\begin{array}{c}1.04 \\
(0.89-1.21)\end{array}$ & $\begin{array}{c}1.01 \\
(0.84-1.21)\end{array}$ & $3.48 \pm 3.15$ & 0.95 & $\begin{array}{c}1.01 \\
(0.88-1.16)\end{array}$ & $\begin{array}{c}0.97 \\
(0.81-1.15)\end{array}$ & $3.38 \pm 2.95$ \\
\hline $\begin{array}{l}\text { Frequency of } \\
\text { BOP/teeth (\%) }\end{array}$ & $17.33 \pm 7.95$ & 0.21 & $\begin{array}{c}1.05 \\
(0.97-1.14)\end{array}$ & $\begin{array}{c}1.04 \\
(0.94-1.14)\end{array}$ & 13 & 0.046 & $\begin{array}{c}0.94 \\
(0.88-1.01)\end{array}$ & $\begin{array}{c}0.93 \\
(0.87-1.00)\end{array}$ & . & 0.14 & $\begin{array}{c}0.96 \\
(0.90-1.02)\end{array}$ & $\begin{array}{c}0.94 \\
(0.88-1.01)\end{array}$ & \pm 8.07 & 0.44 & $\begin{array}{c}0.98 \\
(0.93-1.04)\end{array}$ & $\begin{array}{c}0.97 \\
(0.91-1.03)\end{array}$ & .13 \\
\hline $\begin{array}{l}\text { Frequency of } \\
\text { BOP }(\%)\end{array}$ & $.27 \pm 30.89$ & 0.46 & $\begin{array}{c}1.01 \\
(0.99-1.03)\end{array}$ & $\begin{array}{c}1.01 \\
(0.99-1.03)\end{array}$ & $52.04 \pm 29.39$ & 0.57 & $\begin{array}{c}0.99 \\
(0.98-1.01)\end{array}$ & $\begin{array}{c}1.00 \\
(0.98-1.01)\end{array}$ & $48.00 \pm 30.43$ & 0.29 & $\begin{array}{c}0.99 \\
(0.98-1.01)\end{array}$ & $\begin{array}{c}0.99 \\
(0.98-1.01)\end{array}$ & $53.90 \pm 30.40$ & 0.74 & $\begin{array}{c}1.00 \\
(0.98-1.01)\end{array}$ & $\begin{array}{c}1.00 \\
(0.98-1.01)\end{array}$ & 55.47 \\
\hline $\begin{array}{l}\text { Frequency of BOP } \\
\geq 50 \%(n(\%))\end{array}$ & $(66.7 \%)$ & 1.00 & $\begin{array}{c}1.20 \\
(0.33-4.36)\end{array}$ & $\begin{array}{c}1.19 \\
(0.26-5.49)\end{array}$ & $14(51$ & 0 & $\begin{array}{c}0.65 \\
(0.23-1.83)\end{array}$ & $\begin{array}{c}0.58 \\
(0.19-1.77)\end{array}$ & $7(47.2 \%)$ & 02 & $\begin{array}{c}0.54 \\
(0.20-1.42)\end{array}$ & $\begin{array}{c}0.48 \\
(0.17-1.36)\end{array}$ & $(55.6 \%)$ & 0.66 & $\begin{array}{c}0.75 \\
(0.3-1.79)\end{array}$ & $\begin{array}{c}0.70 \\
(0.28-1.76)\end{array}$ & $(62.5 \%)$ \\
\hline $\begin{array}{l}\text { Frequency of } \\
\text { BOP } \geq 50 \%+\text { PD } \\
\geq 4 \mathrm{~mm}(n(\%))\end{array}$ & $7(46.7 \%)$ & 0.55 & $\begin{array}{c}1.13 \\
(0.33-3.86)\end{array}$ & $\begin{array}{c}1.09 \\
(0.26-4.62)\end{array}$ & $11(40.7 \%)$ & 1.00 & $\begin{array}{c}0.88 \\
(0.31-2.49)\end{array}$ & $\begin{array}{c}0.74 \\
(0.24-2.28)\end{array}$ & $14(38.9 \%)$ & 0.81 & $\begin{array}{c}0.82 \\
(0.31-2.15)\end{array}$ & $\begin{array}{c}0.62 \\
(0.22-1.78)\end{array}$ & $26(41.3 \%)$ & 10.83 & $\begin{array}{c}0.90 \\
(0.38-2.14)\end{array}$ & $\begin{array}{c}0.81 \\
(0.33-2.00)\end{array}$ & $14(43.8 \%)$ \\
\hline
\end{tabular}

Data from all sperm pathology groups were compared with those from the normozoospermia group (the controls). $P$ values were calculated with the Mann-Whitney $U$ test, for continuous variables (expressed as mean $\pm \mathrm{SD}$ ), and differences between categorical variables, expressed as number $(n)$ and rate $(\%)$, were assessed by the $\chi^{2}$ test. Odds ratios for continuous variables were estimated by univariate logistic regression, and adjusted odds ratios were calculated by multiple logistic regression adjusted for age, smoking status, and body mass index. Statistical significance was defined as a two-sided $P$ value of 0.05 or lower.

logistic regression adjusted for age, smoking status, and body mass index. Statistical significance was defined as
(A)OR: (adjusted) odds ratio; $95 \%$ CI: 95\% confidence interval; PD: probing depth; BOP: bleeding on probing.

men had a probing depth $\geq 4 \mathrm{~mm}$ and 15 had a probing depth $\geq 6 \mathrm{~mm}$. Thus, two-thirds of participants had deep pockets and almost one-sixth had very deep pockets. In addition, the frequency of poor periodontal status, defined as concomitant bleeding on probing at $\geq 50 \%$ of teeth and presence of at least one tooth with a PD $\geq 4$ $\mathrm{mm}$ ( $\mathrm{POB} \geq 50 \%+\mathrm{PD} \geq 4 \mathrm{~mm}$ in Table 2 ) was similar in the sperm pathology group and normozoospermia groups (50.8\% and 50\%, respectively). Almost all periodontal characteristics studied did not significantly differ between the controls and any spermiogram group (i.e., men with diagnoses of crypto-, astheno-, or oligozoospermia). Surprisingly, BOP per tooth was significantly lower among men with asthenozoospermia, as compared with the other groups. In addition, teratozoospermia was not significantly associated with adverse periodontal status (data not shown in tables). Poor periodontal status was not significantly associated with any sperm abnormality or sperm parameter (Table 3).

\section{Discussion}

We found no correlation between poor periodontal status and any form of idiopathic pathozoospermia in the present study. Poor periodontal status had no significant effect on semen quality. Two previous studies reported evidence of a possible connection between periodontal characteristics and sperm pathology $(16,20)$. Klinger et al. (16) investigated 75 men attending an in vitro fertilization clinic. Deep periodontal pockets and clinical attachment loss were significantly correlated with sperm submotility. However, there was no such correlation with oligozoospermia or normozoospermia. A similar study, by Nwhator et al. (20), investigated 76 infertile men and found a significant association between deeper periodontal pockets and suboptimal sperm count in men aged 33-38 years, and a correlation between poor oral hygiene and low sperm concentration. However, there was no correlation between oral health and sperm motility. It is important to note that neither study screened potential participants on the basis of cause of infertility $(16,20)$. In addition, spermiogram results were categorized by using earlier reference values for human semen analysis, which were subsequently revised in 2010 (17). Thus, it is difficult to draw conclusions from these conflicting results on associations of chronic gingivitis/periodontitis with male infertility.

Because the duration of spermatogenesis (i.e., from spermatogonium to spermatozoa production) is 74 days in humans (21), we did not assess clinical attachment loss (CAL) in our study. CAL mainly reflects previous periodontal processes and may have a noninfectious cause (e.g., unsatisfactory tooth brushing technique). In addition, not all gingivitis sites develop CAL (22). Our statistical analyses included BOP and PD as the main periodontal parameters. The selection of these variables was based on the design of previous studies. BOP is a known marker of periodontal inflammation (23-25). A PD $\geq 4 \mathrm{~mm}$ is considered "critical probing depth" (26), while lesser PD values are regarded as normal (27). Moreover, BOP and PD are significant factors in 
Table 3 Periodontal status and sperm parameters of men with idiopathic male infertility treated at the Department of Obstetrics and Gynecology, University of Szeged (1 October 2010 through 30 July 2013)

\begin{tabular}{|c|c|c|c|c|c|c|}
\hline & \multicolumn{2}{|c|}{$\begin{array}{l}\text { Poor periodontal status } \\
\qquad(n=48)\end{array}$} & \multicolumn{2}{|c|}{$\begin{array}{l}\text { Healthy periodontium } \\
\qquad(n=47)\end{array}$} & \multirow[t]{2}{*}{$P$ value } & \multirow{2}{*}{$\begin{array}{c}\text { OR } \\
(95 \% \mathrm{CI})\end{array}$} \\
\hline & $n$ & $\%$ & $n$ & $\%$ & & \\
\hline Cryptozoospermia & 9/27 & 33.3 & $6 / 20$ & 30.0 & 1.00 & $\begin{array}{c}1.17 \\
(0.33-4.06)\end{array}$ \\
\hline Asthenozoospermia & $11 / 29$ & 37.9 & $16 / 30$ & 53.3 & 0.299 & $\begin{array}{c}0.53 \\
(0.19-1.51)\end{array}$ \\
\hline Oligozoospermia & $15 / 33$ & 45.5 & $21 / 35$ & 60.0 & 0.33 & $\begin{array}{c}0.56 \\
(0.21-1.46)\end{array}$ \\
\hline Any sperm pathology & $30 / 48$ & 62.5 & $33 / 47$ & 70.2 & 0.516 & $\begin{array}{c}0.707 \\
(0.30-1.66)\end{array}$ \\
\hline Normal morphology $(\%)($ mean \pm SD $)$ & \multicolumn{2}{|c|}{$50.06 \pm 19.42$} & \multicolumn{2}{|c|}{$49.71 \pm 13.13$} & 0.599 & \\
\hline Motility $(\%)($ mean \pm SD) & \multicolumn{2}{|c|}{$51.56 \pm 22.90$} & \multicolumn{2}{|c|}{$50.33 \pm 18.40$} & 0.484 & \\
\hline Progressive motility $(\%)($ mean \pm SD $)$ & \multicolumn{2}{|c|}{$47.41 \pm 23.17$} & \multicolumn{2}{|c|}{$46.23 \pm 18.94$} & 0.570 & \\
\hline Nonprogressive motility (\%) (mean \pm SD) & \multicolumn{2}{|c|}{$4.95 \pm 4.96$} & \multicolumn{2}{|c|}{$3.82 \pm 3.34$} & 0.133 & \\
\hline Sperm concentration & \multicolumn{2}{|c|}{$48.36 \pm 48.59$} & \multicolumn{2}{|c|}{$44.612 \pm 47.02$} & 0.899 & \\
\hline $\begin{array}{l}\text { Total sperm number (concentration } \times \text { semen } \\
\text { volume) (millions) }\end{array}$ & \multicolumn{2}{|c|}{$175.70 \pm 190.82$} & \multicolumn{2}{|c|}{$202.97 \pm 231.52$} & 0.470 & \\
\hline
\end{tabular}

$P$ values were calculated with the Mann-Whitney $U$ test, for continuous variables (expressed as mean $\pm \mathrm{SD}$ ), and differences between categorical variables, expressed as number $(n)$ and rate (\%), were assessed by the $\chi^{2}$ test. Statistical significance was defined as a two-sided $P$ value of 0.05 or lower. 95\% CI: $95 \%$ confidence interval.

assessing the risk of periodontitis recurrence and activity (24). In this study, we elected to record plaque amount on the Ramfjord teeth only, as Löe and colleagues reported that plaque is not the only factor associated with progression of chronic periodontitis (28). In their study, most patients $(81 \%)$ exhibited only moderate progression, despite poor plaque control and gingival inflammation in all participants. Moreover, the present partial-mouth examination reduced examination time, which increased patient convenience and reduced examiner fatigue (29). Data for other variable were collected under full-mouth conditions.

Smoking is one of the most common lifestyle factors that adversely affects periodontal and andrological characteristics. It is a main risk factor for periodontal disease (30) and may have a negative impact on fertility. Tobacco exposure has a detrimental effect on sperm production and motility $(31,32)$ and induces sperm DNA damage (33). In our study sample, $27.4 \%$ of patients were smokers, but there was no significant difference in the proportion of smokers between study groups. Previous studies found that smoking cessation improves periodontal health (34) and has beneficial effects on sperm characteristics (35); thus, patients should be strongly advised to quit smoking.

A number of pathological mechanisms by which periodontal inflammation affects semen quality have been proposed. A previous study found a correlation between antibiotic-resistant bacteriospermia and presence of focal dental bacterial colonies resulting from bacteriemia in the oral cavity (15). Bacteriospermia was eliminated by dental treatment, and post-treatment sperm parameters were better than those in a control group. In contrast, another study found no association between presence of bacteria in semen and sperm parameters (36). Hence, bacteriospermia was not investigated in our research.

Pathogens can cause a remote pathogenic effect by direct action via bacteriemia and by inducing production of several circulating cytokines (37). Increased levels of circulating cytokines, caused by periodontal disease, can trigger C-reactive protein production in the liver $(38,39)$. Similar inflammatory molecules are important in regulating the blood-testis barrier, which affects the function of Sertoli cells. Tumor necrosis factor-alpha, transforming growth factor- $\beta 3$ (40), and interleukin-1 can disturb blood-testis barrier dynamics (41). Interleukin-6 alters blood-testis barrier function by inhibiting protein degradation (42). It should be noted however that because systemic inflammatory markers are not specific to periodontal disease and reflect inflammation from all sources, it is difficult to determine the specific effects of periodontitis. Eberhard et al. (43) found a systemic increase in inflammatory markers, while a recent study by Kinane et al. (44) did not show a similar correlation between short-term experimentally induced gingivitis, bacteriemia, and systemic cytokine levels. In any case, our results indicate that poor periodontal status has no remote effect on sperm production or sperm parameters, since poor oral hygiene did not appear to be linked to adverse sperm parameters in idiopathic infertility. The differences between past $(16,20)$ and present findings 
might be attributable to the stricter diagnostic criteria used for periodontal conditions and pathospermia in our study.

Because some evidence supports a link between inflammatory molecular mechanisms and the pathological profile of spermiograms, it was logical to examine the potential association between periodontal status in infertile men and the results of sperm analysis. In conclusion, although there is a connection between male infertility and other oral pathologies, poor periodontal status was not associated with infertility among men without genital infections or other apparent causes of infertility.

\section{Acknowledgments}

The authors would like to express their gratitude to Dr. Krisztina Boda, for her invaluable advice concerning the statistical evaluation of the data, and to nurses Zsuzsanna Szél, Krisztina Bella, Mária Kiss Juhászné, Éva Kiss, and Lenke Varnyú, who assisted with patient management and administration.

\section{Conflicts of interest and source of funding statement}

The authors declare that there was no institutional, private, or corporate financial support for the present study. No external funding, apart from the support of the authors' institution, was available for this study.

\section{References}

1. Reich E (2001) Trends in caries and periodontal health epidemiology in Europe. Int Dent J 51, 392-398.

2. Albandar JM, Rams TE (2002) Global epidemiology of periodontal diseases: an overview. Periodontol 2000 29, 7-10.

3. Eke PI, Dye BA, Wei L, Thornton-Evans GO, Genco RJ (2012) Prevalence of periodontitis in adults in the United States: 2009 and 2010. J Dent Res 91, 914-920.

4. Kebschull M, Demmer RT, Papapanou PN (2010) "Gum bug, leave my heart alone!"--epidemiologic and mechanistic evidence linking periodontal infections and atherosclerosis. J Dent Res 89, 879-902.

5. Saremi A, Nelson RG, Tulloch-Reid M, Hanson RL, Sievers ML, Taylor GW et al. (2005) Periodontal disease and mortality in type 2 diabetes. Diabetes Care 28, 27-32.

6. Azarpazhooh A, Leake JL (2006) Systematic review of the association between respiratory diseases and oral health. J Periodontol 77, 1465-1482.

7. Vavricka SR, Manser CN, Hediger S, Vögelin M, Scharl M, Biedermann L et al. (2013) Periodontitis and gingivitis in inflammatory bowel disease: a case-control study. Inflamm Bowel Dis 19, 2768-2777.

8. Radnai M, Gorzó I, Urbán E, Eller J, Novák T, Pál A (2006) Possible association between mother's periodontal status and preterm delivery. J Clin Periodontol 33, 791-796.

9. Chambrone L, Guglielmetti MR, Pannuti CM, Chambrone LA (2011) Evidence grade associating periodontitis to preterm birth andor low birth weight: I. A systematic review of prospective cohort studies. J Clin Periodontol 38, 795-808.

10. Seymour GJ, Ford PJ, Cullinan MP, Leishman S, Yamazaki K (2007) Relationship between periodontal infections and systemic disease. Clin Microbiol Infect 13, Suppl 4, 3-10.

11. Otomo-Corgel J, Pucher JJ, Rethman MP, Reynolds MA (2012) State of the science: chronic periodontitis and systemic health. J Evid Based Dent Pract 12, 20-28.

12. Tonetti MS, Van Dyke TE (2013) Periodontitis and atherosclerotic cardiovascular disease: consensus report of the Joint EFP/AAP Workshop on Periodontitis and Systemic Diseases. J Periodontol 84, S24-29.

13. Juul S, Karmaus W, Olsen J (1999) Regional differences in waiting time to pregnancy: pregnancy-based surveys from Denmark, France, Germany, Italy and Sweden. Hum Reprod $14,1250-1254$.

14. Jung JH, Seo JT (2014) Empirical medical therapy in idiopathic male infertility: promise or panacea? Clin Exp Reprod Med 41, 108-114.

15. Bieniek KW, Riedel HH (1993) Bacterial foci in the teeth, oral cavity, and jaw--secondary effects (remote action) of bacterial colonies with respect to bacteriospermia and subfertility in males. Andrologia 25, 159-162.

16. Klinger A, Hain B, Yaffe H, Schonberger O (2011) Periodontal status of males attending an in vitro fertilization clinic. J Clin Periodontol 38, 542-546.

17. World Health Organization (2010) WHO laboratory manual for the examination and processing of human semen. 5th ed, WHO Press, Geneve.

18. Ramfjord SP (1959) Indices for prevalence and incidence of periodontal disease. J Periodontol 30, 51-59.

19. Silness J, Löe H (1964) Periodontal disease in pregnancy. II. Correlation between oral hygiene and periodontal condition. Acta Odontol Scand 22, 121-135.

20. Nwhator SO, Umeizudike KA, Ayanbadejo PO, Opeodu OI, Olamijulo JA, Sorsa T (2014) Another reason for impeccable oral hygiene: oral hygiene-sperm count link. J Contemp Dent Pract 15, 352-358.

21. Amann RP (2008) The cycle of the seminiferous epithelium in humans: a need to revisit? J Androl 29, 469-487.

22. Armitage GC, Research, Science and Therapy Committee of the American Academy of Periodontology (2003) Diagnosis of periodontal diseases. J Periodontol 74, 1237-1247.

23. Lang NP, Joss A, Orsanic T, Gusberti FA, Siegrist BE (1986) Bleeding on probing. A predictor for the progression of periodontal disease? J Clin Periodontol 13, 590-596.

24. Lang NP, Tonetti MS (2003) Periodontal risk assessment (PRA) for patients in supportive periodontal therapy (SPT). Oral Health Prev Dent 1, 7-16.

25. Radnai M, Pál A, Novák T, Urbán E, Eller J, Gorzó I (2009) Benefits of periodontal therapy when preterm birth threatens. J Dent Res 88, 280-284.

26. Lindhe J, Socransky SS, Nyman S, Haffajee AD, Westfelt E (1982) "Critical probing depth" in periodontal therapy. J Clin Periodontol 9, 323-336. 
27. Listgarten MA (1980) Periodontal probing: what does it mean? J Clin Periodontol 7, 165-176.

28. Löe H, Anerud A, Boysen H, Morrison E (1986) Natural history of periodontal disease in man. Rapid, moderate and no loss of attachment in Sri Lankan laborers 14 to 46 years of age. J Clin Periodontol 13, 431-445.

29. Mumghamba EG, Pitiphat W, Matee MI, Simon E, Merchant AT (2004) The usefulness of using Ramfjord teeth in predicting periodontal status of a Tanzanian adult population. J Clin Periodontol 31, 16-18.

30. Chrysanthakopoulos NA (2015) Risk factors for the progression of periodontal disease in a Greek adult population. J Investig Clin Dent doi: 10.1111/jicd.12199.

31. Richthoff J, Elzanaty S, Rylander L, Hagmar L, Giwercman A (2008) Association between tobacco exposure and reproductive parameters in adolescent males. Int J Androl 31, 31-39.

32. Lingappa HA, Govindashetty AM, Puttaveerachary AK, Manchaiah S, Krishnamurthy A, Bashir S et al. (2015) Evaluation of effect of cigarette smoking on vital seminal parameters which influence fertility. J Clin Diagn Res 9, EC13-15.

33. Potts RJ, Newbury CJ, Smith G, Notarianni LJ, Jefferies TM (1999) Sperm chromatin damage associated with male smoking. Mutat Res 423, 103-111.

34. Chambrone L, Preshaw PM, Rosa EF, Heasman PA, Romito GA, Pannuti CM et al. (2013) Effects of smoking cessation on the outcomes of non-surgical periodontal therapy: a systematic review and individual patient data meta-analysis. J Clin Periodontol 40, 607-615.

35. Santos EP, López-Costa S, Chenlo P, Pugliese MN, Curi S, Ariagno J et al. (2011) Impact of spontaneous smoking cessation on sperm quality: case report. Andrologia 43, 431-435.

36. Domes T, Lo KC, Grober ED, Mullen JB, Mazzulli T, Jarvi K (2012) The incidence and effect of bacteriospermia and elevated seminal leukocytes on semen parameters. Fertil Steril 97, 1050-1055.

37. Cullinan MP, Seymour GJ (2013) Periodontal disease and systemic illness: will the evidence ever be enough? Periodontol 2000 62, 271-286.

38. Noack B, Genco RJ, Trevisan M, Grossi S, Zambon JJ, De Nardin E (2001) Periodontal infections contribute to elevated systemic C-reactive protein level. J Periodontol 72, 12211227.

39. Paraskevas S, Huizinga JD, Loos BG (2008) A systematic review and meta-analyses on C-reactive protein in relation to periodontitis. J Clin Periodontol 35, 277-290.

40. Xia W, Wong EW, Mruk DD, Cheng CY (2009) TGF- $\beta 3$ and TNF- $\alpha$ perturb blood-testis barrier (BTB) dynamics by accelerating the clathrin-mediated endocytosis of integral membrane proteins: a new concept of BTB regulation during spermatogenesis. Dev Biol 327, 48-61.

41. Schell C, Albrecht M, Mayer C, Schwarzer JU, Frungieri MB, Mayerhofer A (2008) Exploring human testicular peritubular cells: identification of secretory products and regulation by tumor necrosis factor-alpha. Endocrinology 149, 1678-1686.

42. Zhang H, Yin Y, Wang G, Liu Z, Liu L, Sun F (2014) Interleukin-6 disrupts blood-testis barrier through inhibiting protein degradation or activating phosphorylated ERK in Sertoli cells. Sci Rep 4, 4260.

43. Eberhard J, Grote K, Luchtefeld M, Heuer W, Schuett H, Divchev D et al. (2013) Experimental gingivitis induces systemic inflammatory markers in young healthy individuals: a single-subject interventional study. PLoS One 8, e55265.

44. Kinane DF, Zhang P, Benakanakere M, Singleton J, Biesbrock A, Nonnenmacher C, He T (2015) Experimental gingivitis, bacteremia and systemic biomarkers: a randomized clinical trial. J Periodont Res 50, 864-869. 


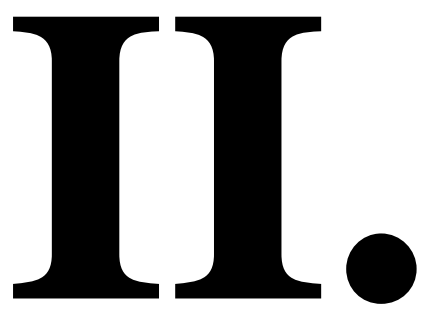




\title{
Caries and ABO Secretor Status in a Hungarian Population of Children and Adolescents: An Exploratory Study
}

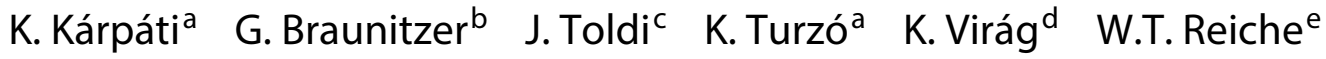 \\ Z. Rakonczay ${ }^{a}$ K. Nagy ${ }^{b}$ \\ a Department of Prosthodontics and Oral Biology and ${ }^{b}$ Department of Oral Surgery, Faculty of Dentistry, \\ 'Department of Transfusiology and d Department of Medical Physics and Informatics, Faculty of Medicine, \\ University of Szeged, Szeged, Hungary; ${ }^{~}$ Reiche und Partner Zahnmedizinisches Kompetenzzentrum, Wolfsburg, \\ Deutschland
}

\section{Key Words}

dmf-t/DMF-T · Mixed dentition · Salivary H-antigen

secretion

\begin{abstract}
$A B O$ blood group antigen ( $A B G A$ ) secretion into the saliva and other body fluids is a well-known phenomenon, and there is evidence to suggest a link between secretor status and the appearance of caries. It has been proposed that secretion of these antigens into the saliva might be caries-preventive, however, this proposition is still a matter of debate. Our aim was to examine the relationship between caries experience and secretor status in a group of Hungarian children and adolescents in a cross-sectional study. Altogether 130 children and adolescents participated in the study (aged 6-18 years). Participants were divided into two groups according to dentition (i.e. mixed and permanent). ABGA were determined from saliva. The DMF-T and dmf-t (decayed, missing, and filled) indices were calculated, as well as the oral health hygiene index-simplified plaque index. Association of these indices with secretor status was examined. In mixed dentition, the mean dmf-t values were significantly lower in the secretor group $(2.1 \pm 0.52 \mathrm{SEM})$, as compared to the non-
\end{abstract}

secretor group (3.8 \pm 0.93 SEM; $p<0.05$, Mann-Whitney $U$ test). The finding that children of mixed dentition are apparently better protected against caries suggests that the assumed protective effect might be associated with deciduous teeth, but given the general paucity of knowledge about this topic, further research is indicated.

(c) 2014 S. Karger AG, Basel

$\mathrm{ABO}$ blood group antigens (ABGA) are an integral part of the red cell membrane, and are also expressed into the body fluids. The ABO system, discovered by Landsteiner [1901] in 1901, is based on the modifications of the $\mathrm{H}$ antigen, a carbohydrate sequence, which, when present on the surface of erythrocytes in its unmodified form, codes the $\mathrm{O}$ type. The $\mathrm{A}, \mathrm{B}$ and $\mathrm{AB}$ types are coded by addition of $\alpha-\mathrm{N}$-acetylgalactosamine and $\alpha-\mathrm{D}-$ galactose to the $\mathrm{H}$ chain [Takizawa et al., 2000]. About $70-80 \%$ of the population secretes ABGA in the saliva and other body fluids where these antigens are bound primarily to mucins [Wolf and Taylor, 1964; Arneberg et al., 1976; Vidas et al., 1999]. Based on whether an individual secretes ABGA into body fluids, secretors and nonsecretors are differentiated between, which is defined

\section{KARGER}

E-Mail karger@karger.com

www.karger.com/cre
(C) 2014 S. Karger AG, Basel

0008-6568/14/0483-0179\$39.50/0
Krisztina Kárpáti, DDS

Department of Prosthodontics and Oral Biology

Faculty of Dentistry, University of Szeged

HU-6720 Szeged Tisza Lajos krt. 64 (Hungary)

E-Mailkarpatik@stoma.szote.u-szeged.hu 
as secretor status. The secretor status depends on which alleles for the Lewis antigen system the individual carries, that is, an individual carrying the dominant Le and Se alleles will be a secretor [Grubb, 1948; Simmons et al., 1951]. The percentage of secretors in Caucasian populations has been approximated at $80 \%$ [Wolf and Taylor, 1964]. As pointed out by Vidas et al. [1999], the secretor status of a patient may possibly be a factor influencing the development of systemic oral disease. According to Demir et al. [2007], the ABO blood subgroups and the $\mathrm{Rh}$ factor may constitute a risk factor in the development of periodontal diseases. The authors found a relatively higher percentage of A group patients in their gingivitis group and a relatively higher percentage of $O$ group patients in their periodontitis group. Other studies reached different conclusions. For instance, it was found that the prevalence of vaginal candidiasis was significantly higher in nonsecretors [Kulkarni and Venkatesh, 2004]. McGovern et al. [2010] found the fucosyltransferase 2 nonsecretor status to be associated with Crohn's disease. Sakamoto et al. [1976] found no association between DMF (decayed, missing, and filled teeth) scores and either $\beta$-glucuronidase inhibitor activity or secretor status. A seminal Icelandic study suggested that blood group antigens may interfere with the adherence of Streptococcus mutans to teeth, thereby having a preventive effect against caries [Holbrook and Blackwell, 1989]. Still other studies revealed a connection between certain diseases and secretor status, including myocardial infarction [Nydegger et al., 2003], transitional cell carcinoma of the bladder [Chihara et al., 2005] and pancreatic cancer [Risch, 2012]. The aim of the present study was to investigate the hypothesized effect of ABGA expression into saliva on caries in a group of Hungarian children and adolescents. The primary aim was to examine if caries experience might be associated with secretor status in this population. It is important to emphasize that this study - to our knowledge the first to address this specific issue - was designed as exploratory, and therefore results are to be interpreted as preliminary.

\section{Materials and Methods}

\section{Study Population}

The study was carried out at the dentistry clinic of the Faculty of Dentistry of the University of Szeged in 2011. A sample of 130 healthy schoolchildren (children and adolescents aged between 6 and 18 years, $\left.\mathrm{n}_{\text {male }}=60, \mathrm{n}_{\text {female }}=70\right)$ present for an annually organized screening participated in this study. The sample size was determined by the turnup rate (annual screening is not mandatory in Hungary), willingness to participate, and the exclusion criteria. Only healthy subjects with no known oral or systemic disease were eligible for the study. Taking any kind of medication per os at the time of saliva sampling was also an exclusion criterion. However, to assure that the resulting sample size yielded statistically meaningful results, a post hoc power analysis was conducted (see 'Results'). The participants were all Caucasian of a homogeneous socioeconomic background. The study protocol conformed to the tenets of the Declaration of Helsinki in all respects, and it was approved by the Ethical Board of the University of Szeged. Participants and their parents were provided information regarding the goals, risks and the procedures involved in the study in both oral and written form. Upon receiving this information, the parents of the participants were asked to give their consent to the participation of their children by signing an informed consent form.

\section{Caries Experience and Oral Hygiene}

Data for the calculation of $\mathrm{dmf}-\mathrm{t} / \mathrm{DMF}-\mathrm{T}$ were collected as part of a routine dental status assessment. Caries experience was assessed by calculating the dmf-t/DMF-T scores according to the WHO criteria. A tooth with more than one carious lesion was scored as one decayed tooth; a tooth with a filling and a separate carious lesion was scored as one filled tooth. The simplified oral health hygiene index (OHI-S) was also calculated [Greene and Vermillion, 1964]. These calculations were carried out prior to secretor status determination, therefore, the dentist performing the assessment was blind to subjects' secretor status.

\section{Secretor Status and ABO Blood Group Determination}

Secretor status was determined along the lines described in Vidas et al. [1999]. Unstimulated whole saliva (3-4 ml) was collected from each subject. Saliva collection took place either in the morning hours or early in the afternoon, but at least $2 \mathrm{~h}$ after the last meal or toothbrushing. Saliva was collected in test tubes. A glass funnel with a piece of absorbent paper inside it was inserted into the test tube, and participants were asked to spit into the funnel 1 or 2 times per minute. Using this procedure it was possible to collect an average of 3-4 $\mathrm{ml}$ of saliva. The absorbent paper inside the funnel served to filter contaminants.

Samples collected this way were sealed and placed in boiling water for 10-20 min to inactivate the enzymes. Samples were then centrifuged at 3,000 rpm for $5 \mathrm{~min}$ and the supernatant was separated and analyzed for ABGA (the saliva samples were either processed immediately or stored at $-80^{\circ} \mathrm{C}$ until use) by a hemagglutination inhibition test with appropriate antisera (Blood Grouping Test Reagents Anti-A, Anti-B, Anti-H, Sifin ${ }^{\circledR}$ Berlin, Germany; ALBA clone Anti-A, Anti-B, Anti-H Blood Grouping Reagents, Alba Bioscience ${ }^{\circledR}$, Edinburgh, United Kingdom). A plate hemagglutination-inhibition test was employed in the following manner: the saliva samples were diluted in a ratio of $1: 2$, while A-, B-, and $\mathrm{H}$-antisera were diluted in a ratio of 1:8. Sterile distilled water was used for dilution. The diluted saliva samples and antisera were then mixed in test tubes and stored in a wet chamber for $10 \mathrm{~min}$. After the incubation period, 1-2 drops of 2-3\% erythrocyte solution were added to each, and the result was recorded. The hemagglutination reaction indicated a lack of $\mathrm{ABO}$ antigen production, and a reaction not taking place revealed the presence of antigens in the saliva samples, as in the latter case the antigen-antibody complexes were already formed when the proper antiserum was added to the saliva sample. In the case of nonsecretors no reaction was seen. 
Table 1. Descriptive statistics of the sample

Gender Mean age, Mean OHI-S Mean dmf-t Type A, \% Type B, \% Type AB, \% Type O, \% ratio F:M years (range) (range) (range)

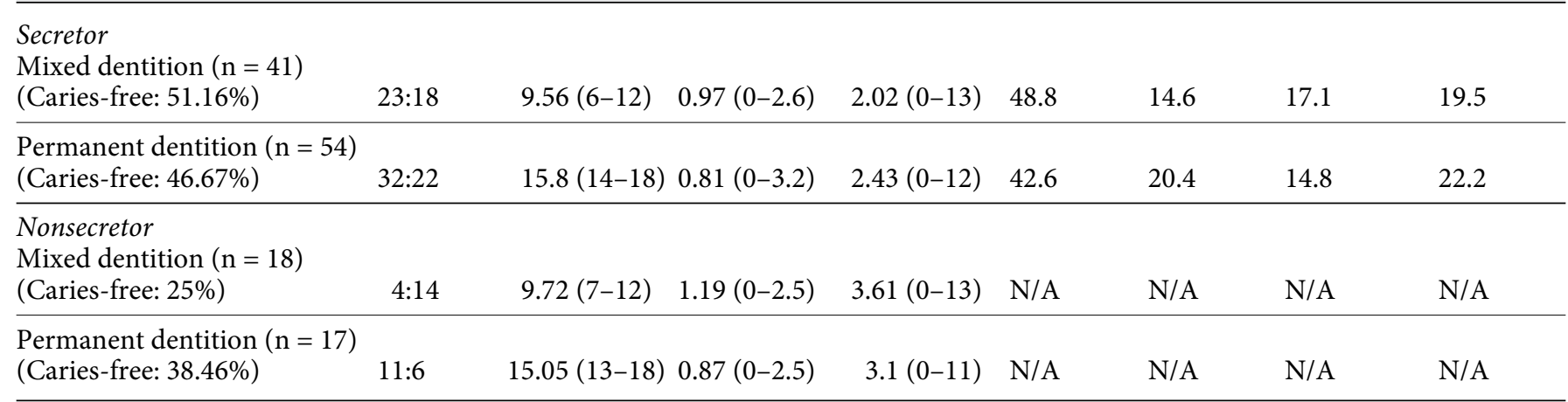

N/A = Not applicable.

\section{Statistical Analysis}

The study population was divided into two groups on the basis of dentition (i.e. mixed or permanent), within which secretor and nonsecretor subgroups were determined. Data analysis was conducted on the basis of this grouping. The mixed dentition group had both deciduous and permanent teeth, the permanent dentition group had permanent teeth only.

Data were analyzed using SPSS 17.0 software. As our data did not fulfill the normal distribution criterion, we used the nonparametric Mann-Whitney U (MWU) test for between-group comparisons. To determine the degree of association between dmf- $t$ / DMF-T and OHI-S, the $\chi^{2}$ test was used. Wherever our dataset violated the assumption of the $\chi^{2}$ test (i.e. expected frequencies of at least five), we used Fisher's exact test. The level of significance was $\mathrm{p}<0.05$. Post hoc power analysis for the $\mathrm{dmf} / \mathrm{DMF}$ comparisons was conducted in $\mathrm{G}^{*}$ Power (Universität Kiel, Germany).

\section{Results}

\section{Basic Statistics}

Data were analyzed by dentition type and secretor status. Of the 130 subjects, 95 (73\%) turned out to be secretors, of which 54 (56.8\%) had permanent dentition (mean age: 15.63 years; range: $14-18$ years) and $41(43.2 \%)$ had mixed dentition (mean age: 9.86 years; range: $6-13$ years). Of the 35 (26.9\%) nonsecretors 17 (48.6\%) had permanent dentition and 18 (51.4\%) had mixed dentition. In both dentition types approximately $40 \%$ of the subjects were caries-free (defined as dmf-t/DMF-T $=0$ ), however, the ratios differed considerably by secretor status (table 1). The ratio of secretors to nonsecretors was in accordance with previously published data (see introduction). ABO antigen distribution in secretors was also determined from the 130 samples of saliva. The distribution for the whole examined secretor population was as follows: A 44.2\%, B 16.8\%, AB 15.8\%, O 23.2\%. Detailed basic statistics by dentition and secretor status are given in table 1.

\section{Association between OHI-S and dmf-t/DMF-T}

The association between OHI-S and dmf-t in mixed dentition was not significant, while between OHI-S and DMF-T in permanent dentition significant association was found: $\chi^{2}(252, \mathrm{n}=71)=346.93, \mathrm{p}=0.000$.

\section{Comparison of DMF-T/dmf-t between Secretors and Nonsecretors}

There was no statistically significant difference in DMF-T status between secretors and nonsecretors in permanent dentition $\left(\mathrm{n}_{1}=17, \mathrm{n}_{2}=54, \mathrm{U}=454.5, \mathrm{p}=0.952\right.$, MWU). However, statistically significant difference was found in dmf-t between secretor and nonsecretor statuses in mixed dentition $\left(\mathrm{n}_{1}=18, \mathrm{n}_{2}=41, \mathrm{U}=234, \mathrm{p}<0.05\right.$, MWU). Post hoc power analysis revealed a high statistical power: $1-\beta=0.89(d=0.5, \alpha=0.05)$. To determine if this effect was linked to any particular secreted antigen, association between dmf- $t$ and antigen types was computed, but no significant association was found: $\chi^{2}(30, \mathrm{n}=41)=$ $23.16, \mathrm{p}=0.809$. A graphical representation of the comparisons is given in figure 1 . In particular, the mean $( \pm S D)$ dmf-t values in mixed dentition were significantly lower in the secretor group $(2.1 \pm 3.46)$ compared to the nonsecretor group $(3.8 \pm 3.94)$. When only dentition types were compared, without taking secretor status into account, this difference disappeared $(2.60 \pm 3.76,2.59 \pm 3.13$, mixed and permanent, respectively; mean $\pm \mathrm{SD})$. 


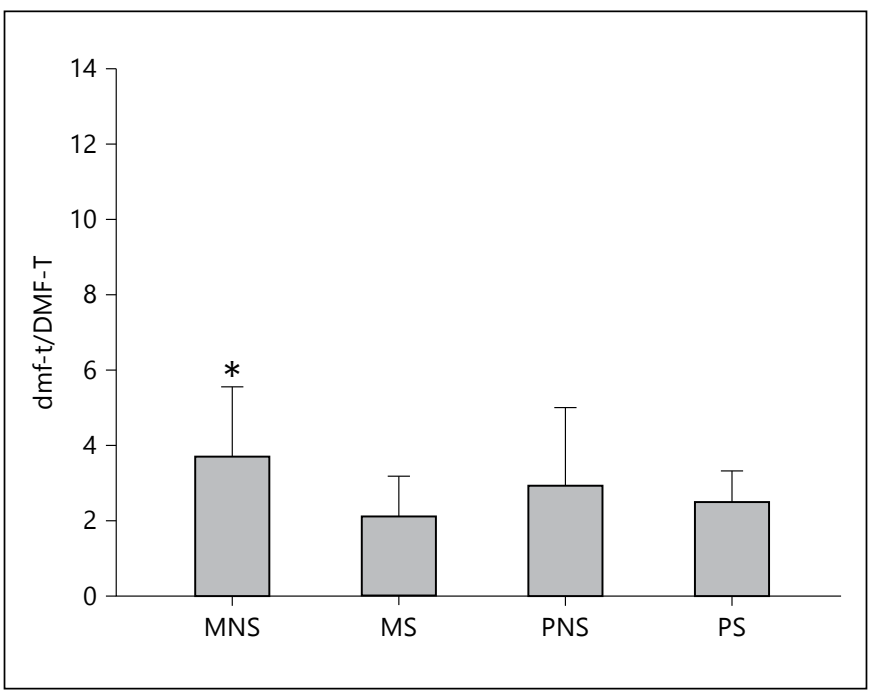

Fig. 1. Comparison of dmf-t/DMF-T by dentition type and secretor status. MNS = Mixed, nonsecretor; MS = mixed, secretor; PNS = permanent, nonsecretor; PS = permanent, secretor. Bars denote means, whiskers mark 95\% CI. Significant difference: ${ }^{*} \mathrm{p}<$ 0.05. For details see 'Results'.

\section{Sex Differences}

Significant sex difference was found only in the mixed dentition group $\left(\mathrm{n}_{1}=33, \mathrm{n}_{2}=30, \mathrm{U}=322, \mathrm{p}=0.017\right.$, $\mathrm{MWU}$ ). This means that at an average, girls between 6 and 12 years exhibited better oral hygiene as measurable by OHI-S than boys of the same cohort (mean OHI-S 0.83 vs. 1.21, respectively). In the permanent dentition group no such difference was seen $\left(\mathrm{n}_{1}=27, \mathrm{n}_{2}=40, \mathrm{U}=393, \mathrm{p}=\right.$ $0.061, \mathrm{MWU})$. The association between sex and secretor status in mixed dentition was significant $(\mathrm{p}=0.000$, Fisher's exact test), while in permanent dentition no significant association was found ( $\mathrm{p}=0.458$, Fisher's exact test). To verify that the DMF-T/dmf-t comparisons were not influenced by different oral hygiene as related to sex, we also compared OHI-S between the sex subgroups of the secretor/nonsecretor groups. No significant difference was found for either sex (secretors vs. nonsecretors, girls: $\mathrm{n}_{1}=54, \mathrm{n}_{2}=15, \mathrm{U}=397, \mathrm{p}=0.914$, MWU; boys: $\mathrm{n}_{1}=39$, $\left.\mathrm{n}_{2}=20, \mathrm{U}=345, \mathrm{p}=0.479, \mathrm{MWU}\right)$.

\section{Discussion}

Although association has been suggested with a number of diseases, a relatively small number of studies dealt with the possible association between $\mathrm{ABO}$ secretor status and dental caries in humans, especially in children and adolescents. Whether $\mathrm{ABO}$ secretor status influences dental caries is yet to be determined.

Mavridis and Achimastos [1974] found higher mean DMF-T in secretors, the difference, however, was not significant. Barros and Witkop [1963] found no relation between DMF-T and $\mathrm{ABO}$ and $\mathrm{MN}$ blood groups in a large Chilean population, while Arneberg et al. [1976] found lower caries prevalence for secretors, regardless of blood group, with a more pronounced difference for smooth surfaces (i.e. oral or vestibular tooth surfaces). Studying a population of young Icelanders, Holbrook and Blackwell [1989] found significantly lower DMF in secretors than nonsecretors. The authors suggested that blood group antigens may interfere with the adherence of $S$. mutans to teeth [Holbrook and Blackwell, 1989]. It is to be noted that in Iceland the proportion of nonsecretors is among the highest recorded in Europe [Eriksson et al., 1986], and the prevalence of caries, especially in childhood, is accordingly high [Agustsdottir et al., 2010], which seems to be a strong argument for the protective role of $\mathrm{ABO}$ secretion. Still other studies [Green et al., 1966; Achimastos et al., 1974] failed to confirm an association of caries experience and $\mathrm{ABO}$ secretion.

Our present study, in which we examined a sample of 130 children and adolescents in order to identify if an association exists between caries experience and secretor status, might be regarded as an addition to this debate.

The only significant, secretor status-related difference was found in dmf-t which was significantly higher in nonsecretors, which is the main finding of our study. Significant sex difference was also found in oral hygiene in the mixed dentition group, however, no association was found between dmf-t/DMF-T and OHI-S in either group.

This latter result, counterintuitive as it may seem, is not problematic, because oral hygiene per se is obviously not the only factor influencing caries formation. We assume that OHI-S may be a sensitive predictor of caries status only in poor oral hygiene. Matulaitiene et al. [2012] examined oral health indices of Lithuanian schoolchildren of average to good oral hygiene, and reported that while dmf-t/DMF-T decreased significantly in the studied period (1983-2009), OHI-S did not reflect this change.

The significant sex difference in the younger (mixed dentition) group is also understandable, in light of the superiority of girls over boys in terms of oral hygiene in this cohort [Al Dosari et al., 2000; Kolawole et al., 2011]. The explanation of this, however, is beyond the scope of this article.

The main finding of our study, that is, that $\mathrm{ABO}$ secretors of mixed dentition exhibit lower caries experience, is 
rather difficult to explain at the present level of our knowledge, especially considering that studies focusing on $\mathrm{ABO}$ secretion and caries in children are limited. Our results definitely show that this effect is associated with mixed dentition, that is, the presence of primary teeth. Considering that primary teeth are more caries-prone due to the lower mineral content of their enamel layer [Wilson and Beynon, 1989], their morphology [Sabel, 2012], and narrow interdental spaces [Warren et al., 2003], it might be hypothesized that secretion of $\mathrm{ABO}$ antigens into the saliva may provide some sort of extra protection to primary teeth. In this respect it is important to note that tooth surface was found to be a significant factor in another study dealing with secretor status and caries experience too [Arneberg et al., 1976]. Our findings, of course, and especially in view of the Icelandic sample [Holbrook and Blackwell, 1989], do not necessarily imply that the hypothesized preventive effect is completely missing in adulthood. We would argue, rather, that it is more remarkable when the more vulnerable deciduous teeth are still present.

The exploratory nature of this study naturally raises the issue of whether the observed effect could be due to some uncontrolled background variable, such as dietary or oral hygiene differences between the cohorts. No direct measurements were done to address such variables, obviously a limitation of the study. However, the fact that the significant dmf-t/DMFT difference between the dentition types was seen only when secretor status was considered as an influencing factor, seems not to support such a scenario. Furthermore, no significant difference in $\mathrm{OHI}-\mathrm{S}$ as a measure of oral hygiene was found between the dentition type-based cohorts (mixed: $2.59 \pm 3.67$, permanent: $2.60 \pm 3.13$; mean $\pm S D$ ), which makes it quite unlikely that significant changes of oral hygiene habits occurred with age.

As the influence of secretor status on caries experience has been paid surprisingly little attention since the 1970 s when the subject was first mentioned, the exact protective mechanism remains unknown. Based on the available literature it is possible to set up a reasonable explanatory framework, however, it must be noted that this framework - due to the paucity of research into these mechanisms - can only be speculative in nature. Our proposed explanation focuses on salivary glycoproteins (mucins) and their role in bacterial attachment.

As a starting point we hypothesize that the observed protective effect is due to $\mathrm{ABO}$ antigens' interference with the attachment of cariogenic bacteria to the surface of the teeth. This hypothesis was articulated earlier [Holbrook

Salivary ABO Secretion and Caries in Children and Blackwell, 1989] in connection with S. mutans, but the authors did not put it in detail. It must be also noted that several other species have been shown to play a role in caries formation and progression [Aas et al., 2008].

Williams and Gibbons [1975] observed that mucinous glycoproteins could aggregate certain bacterial species and prevent them from attachment to the buccal epithelium. The authors suggested that this was possible through a kind of molecular mimicry, that is, mucinous glycoproteins possessed antigenic determinants in common with a wide range of body cells (including those of the buccal epithelium), and it was these antigenic determinants by which the glycoproteins could aggregate bacteria. More importantly, it was also shown that pretreatment of epithelial cells from a donor of A blood type with A antiserum prevented the attachment of Streptococcus sanguis to these cells. This finding supported the theory that blood group antigens could establish a link between bacteria and the surface on which they are located. However, the study focused on the buccal epithelium, not the solid hydroxyapatite surface of teeth, and no testing was done to find out about if mucin donors were secretors or not, so the results are best interpreted as characterizing salivary mucins in general. The key finding of the study, therefore, is possibly that salivary mucins are able to aggregate bacteria, which, however, is not a really promising finding in terms of caries protection.

Mucins are crucial components of the acquired enamel pellicle without which bacteria could not colonize tooth surfaces and form a complex biofilm, the metabolic processes of which lead to caries, gingivitis and periodontitis. The acquired pellicle is composed of a variety of salivary glycoproteins and antibodies. This film alters the characteristics of the surface, which in turn increases the efficiency of bacterial adhesion [Lang et al., 2008]. That is, the aggregation of bacteria by mucins in the enamel pellicle is a pro-caries process, and therefore it cannot account for the protection observed in $\mathrm{ABO}$ secretors. How then do mucins play a role in protection? $\mathrm{ABO}$ antigen determinants in secretors are located at the terminal part of the carbohydrate side chain in glycoproteins of the mucin type [Marcus, 1969]. In other words, the mucins of secretors are structurally different. We hypothesize that this structural difference might play a key role in the protective effect. Bacteria invade the pellicle-coated enamel surface as primary and secondary colonizers. Primary colonizers (like $S$. mutans) attach directly to the glycoproteins of the acquired pellicle, while secondary colonizers attach to the primary ones [Lang et al., 2008]. On such premises we suggest that two explanations are possible. 
One is that the structural difference of the mucins of secretors deteriorates their ability to aggregate cariogenic bacteria. The finding that pretreatment of mucins with anti-ABO antisera did not influence their ability to aggregate Streptococcus miteor [Williams and Gibbons, 1975] might be a counterargument here, but by no means an unquestionable one, as the secretor status of mucin donors was not known, and the effect was found to be species-dependent, even at a very low number of studied species (S. miteor, S. sanguis and Streptococcus salivarius). This latter finding suggests high interspecies variability. The other explanation may be that structurally altered (secretor) mucins do not adhere so readily and stable to the enamel surface as nonsecretor mucins, therefore, they cannot serve as a firm base for colonization. In any of these two scenarios, part of the maximal adhesive surface would be lost, and colonization would be less efficient. This would mean much better but still not perfect caries resistance, as there are several known cariogenic species, and, as mentioned before, the effect appears to be speciesdependent. The results of this study and those of other studies suggesting that secretors are better protected but not completely caries-free correspond to such a scenario.
To our knowledge, this is the first study to address the relationship between secretor status and caries experience in school-age children by dentition type. Our results corroborate other studies that found $\mathrm{ABO}$ antigen secretion protective against caries. What is novel about these results is that they raise the possibility that salivary $\mathrm{ABO}$ secretion might play a role in the protection of primary teeth, but to confirm this finding further research is necessary, especially regarding the background mechanisms.

\section{Acknowledgments}

This study was supported by ETT 248/2009, funded by the Hungarian Ministry of Health to Principal Investigator Z.R. The authors thank Mrs. Aladárné Pintér for her technical assistance. The authors are especially grateful to Prof. Dr. Michele Shedlin of the New York University School of Nursing for her assistance with the language editing.

\section{Disclosure Statement}

The authors declare no conflict of interest.

\section{References}

-Aas JA, Griffen AL, Dardis SR, Lee AM, Olsen I, Dewhirst FE, Leys EJ, Paster BJ: Bacteria of dental caries in primary and permanent teeth in children and young adults. J Clin Microbiol 2008;46:1407-1417.

Achimastos A, Mavridis N, Hatjiotis J: Blood groups and dental caries experience in man. J Dent Res 1974;53:1300.

-Agustsdottir H, Gudmundsdottir H, Eggertsson $\mathrm{H}$, Jonsson SH, Gudlaugsson JO, Saemundsson SR, et al: Caries prevalence of permanent teeth: a national survey of children in Iceland using ICDAS. Community Dent Oral Epidemiol 2010;38:299-309.

Al Dosari AM, Abdellatif H, Al Refai AN: Oral health status of primary dentition among 551 children aged 6 to 8 years in Jazan, Saudi Arabia. Saudi Dent J 2000;12:67-71.

-Arneberg P, Kornstad L, Nordbo H, Gjermo P: Less dental caries among secretors than among non-secretors of blood group substance. Scand J Dent Res 1976;84:362-366.

- Barros L, Witkop CJ Jr: Oral and genetic study of Chileans 1960. III. Periodontal disease and nutritional factors. Arch Oral Biol 1963;8: 195-206.

Chihara Y, Sugano K, Kobayashi A, Kanai Y, Yamamoto H, Nakazono M, et al: Loss of blood group A antigen expression in bladder cancer caused by allelic loss and/or methylation of the ABO gene. Lab Invest 2005;85:895907.

Demir T, Tezel A, Orbak R, Eltas A, Kara C, Kavrut F: The effect of $\mathrm{ABO}$ blood types on periodontal status. Eur J Dent 2007;1:139-143.

Eriksson AW, Partanen K, Frants RR, Pronk JC, Kostense PJ: $\mathrm{ABH}$ secretion polymorphism in Icelanders, Aland Islanders, Finns, Finnish Lapps, Komi and Greenland Eskimos: a review and new data. Ann Hum Biol 1986;13: 273-285.

Green GE, Wilson RM, Freeman NC: Human blood types and dental caries experience. J Dent Res 1966;45:1818.

Greene JC, Vermillion JR: The simplified oral hygiene index. J Am Dent Assoc 1964;68:7-13.

Grubb R: Correlation between Lewis blood group and secretor character in man. Nature 1948; 162:933.

Holbrook WP, Blackwell CC: Secretor status and dental caries in Iceland. FEMS Microbiol Immunol 1989;1:397-399.

Kolawole KA, Oziegbe EO, Bamise CT: Oral hygiene measures and the periodontal status of school children. Int J Dent Hyg 2011;9:143148.

Kulkarni DG, Venkatesh D: Non-secretor status: a predisposing factor for vaginal candidiasis. Indian J Physiol Pharmacol 2004;48:225229.
Landsteiner K: Zur Kenntnis der antifermentativen, lytischen und agglutinierenden Wirkungen des Blutserums und der Lymphe. Zentralbl Bakteriol Parasitenkd Infektionskr 1901;27:357-362.

Lang NM, Mombelli A, Attström R: Oral biofilm and calculus; in Lindhe J (ed): Periodontology and Implant Dentistry. Copenhagen, Blackwell Munksgaard, 2008, pp 183-206.

Marcus DM: The ABO and Lewis blood-group system: immunochemistry, genetics and relation to human disease. N Engl J Med 1969; 280:994-1006.

Matulaitiene ZK, Zemaitiene M, Zemgulyte S, Milciuviene S: Changes in dental caries and oral hygiene among 7-8 year-old schoolchildren in different regions of Lithuania 19832009. Stomatologija 2012;14:53-59.

Mavridis N, Achimastos A: Secretor status and dental caries. J Dent Res 1974;53:949.

McGovern DP, Jones MR, Taylor KD, Marciante $\mathrm{K}$, Yan X, Dubinsky M, et al: Fucosyltransferase 2 (FUT2) non-secretor status is associated with Crohn's disease. Hum Mol Genet 2010; 19:3468-3476.

Nydegger UE, Wuillemin WA, Julmy F, Meyer BJ, Carrel TP: Association of ABO histo-blood group $B$ allele with myocardial infarction. Eur J Immunogenet 2003;30:201-206. 
Risch HA: Pancreatic cancer: Helicobacter pylori colonization, $\mathrm{N}$-nitrosamine exposures, and ABO blood group. Mol Carcinog 2012;51: 109-118.

-Sabel N: Enamel of primary teeth - morphological and chemical aspects. Swed Dent J Suppl 2012;222:1-77.

Sakamoto W, Nishikaze O, Sugimura T: betaGlucuronidase inhibitor-activity in human saliva and its relation to dental caries, secretor status and blood group. Arch Oral Biol 1976; 21:761-763.
Simmons RT, Semple NM, Graydon JJ: The Lewis (Lea) blood group and secretor types: a review; their correlation in the blood and saliva of white Australians. Med J Aust 1951;1:105110.

Takizawa H, Kominato Y, Shimada I: Progress in the study of $\mathrm{ABO}$ blood group system. Leg Med (Tokyo) 2000;2:1-6.

Vidas I, Delajlija M, Temmer-Vuksan B, StipeticMravak M, Cindric N, Maricic D: Examining the secretor status in the saliva of patients with oral pre-cancerous lesions. J Oral Rehabil 1999;26:177-182.

-Warren JJ, Slayton RL, Yonezu T, Kanellis MJ, Levy SM: Interdental spacing and caries in the primary dentition. Pediatr Dent 2003;25:109_ 113.
Williams RC, Gibbons RJ: Inhibition of streptococcal attachment to receptors on human buccal epithelial cells by antigenically similar salivary glycoproteins. Infect Immun 1975; 11:711-718.

Wilson PR, Beynon AD: Mineralization differences between human deciduous and permanent enamel measured by quantitative microradiography. Arch Oral Biol 1989;34:85-88.

Wolf RO, Taylor LL: The concentration of bloodgroup substance in the parotid, sublingual, and submaxillary salivas. J Dent Res 1964;43: 272-275. 